Klaus Denecke Rabello

\title{
"Selbstliebe na obra de Kant - para além da disposição original para o bem ou fonte de todo mau, progresso
} moral"

Dissertação apresentada como requisito parcial para obtenção do grau de Mestre pelo Programa de Pósgraduação em Filosofia de Departamento de Filosofia da PUC-Rio.

Orientadora: Prof. ${ }^{\text {a }}$ Vera Cristina de Andrade Bueno 
Klaus Denecke Rabello

\section{"Selbstliebe na obra de Kant - para além da disposição original para o bem ou fonte de todo mau, progresso} moral"

Dissertação apresentada como requisito parcial para obtenção do grau de Mestre pelo Programa de Pós-graduação em Filosofia do Departamento de Filosofia do Centro de Teologia e Ciências Humanas da PUC-Rio. Aprovada pela Comissão Examinadora abaixo assinada.

\section{Prof. a Vera Cristina de Andrade Bueno \\ Orientadora \\ Departamento de Filosofia - PUC-Rio \\ Prof. Edgard José Jorge Filho \\ Departamento de Filosofia - PUC-Rio}

Prof. Fernando Augusto da Rocha Rodrigues Universidade Federal do Rio de Janeiro - UFRJ

Prof. - Denise Berruezo Portinari Coordenadora Setorial do Centro de Teologia e Ciências Humanas - PUC-Rio 
Todos os direitos reservados. É proibida a reprodução total ou Parcial do trabalho sem autorização da universidade, do autor e do orientador.

\section{Klaus Denecke Rabello}

Jornalista formado pela PUC-Rio, MBA/especialista em marketing pelo IAG/PUC-Rio, Pós-graduado em Filosofia pela FSB, Mestre em Filosofia pela PUC-Rio, Pós-graduando em Psicologia junguiana pela PUC-Rio. Consultor nas áreas de comunicação e marketing, com foco em soluções convergentes e sustentáveis. Palestrante e escritor. Consultor e proprietário da 2tag.net; 14 anos de docência em comunicação digital ( PUC-Rio, UniverCidade, ESPM e UVA). Fluente em alemão, português e inglês. Noções básicas de francês, espanhol, latim e tibetano.

Ficha Catalográfica

Rabello, Klaus Denecke

"Selbstliebe na obra de Kant - para além da disposição original para o bem ou fonte de todo mau, progresso moral" / Klaus Denecke Rabello; orientadora: Vera Cristina de Andrade Bueno. - 2014.

$96 \mathrm{f} . ; 30 \mathrm{~cm}$

Dissertação (mestrado)-Pontifícia Universidade Católica do Rio de Janeiro, Departamento de Filosofia, 2014.

Inclui bibliografia 
Ao meu Opa, Klaus Denecke, que com sua magna humildade e visão soberana, sempre inspirou meu caminho e aos meus 18 anos profetizou este momento. 


\section{Agradecimentos}

Meu avô, Klaus Denecke, sempre me ensinou a ser grato. E desde pequeno sou grato à vida simplesmente por existir e poder contemplar toda grandeza do universo mesmo no minúsculo cosmo que habita uma efêmera gota de orvalho. Sou grato pelos breves instantes da vida que vivi até aqui que me trouxeram eternos aprendizados. Sou grato a todos com quem interagi e aprendi ao longo de minha vida. Tudo o que sei é um mosaico do fragmento de interações ao qual busco honrar dando sentido.

Sou grato ao meu pai, Hugo Rabello Filho, por me incentivar a buscar segurança para edificar minha vida, por me estimular a perseguir meus objetivos. Sou-lhe grato por me dar a âncora que me põe os pés no chão e me ensina a caminhar na vida fenomênica. Sou-lhe grato por ser um exemplo prático de bondade, humildade, generosidade e competência no que faz. Quando crescer, quero ser que nem você, meu pai.

Sou grato à minha mãe, Eliane Denecke, por me incentivar a sonhar para edificar minha vida, por me estimular a esculpir meus sonhos. E a vive-los. Sou-lhe grato por me dar as asas que me levam a contemplar a vida por uma outra perspectiva, por me dar as cores para pintar minha alegria de viver. Sou-lhe grato por ser um exemplo prático de doação, de entrega, de sacrifício, de compaixão. Sou-lhe grato pelo exemplo da sincera busca por autoconhecimento, por me estimular a conhecer a mim mesmo, a me superar, a deter todo tipo de conhecimento sem preconceito. Por fim, sou-lhe grato por se importar em ajudar mesmo em meio a tudo que tem lhe acontecido, fazendo preciosa revisão.

Sou grato aos meus pais por terem me feito com amor. Eis a razão de eu estar aqui.

Sou grato ao meu amigo, Bernd Michel, que trouxe todos os livros da Alemanha sempre que solicitado e em tempo hábil para que eu pudesse ler todos na língua original, tendo sido também uma importante fonte para debater dúvidas a cerca da compreensão da língua.

Sou grato à minha namorada, Nana Polastri, que ajudou a transcrever citações de dois livros e que aguentou toda pressão e distância que um mestrado traz consigo. Sou-lhe grato por sermos um campo fértil na experiência do amor de si dentro do amor recíproco em meio a embates sobre o amor universal, o respeito e toda sorte de interações. Sou-lhe grato por tantas experiências e aprendizados que temos tido em tão pouco tempo. Por nosso amor a tudo superar dentro da eternidade do tempo que dura. É bom crescermos juntos e florescermos no sorriso feliz de quem sabe o que é felicidade. 
Sou grato aos meus tios, Nuccio e Yvonne, por me darem estrutura para alçar voos mais altos e sempre me apoiarem.

Sou grato à minha falecida tia Claudia, por sempre ter sido minha leitora e incentivadora número um. Sei que estás me lendo com carinho direto de Antares.

Sou grato a minha família Denecke e a minha família Rabello, por me mostrar maneiras distintas e complementares do amor e do convívio (respeito). Sou especialmente grato às minhas avós, Josepha Adozinda e Yvonne, e ao meu falecido avó, Hugo Rabello, que pouco conheci, mas do qual herdei, segundo algumas fontes, alguns trejeitos.

Sou grato aos meus amigos, dos quais tenho estado por demais afastado nestes 7 anos de intensa pesquisa. É hora de voltar a confraternizar. Em especial aos amigos de infância Robert Sattler, Igor Brücher, Leandro Chazarreta, Daniela Rodenbach; aos queridos amigos da época de faculdade e cujas trocas continuam até hoje Augusto Mello, Karina Pino, Paula Martini, Yuki Yokoi e Guga Millet. E todos os voluntários do CESOrj que durante a metade de meu mestrado compartilharam do trabalho voluntário em Friburgo. Aos amigos que se importaram e colaboraram direta ou indiretamente com a dissertação com suas indagações: Rachel Rech, Daniela Pereira, Larriza Thurler e Flavia Azevedo. À Michaela Krause, Sebastian Staschok e Marcel pela troca quanto às traduções, meu querido agradecimento.

Aos amigos e irmãos aos quais a vida gentilmente me reconectou e que me honram com sua amizade, carinho e troca diferenciada: João Pedro Demore, Marcelo Santos e Claudia Rossi.

Sou grato aos meus 6 cães - Tashi, Tara, Linda, Bope, Cleopatra e Fati - e 3 gatos - Petit Gateau, Vênus e Tao - por todo amor incondicional que me dão, ampliando a compreensão do que é amor e respeito e renovando as energias dia após dia. Saudosa lembrança de Athenas e Zinho, que me acompanharam na minha adolescência e me ajudaram a desenvolver amor e carinho na prática.

Sou grato aos meus alunos da ESPM que durante os últimos 5 anos e, em específico os últimos 3 anos de mestrado, tem generosamente dialogado com minhas teorias do Amor como gestor sustentável da informação e que resultou na pesquisa que aqui se configura dissertação. Sou grato a todos os meus alunos que tive ao longo desses 14 anos de ensino superior nos quais tive o privilégio de evoluir na troca sincera e construção colaborativa de conhecimento. Não consigo idealizar educação de outra maneira. Gratidão.

Sou grato aos meus alunos particulares de alemão e a seus pais que na reta final desta dissertação se mostraram muito flexíveis e generosos, acolhendo carinhosamente toda mudança de agenda que se fez necessário devido ao aperto dos prazos.

Sou grato a todos os meus mestres e professores. Agradeço aos professores da Escola Corcovado e em especial meus professores da Faculdade São Bento que me ensinaram a dar os primeiros passos em filosofia, bem como aos meus lamas que me ensinaram a dar os primeiros passos na minha mente-coração - em 
especial Dzongsar Khyentse Rinpoche, Jigme Rinpoche, Chagdud Tulku Rinpoche, Lama Pama Samten, Lama Jigme Lhawang e Lama Chimed; e a toda sangha. Especial agradecimento também aos meus professores de astrologia, José Maria Gomes Neto, Elizabeth Nakata e Dimitri Camiloto. Carinho especial à minha querida professora Frau Schroeders, que desde pequeno enxergou algo em mim e me indicou um cultivo diferenciado.

Sou grato a todos os funcionários da PUC-Rio que anonimamente fazem a instituição ser o que é e na qual tenho orgulho de trilhar quase a totalidade de minha jornada acadêmica.

Sou grato à Edna e à Diná por todo o carinho e a atenção com os quais sempre me atenderem e auxiliaram.

Sou grato aos meus amigos e colegas de mestrado por sua generosidade e troca edificante, com destaque para Alexandre, Alexandra, Daniella, Marius, Immanuel, Alyne, Carolina. Vocês tornaram as aulas e leituras algo de extremo interesse pela enriquecedora troca. Ao Daniel sou grato pela disponibilidade e troca quanto à sua dissertação sobre o amor de si.

Sou grato aos professores Dieter Schönecker e Friedo Ricken que foram de uma atenção e disponibilidade ímpares, tanto pessoalmente, quanto por e-mail. Ambos são desbravadores no campo de minha pesquisa e referência no assunto. Suas visões foram de extrema importância para o desenrolar de minha pesquisa.

Sou muito grato a Julia Pirschl, da Alber Verlag, que detém os direitos do artigo do professor Friedo Ricken: como o artigo não estava disponível para venda, a prestativa e atenciosa Julia digitalizou todo as páginas e o enviou em menos de 30 minutos. Pequenos gestos assim foram fundamentais para seguir adiante.

Sou grato aos meus professores do mestrado, em especial ao Professor Edgard José Filho, que com seu entusiasmo jovial na leitura da Crítica da razão pura e na pesquisa sobre o intellectus archetypon me fascinaram e fizeram reconhecer a verdadeira grandeza do mestre de Königsberg, fazendo de Kant minha referência número um. É tanto uma honra, quanto um prazer ter o Prof. Edgard em minha banca.

Sou grato ao Professor Fernando Rodrigues, a quem não conheço ainda pessoalmente enquanto escrevo estas linhas, simplesmente por ter aceito participar de minha banca. E na certeza de que ninguém cruza nosso caminho sem um propósito - a vida apenas nos convida a revelar seu mistério.

Por fim, mas por demais fundamentais e, diria mais, por princípio, meu sincero agradecimento à minha orientadora, professora Vera Cristina de Andrade Bueno. Quando procurei o mestrado de filosofia na PUC-Rio, munido de um artigo debaixo do braço e um sem fim de ideias na cabeça, tendia mais para estudos de Nietzsche e Spinoza. Nossa entrevista inicial, que tivemos na mesma sala de nossa última conversa, me fez ver a importância de estudar Kant não somente para minha pesquisa e interesse pessoal, como também para meu próprio ser. Algo me dizia para confiar cegamente em sua condução. E o fiz dentro de minhas limitações. E quantos obstáculos, atrasos e alterações. Obrigado por sua paciência, 
carinho e generosidade. Se esta dissertação está de pé, devo ao seu apoio. Espero lhe honrar com minha dedicação e resultado: é um grande desafio e uma responsabilidade e tanto ser seu último mestrando. Ter aceito me orientar mesmo tendo se aposentado demonstra o tamanho de sua generosidade - e espero que também a fé que depositastes em mim lá no início, mesmo com um texto por demais autoral e fora dos padrões acadêmicos vigentes. Dei meu máximo para consertar isto e sei que ainda tenho que melhorar muito.

Sou grato por poder agradecer. Se algo sou, é pelos outros, não posso me esquecer. 


\section{Resumo}

Rabello, Klaus Denecke; Bueno, Vera Cristina de Andrade. "Selbstliebe na obra de Kant - Para além da disposição original para o bem ou fonte de todo mau, progresso moral”. Rio de Janeiro, 2014. 96p. Dissertação de Mestrado - Departamento de Filosofia, Pontifícia Universidade Católica do Rio de Janeiro.

Baseado nas leituras dos textos de Kant referentes ao conceito de Selbstliebe, traduzido para o português por de amor de si, amor a si e amor próprio, a dissertação procura dar conta dos diferentes sentidos nos quais o termo é empregado, bem como elucidar a relação possível de ser estabelecida entre esses sentidos e o conceito de autoestima, de amor e de moralidade no progresso moral do ser humano. Comumente entendido como um obstáculo à moralidade, buscaremos comprovar a hipótese de que a Selbstliebe é antes um fator vital para o progresso moral da humanidade.

\section{Palavras Chaves}

amor; Selbstliebe; humanidade; coração; ação moral. 


\section{Abstract}

Rabello, Klaus Denecke; Bueno, Vera Cristina de Andrade. "Selbstliebe in Kant's work - beyond the original disposition to the good or source of all evil, moral progress". Rio de Janeiro, 2014. 96p. MSc. Dissertation Departamento de Filosofia, Pontifícia Universidade Católica do Rio de Janeiro.

Based on the readings of Kant's texts regarding the concept of Selbstliebe, translated into Portuguese as love for oneself, and self-love, the dissertation seeks to analyze the different senses in which the term is used, as well as elucidate the possible relationship to be established between these senses and the concepts of self-esteem, of love and morality in the moral progress of the human being. Commonly understood as an obstacle to morality, we seek to prove the hypothesis that Selbstliebe is vital to the moral progress of humanity.

\section{Keywords}

Love; Selbstliebe; humanity; heart; moral action 


\section{Sumário}

1. Introdução 13

2. Numero Idem - uma chave de leitura para entender o amor de si como progresso moral na relação entre dever e liberdade

3. Selbstliebe para além da disposição original para o bem ou fonte de todo mau

3.10 que é Selbstliebe?

3.2 Fonte de todo mau

3.3 Disposição original para o bem

4. O Amor de si racional enquanto amor à lei: progresso moral de si ao conceito de humanidade

5. Conclusão

88

6. Referências bibliográficas 


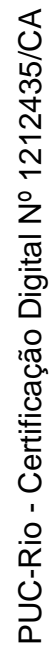

Amai para entendê-las!

Pois só quem ama pode ter ouvido.

Capaz de ouvir e entender estrelas.

Olavo Bilac 


\section{Introdução}

Talvez devamos iniciar nossa dissertação retirando do título ${ }^{1}$ toda sombra de presunção: o título é bilíngue apenas para atender aos principais casos em que o conceito de Selbstliebe, tratado por Kant em sua filosofia prática, foi traduzido, já que encontramos diferentes sentidos para o conceito ora como amor próprio, ora como amor de si e ainda, em um caso específico, como amor a si; a estas distinções dedicaremos algumas considerações ao longo e ao final desta dissertação. A título de clareza, utilizaremos exclusivamente o termo amor de si mesmo racional para a Selbstliebe, quando se trata do seu caráter racional e amor de si mesmo quando se trata de caráter misto; e amor a si quando se trata apenas de nossa animalidade, reservando amor-próprio para os casos em que Kant faz uso do termo Eigenliebe. Quanto a esta distinção, faremos uma breve análise etimológica e comparativa dos termos Eigen (próprio) e Selbst (a si). É bom lembrar ao leitor que essas especificações não atrapalham em nada a proposta kantiana em relação a esse tema, todavia podem gerar, na tradução para o português, alguns equívocos de interpretação ou perda de nuances.

Antes de prosseguirmos consideremos, contudo, a escolha deste tema no contexto da obra de Kant. Dentro de todo o sistema crítico kantiano mais do que a representação do dever, que ocorre pelo respeito à lei, diferentemente da maioria dos comentadores e talvez da própria proposta de Kant o que mais despertou o meu interesse foi pesquisar o que leva o ser humano a seguir a lei, a cumprir o dever. Dispus-me a analisar o que leva o ser humano a, efetivamente, praticar a ação moral, a estabelecer o progresso moral em suas relações. A maioria dos comentadores, em função da proposta kantiana para a moralidade, avalia que uma ação é moral quando é determinada exclusivamente por dever, pela subordinação das máximas individuais à lei dada pela razão.

\footnotetext{
${ }^{1}$ Há também outra questão a ser esclarecida quanto ao título: o uso de bem/mal, bom $/ \mathrm{mau}$. Seguindo indicação do próprio Kant em sua Crítica da razão prática, bom/mau é utilizado para se referir à moralidade e bem/mal para se referir a algo físico, como bem estar. Bem é para o Sumo bem, a ser atingido numa vida futura, onde se realizaria a esperança de ser feliz. Eis o motivo pelo qual o subtítulo contém bem e mau, uma vez que a) o amor de si racional dispõe justamente para o (sumo) bem, já que o bom (o bem moral) é fruto da razão; b) o amor-próprio é fonte de todo mau (o mal moral, a escolha equivocada da hierarquia das máximas, não subordinando-as à lei), o que leva à manifestação do mal radical, a inata propensão para o mau, que passa da ordem da liberdade/moralidade (mau) para a esfera da natureza (mal).
} 
Kant estabelece a ação moral a partir do respeito à lei, o que solta a humanidade das amarras do mundo sensível por não fundamentar a moralidade em função da relação dos seres humanos entre si, colocando-os diante do suprassensível no qual a liberdade é possível. Através da virtude de obedecer a lei e assim superar nossas inclinações, tornarmo-nos dignos da felicidade. Resumidamente e a título de fundamentação para a dissertação que se segue, podemos estabelecer que toda ação moral se baseia na lei oriunda da razão que, por exercer uma coerção sobre o ser humano, funciona como um imperativo e, por ser um imperativo sem nenhuma condição a não ser o fato de ter origem na razão pura, é categórico. Podemos reconstruir em quatro etapas tal afirmação: 1) a boa vontade - para Kant, razão prática e vontade são a mesma coisa e a boa vontade não é outra senão a vontade que quer seguir a lei. Ou, nas palavras de Kant, a boa vontade é aquela cuja "máxima é sempre conforme à lei", sendo "condição suprema de todo bem" ${ }^{2}$. Portanto, só existe um critério para o qual uma ação é moral e eis a boa vontade, determinada pelo dever; 2) o dever uma vontade só é boa quando é determinada pelo dever, bem como uma ação só é boa quando determinada pelo dever, sem considerar em si objetivos, intenções e motivações pontuais. O valor da ação moral reside unicamente na obediência ao dever, sendo o maior dever seguir a máxima que se determina pela lei da razão pura; 3) a máxima - uma máxima é um princípio que vale para o sujeito que a formulou - é uma representação subjetiva de princípio de ação, sendo a aplicação prática e singular de um princípio. Para ser moral, a máxima tem de poder ser universalizável; 4) o imperativo categórico - ordena que a lei seja seguida, apesar dos obstáculos oriundos da sensibilidade (impulsos e prazeres). Assim, agir por dever é seguir a lei, o imperativo máximo a ser respeitado, independentemente dos objetivos e impulsos momentâneos que possam nos desviar daquilo que temos de fazer a partir dos fins que nos colocamos a partir dos princípios da razão. Agir por dever leva o ser humano a fazer o que é determinado pela razão, independente dos impulsos e necessidades de uma situação concreta. Em função dessa determinação da razão e do ter de abrir mão do que afeta o ser humano em função de suas inclinações é preciso lançar mão do conceito em função do qual a determinação da razão pura pode ser seguida: a ideia de liberdade. Apenas se o ser humano se pressupuser livre ele pode se dispor a cumprir a lei. Por ser praticamente racional, o ser humano tem uma vontade autônoma: ou seja, ele dá a lei a si

${ }^{2}$ KpV AA 109 
mesmo. Ela não lhe é dada por outro ser humano. No sistema kantiano, é possível levar em conta o conceito de moralidade porque Kant formulou o conceito de liberdade de modo a que ele não entre em contradição com a causalidade existente no mundo dos fenômenos, a saber, no mundo sensível. Não há em Kant, portanto, conflito entre liberdade e obrigação, sendo esses dois conceitos faces complementares de uma mesma determinação. Ser moral é determinar-se por princípios que valem universal e objetivamente como lei para todos, incluindo o indivíduo, e agir em respeito a esta lei é atuar coerentemente na escolha subjetiva de cada ação. Essa proposta faz parte do sistema de uma razão pura prática, de uma razão pura que determina diretamente a vontade. É diante do edifício do pensamento crítico kantiano, no qual todo exercício do dever ocorre acompanhado pelos sentimentos de respeito e amor ${ }^{3}$, que o tema do amor de si ganhou importância nesta pesquisa: o tema do respeito à lei, estabelecido pela representação da lei, já foi amplamente debatido pela comunidade kantiana, mas o lugar do amor, em específico do amor de si, merece ganhar mais destaque quando se trata do cumprimento do dever ${ }^{4}$.

Uma vez considerados os conceitos de liberdade e de moralidade, procurarei argumentar em que sentido o amor ajuda na realização do dever e, quando tem sua parcela de presunção do amor de si aniquilada, dá vazão ao sentimento moral, como veremos adiante. Sabendo que, ao menos aparentemente, o amor de si é um impedimento à moralidade para Kant, como, e sob que circunstâncias, o amor de si mesmo é auxílio e não impedimento à ação moral? Podemos afirmar que o amor de si mesmo pode ser entendido como dever? De certo, não o amor de si sensível, mas o amor de si racional, como veremos a seguir; e que, de certo, não se pode obrigar a amar no sentido estético ${ }^{5}$ - do sentimento que emerge do encontro das sensações -, mas a racionalmente aspirar ${ }^{6}$ a cumprir com satisfação os deveres, a começar por amar a si - no sentido de cuidar de sua animalidade - para dar embasamento ao cumprimento dos deveres para com os outros. Mais do que o respeito à lei, que é o princípio de tudo e sem o qual o amor verdadeiro também não existe ${ }^{7}$, amar é cumprir com o respeito sendo exemplo prático da lei; é afirmar a lei em sua

\footnotetext{
${ }^{3}$ TL 448

${ }^{4}$ A falta de dimensionamento da ética de Kant como sistema dos fins, onde o amor ganha maior relevo, pode ser lido no comentário de Rudolf Langthaler na introdução de seu "Kants Ethik als 'System der Zwecke'", ainda inédito em português

5 TL 449

${ }^{6} \mathrm{KpV} 148$

${ }^{7} \mathrm{O}$ fim de todas as coisas - p.13
} 
ação, é querer o respeito na prática, é agir por dever e com satisfação. A satisfação de quem está consciente de estar agindo moralmente, o que é possível sob a condição da subordinação de suas máximas à lei moral ${ }^{8}$, o que Kant chama de Selbstzufriedenheit ${ }^{9}$, o contentamento de si mesmo que emerge da consciência da virtude e é análogo da felicidade, servindo de lastro para a autoestima moral e assim, como veremos, para o cumprimento do dever. A dissertação procura argumentar que o amor de si é, então, a base para a realização do dever e de seus fundamentos. Isto, mesmo sabendo que Kant deixa claro que a representação do dever necessita da pureza da lei, não somente não recebendo auxílio, a não ser o impulso do sentimento moral oriundo do respeito, mas tendo no amor de si um obstáculo à moralidade. Para representar a lei não pode haver influência do amor de si, para cumprir a lei o amor de si é necessário.

Quem bem explica a Selbstliebe e sua relação com a presunção, a arrogância, a autoestima e moral e assim a relação humana com o bem e com o mau, é Prof. Friedo Ricken, em seu artigo, ainda sem tradução para o português, Kant über Selbstliebe: Anlage zum Guten oder Quelle alles Bösen? ${ }^{10} \mathrm{O}$ artigo foi integrado na pesquisa deste trabalho nos últimos dias de produção do texto, mas serviu como importante interlocutor desta dissertação, tendo se juntado a Dieter Schönecker, que aborda a compreensão e teoria do amor em Kant em seu artigo "O amor ao ser humano como disposição moral do ânimo no pensamento de Kant" e "Kant, sobre a possibilidade de deveres para consigo mesmo (Tugendlehre 1-3)", e a Daniel Leite Cabrera Pereira Rosa com sua dissertação "O amor de si em Kant" no conjunto dos comentadores mais utilizados para a realização desta pesquisa.

A hipótese deste trabalho é investigar em que medida a Selbstliebe, traduzida por amor-próprio, amor de si mesmo ou ainda por amor a si, pode ser considerada como a melhor medida para o progresso moral. É necessário estabelecer limites claros para esta hipótese do progresso moral ser o cultivo do amor em si mesmo com vistas a cumprir a lei com satisfação. O próprio Kant considera o amor de si mesmo (Selbstliebe) um impedimento para a vida virtuosa e a prática da moralidade. Todavia, deixa em aberto na Crítica da razão prática a possibilidade de se contar com o amor de si racional (vernünftige

\footnotetext{
${ }^{8}$ Religion B50

${ }^{9} \mathrm{KpV} 212$

${ }^{10}$ Kant sobre o amor de si: disposição para o bem ou fonte de todo mau?
} 
Selbstliebe) na empreitada de agir segundo a determinação da lei da razão pura, que é a lei do dever que nós mesmos nos colocamos. E não basta nos colocarmos a lei e agir conforme o dever. É necessário que tenhamos também uma disposição interior para isso: é preciso querer agir de acordo com a lei, ter, como já mencionado anteriormente, a boa vontade, esse querer que é, segundo a interpretação aqui proposta, o amor de si mesmo racional enquanto amor à lei. Com o amor de si racional dentro dos justos limites da lei, já não há mais impedimento da inclinação à lei, tendo a virtude conduzido o amor de si ao amor de si racional que, como amor prático, cumpre a lei com satisfação. Ou seja, o amor de si racional, muito mais que apenas uma disposição para o bem ou fonte de todo mau, é a melhor medida para o progresso moral, pois o amor à lei traz consigo a questão da universalidade que abrange assim toda humanidade, da qual o indivíduo faz parte. E "só é possível alguém amar-se a si mesmo de modo moral enquanto é consciente da sua máxima de fazer do respeito pela lei o supremo motivo impulsor do seu arbítrio"11.

A hipótese se baseia na duplicidade da natureza humana, concomitantemente noumênica e fenomênica, e justifica da seguinte maneira: 0 amor de si mesmo é fonte de todo mau quando é utilizado para determinar a escolha das máximas, impedindo que se cumpra a lei dada pela razão. Ao sofrer dano por parte da razão pura prática, o amor de si mesmo passa a ser justo e conforme os limites da lei e deixa de ser fonte de todo mau, subordinando-se à lei. Enquanto disposição originária para o bem, o amor de si mesmo dispõe da base para a comunicabilidade da razão ao estabelecer o impulso à sociedade e a comparação racional à igualdade. A partir do momento em que se subordina à lei e garante assim sua disposição originária para o bem, o amor de si, agora amor de si racional, serve de parâmetro edificador do amor recíproco, e configura a passagem à autoestima que alicerça relações morais entre indivíduos iguais perante a lei moral, progredindo assim a uma humanidade baseada em relações de amizade.

Pretendo proceder da seguinte maneira na dissertação: no primeiro capítulo, ofereço uma chave de leitura para viabilizar o entendimento da proposta, a possibilidade da passagem do amor de si ao amor de si racional indicando a viabilidade do progresso moral através do diálogo entre nossas manifestações fenomênicas e nossa natureza noumênica, a forja de nossa

\footnotetext{
${ }^{11}$ Religion B52 nota de rodapé
} 
personalidade oriunda da natureza e da liberdade, uma vez que enquanto indivíduo que somos, forjamos a unidade de nossa personalidade a partir do diálogo entre nossas parcelas fenomênica e moral; no segundo capítulo ressalto a necessária pureza da lei na escolha das máximas morais, ou seja, a inviabilidade de contar com o amor-próprio como máxima moral e como daí surge o fato do amor de si mesmo se tornar fonte de todo mau. Prossigo ainda no segundo capítulo, apresentando a noção do amor a si e o amor de si mesmo como disposições originárias para o bem, como podemos ler na Religion. Ao deixar claro em que medida estes termos não são conflitantes, mas, antes promovem o progresso moral, procuro mostrar, no terceiro capítulo, em que medida a hipótese se justifica fazendo uso da complementaridade dos termos aparentemente opostos apresentados no segundo capítulo. Concluo esta dissertação realizando um resumo e apontando possíveis implicações, sobretudo na tradução do termo Selbstliebe para o português.

A citação da obra de Kant se dará da seguinte maneira: $K p V$ indica a Crítica da razão prática; Religion indica a Religião nos limites da simples razão; $K U$ indica a Crítica da faculdade do juízo; Ethica indica o inédito em português Eine Vorlesung über Ethik, uma reunião de transcrições das aulas ministradas por Kant entre 1775 e 1785; TL indica a Doutrina das virtudes; O fim de todas as coisas não recebeu abreviação na indicação de referência, bem como se manteve por inteiro a referência ao Conflito das faculdades; Was ist Aufklärung? indica $O$ que é esclarecimento? e Vorkritische Schriften se refere aos Escritos pré-críticos; ambos os títulos foram utilizados no original e na versão traduzida e a referência revela a origem da citação. Toda literatura foi lida no original, sendo as traduções utilizadas para facilitar as citações e a comparação com o entendimento local vigente. 


\title{
Numero Idem ${ }^{12}$ - uma chave de leitura para entender o amor de si como progresso moral na relação entre dever e liberdade
}

Se a humanidade fosse apenas animal, estaria presa às suas inclinações e não haveria horizonte possível para sua moralidade. Se a humanidade fosse apenas puramente racional, estaríamos diante da santidade da vontade e nossas máximas seriam leis, sendo a boa vontade santa por não haver sequer mácula de obstáculo oriundo das inclinações. Ocorre que Kant compreende a humanidade como uma passagem da imperfeição à perfeição moral ${ }^{13}$, um devir moral $^{14}$ do indivíduo que, através da sociedade, torna possível a perfeição na espécie, sendo exemplos respectivos o texto da Religião nos limites da simples razão e aquele do Rumo à paz perpétua. Esta passagem do ser humano em constante progresso na afirmação de sua vontade - razão prática - requer soberania sobre si mesmo (através da razão) e deve evitar ao máximo o conflito entre sua natureza fenomênica e sua moral, pois só há conflito por falta de compreensão.

\begin{abstract}
Somente quando o humano se governar tão bem que impeça toda e qualquer indignação da turba em sua alma e assim alcançar sua paz (a paz da alma não é a satisfação com tudo, mas a boa governança e unidade da $\mathrm{alma}^{15}$ ), se conseguir conduzir um bom governo como tal em si mesmo, então não surgirá nenhuma guerra nele, e onde não há guerra ${ }^{16}$, não há a necessidade de vitória. Por isso, é muito melhor se governar de tal forma que não se precise obter uma vitória sobre si mesmo. ${ }^{17}$
\end{abstract}

Não há, no sentido último, conflito e antagonismo irreconciliável entre nossas manifestações fenomênicas e nossa natureza noumênica. Há no máximo impaciência e incompreensão resultantes do imediatismo demandado pelas inclinações, as turbas cegas que se esclarecem ao se curvar à razão.

\footnotetext{
${ }^{12}$ Numero idem é o termo em latim que Kant utiliza para esclarecer que - apesar da dupla disposição da personalidade retratada como noumenon-phaenomenon, juiz-réu e professor-aluno - trata-se sempre da mesma pessoa.

${ }^{13}$ Religion B73

${ }_{15}^{14}$ Zum ewigen Frieden - conclusão

${ }^{15}$ Pode-se traçar aqui uma analogia com a estrutura e proposta do escrito Rumo à Paz Perpétua

${ }^{16}$ Vom Kriege

17 Ethica - Teil B - p.160
} 
Os sentidos [...] são como o povo comum, que, se não agem como turba (ignobile vulgus), gostam de se submeter a seu superior, o entendimento, mas querem ser ouvidos. ${ }^{18}$

A atenção criada pelo respeito à lei, gera as condições necessárias para que o indivíduo compreenda suas inclinações, seu dever e se orquestre de acordo com sua liberdade, baseado na comunicabilidade da razão que tece o diálogo entre suas partes, curvando-as à lógica da razão pura prática. Uma vez que o dever compreende a liberdade de escolha, a escolha da máxima moral - 0 fundamento subjetivo - em respeito à lei - o fundamento objetivo - é justamente fazer o que deve ser feito. É seguir a lei da razão que o ser humano mesmo visa: temos a liberdade - inerente ao conceito de dever - de sermos coerentes e consistentes com nossos próprios princípios e temos a habilidade de usar os meios para realizar os fins que nós mesmos nos colocamos. É, portanto, por amor à lei na figura do amor prático ${ }^{19}$, que me ordeno a aspirar ao cumprimento de meus deveres para com o próximo com satisfação, que ocorre a livre adoção da $l \mathrm{ei}^{20}$ que, por ser fruto da razão pura, legisla incondicionada e imperativa, equanimemente. A relação de igualdade por excelência se encontra na amizade, como lemos na página 220 da Ethica, que nos oferece mais ingredientes para pensarmos este amor à lei e a execução com satisfação de nossos deveres para com o Outro e sua relação com o amor de si mesmo, já que "o maior amor para com o Outro é quando o amo como a mim mesmo"21. Como isto seria possível se Selbstliebe fosse somente compreendida, como ocorre na Crítica da razão prática, como parte integrante do egoísmo ${ }^{22}$ ? O egoísmo, união do amor próprio e da complacência consigo mesmo (presunção), é justamente àquilo a que a lei moral, através da razão pura prática, causa dano. A lei moral aniquila assim a presunção e impõe limites ao amor próprio. O amor próprio passa então a ser chamado de amor de si racional e tem "limites justos e correspondentes à Lei Moral, estando, ainda antes de manifestar-se, natural e vivo em nós”. ${ }^{23}$ É como se o amor próprio fosse uma passagem, uma ponte que unisse a dupla natureza

\footnotetext{
${ }^{18}$ Anthropologie 145

$19 \mathrm{KpV} 148$

${ }^{20} \mathrm{KpV} 144$ - „bloss um des Gesetzes willen geschehe“ foi traduzido por Rodolfo Schaefer por „somente por amor pela lei“; a tradução de Afonso Bertagnoli não menciona a palavra amor. Defenderemos o uso da palavra amor neste contexto quando da abordagem no subcapítulo da Crítica da razão prática, bem como ao final deste trabalho, mas a pista parece se encontrar na já citada passagem de O Fim de todas as coisas, de que o amor é a livre adoção da vontade alheia sob sua máxima, interpretada à luz do conceito de Numero Idem, cuja personalidade noumênica apresenta a lei e cuja personalidade fenomênica a cumpre como dever.

${ }^{21}$ Ethica - Teil B - p. 218

${ }^{22} \mathrm{KpV} 129$

${ }^{23} \mathrm{KpV} 129$
} 
humana: natureza fenomênica e a noumênica, a natureza moral. Kant expõe na Doutrina da virtude essa dupla natureza humana:

Para que a razão não caia em contradição consigo mesma, é preciso uma explicação sobre a dupla personalidade, com a qual o homem, que se acusa e se julga na consciência moral, tem de pensar a si mesmo; sobre este duplo eu mesmo [Selbst] ... sou um e o mesmo homem (numero idem ${ }^{24}$ ), mas enquanto sujeito da legislação moral, proveniente do conceito de liberdade, em que o homem está submetido a uma lei que ele dá a si mesmo (homo noumenon), deve ser considerado como diferente do homem sensível dotado de razão (specie diversus), mas apenas do ponto de vista prático $[\ldots]^{25}$

O amor de si racional é, portanto, algo humano, demasiado humano partilhando de nossa parcela fenomênica, homo phaenomenon, por estar "ainda antes de manifestar-se, natural e vivo em nós", e por ser cultivado por nossa livre ação conforme a lei, tendo assim mais proximidade com nossa parcela noumênica, homo noumenon. Encontramos aqui uma chave de leitura para entendermos o aparente paradoxo que se apresentava quanto ao termo Selbstliebe. Se há dois Selbst, então há de haver ao menos a possibilidade de dois amores, cada qual tendo como objeto um dos Selbst, mencionados:

1) um eu fenomênico, foco do amor de si, que se alterna na medida do tempo da manifestação fenomênica do conjunto das inclinações, o que Kant chama, na Crítica da razão prática, de egoísmo (solipsismus), um esforço do eu (Selbst) patologicamente determinável e que cria o vício na felicidade pessoal através da: a) "benevolência (Wohlwollen) acima de tudo para consigo mesmo (philautia)"26,

tendo a tendência de fazer de si mesmo o princípio objetivo da determinação da vontade em geral, segundo os fundamentos subjetivos da determinação do seu livre-arbítrio, pode denominar-se amor de si, o qual, se se tornar legislador e princípio prático incondicionado, pode chamar-se presunção (Eigendünkel). ${ }^{27}$

e b) complacência (Wohlgefallen) de si próprio (arrogantia). Denominamos a) particularmente amor-próprio (Eigenliebe) e b) presunção (Eigendünkel).

\footnotetext{
${ }^{24}$ Numero idem é o termo em latim que Kant utiliza para esclarecer que - apesar da dupla disposição da personalidade retratada como noumenon-phaenomenon, juiz-réu e professor-aluno - trata-se sempre da mesma pessoa.

${ }^{25} T L$ nota de rodapé a 439

${ }^{26} \mathrm{KpV} 129$

${ }^{27} \mathrm{KpV} 131$
} 
Além deste eu fenomênico há um outro, 2) um eu noumênico, chamado de eu autêntico, ao qual se destina o amor de si racional, e identificado com sua vontade $^{28}$. Como Kant descreve na Doutrina da virtude ${ }^{29}$, é a liberdade interna do homo noumenon que garante a possibilidade da razão do homo phaenomenon, a partir dos deveres para com a humanidade em si, ser a causa da ação no mundo dos sentidos. Deveres oriundos, por sua vez, da personalidade - a ideia da humanidade considerada de modo plenamente intelectual ${ }^{30}$-, sem haver qualquer contradição entre sermos seres livres e ao mesmo tempo termos obrigações.

O que eu sou, enquanto ser sensível-racional, é aquilo que eu, enquanto ser racional e assim como meu eu autêntico, quero por mim mesmo. ${ }^{31}$

Vale ressaltar o pensamento que acompanha os demais trechos supracitados da Crítica da razão prática, nos quais se trata do amor de si, segundo os quais "a tendência à estima a si mesmo está entre as inclinações a que a lei moral causa dano, enquanto essa autoestima baseia-se unicamente na sensibilidade" ${ }^{\prime 2}$. Esta citação é um reforço da relação do amor de si e da autoestima, sendo praticamente equiparadas por Kant: enquanto o amor de si recebe da razão dano causado ao amor próprio [Eigenliebe] e tem sua presunção aniquilada, a estima de si mesmo sofre dano enquanto se baseia unicamente na sensibilidade. Em ambos os casos, temos a possibilidade de versões racionais, a saber: o amor de si racional e a autoestima moral, pautadas pelo respeito à lei. Tanto no amor de si, quanto na autoestima, a questão frente à moralidade recai sobre seu fundamento ser unicamente sensível. Isto reforça a importância do amor de si e da autoestima poderem servir de ponte entre as personalidades humanas por partilharem de ambas as naturezas, sendo uma passagem entre a animalidade fenomênica e a personalidade racional, pois "a humilhação pelo lado sensível é uma elevação da estima moral"33. Quanto maior a racionalidade do amor de si, maior a possibilidade da autoestima moral. Afinal, como se lê ainda na Crítica da razão prática, é graças ao amor de si que podemos compreender como é possível discernir a lei moral a priori e seu efeito negativo sobre o sentimento justamente por causar dano ao amor de si,

\footnotetext{
${ }^{28}$ GMS 458

${ }^{29} \mathrm{TL}: 418$

${ }^{30}$ Religion B19

${ }^{31}$ GMS Einleitung XXXVI (Bernd Kraft und Dieter Schönecker)

${ }^{32} \mathrm{KpV} 129$

${ }^{33} \mathrm{KpV} 140$
} 
excluindo as inclinações e a tendência a fazer delas a condição prática suprema. O efeito positivo da razão pura prática - ao não admitir nenhuma espécie particular de sentimento que anteceda ou sirva de base à lei moral - não se choca com o sentimento moral que é fundamental para a adoção da ação moral, antes apenas delimita hierarquias e funções. No contexto da criação do sentimento de respeito para com a lei moral, o amor de si, "natural e vivo em nós"34, auxilia a vontade em seu discernimento para que esta afaste, do caminho da razão, a resistência das inclinações. "Toda diminuição de obstáculos de uma atividade age como fomento dessa mesma atividade"35, ou seja, o amor de si fomenta a razão prática na medida em que ele sofre o dano que viabiliza o sentimento moral, servindo de anteparo para a razão projetar sua lei e assim, por um lado, exercer o respeito para com a lei moral e, por outro, dar limites justos ao amor de si, que passa a ser o amor de si racional justamente pela atuação do respeito à lei. É na prudência, máxima do amor-próprio, que temos a segurança necessária para contemplar a sublime destinação de nossa natureza suprassensível e começamos a ter motivos para nos estimar enquanto sujeitos morais. Passamos, através do respeito à lei, a um amor maior, um amor próprio ao eu autêntico, o do homo noumenon, esta personalidade que representa a ideia de humanidade em nós e honra, através de suas escolhas, o seu valor, lastreado por sua liberdade de se colocar fins. E o valor que devemos honrar enquanto sujeitos morais é a liberdade que em nós reside, fundada assim em nosso caráter inteligível. Reforçamos assim a hipótese deste trabalho: de que a Selbstliebe, mais do que somente um obstáculo à moralidade, é antes, enquanto amor de si racional [vernünftige Selbstliebe], um fator vital para o progresso moral da humanidade. Enquanto amor ao si-mesmo [Selbst] invisível ${ }^{36}$, a personalidade acessível somente ao entendimento e com o qual reconhecemonos em conexão universal e necessária, valorizamos nosso intelecto, no qual a lei moral revela nossa vida independente da animalidade e de todo mundo sensorial. É a partir do marco da humildade que emerge do contato com o sublime, do conhecimento de si que ocorre a partir da comunicabilidade do belo e de nossas máximas imutáveis oriundas de nosso juízo que forjamos nosso caráter. E por mais que a moralidade necessite da pureza da lei em seu princípio, precisa do amor para que seja efetivada dentre os seres humanos.

\footnotetext{
${ }^{34} \mathrm{KpV} 129$

${ }^{35} \mathrm{KpV} 140$

${ }^{36}$ KpV AA 189
} 
Com sua colocação sistemática, Kant se distancia da polarização Coraçãocontra-Razão, já que, diferente da popular afirmação de Blaise Pascal - "o coração tem seus motivos, que a razão desconhece" - Kant empreende justamente compreender os motivos e os fundamentos do coração e precisamente dentro dos limites da simples razão. ${ }^{37}$

${ }^{37}$ Religion B21 - Comentário do Editor - livre tradução desta dissertação. Original para fins de clareza e comparação: Mit seiner systematischen Platzierung setzt sich Kant deutlich von der Polarisierung Herz-gegen-Vernunft ab, denn im Unterschied zu der populären Auffassung Blaise Pascals - „Das Herz hat seine Gründe, die die Vernunft nicht kennt“ - unternimmt Kant es ja gerade, genau die Gründe des Herzens zu erkennen und zwar innerhalb der Grenzen der blossen Vernunft" 


\section{3 \\ Selbstliebe - para além da disposição original para o bem ou fonte de todo mau}

Para garantir a independência da animalidade e de todo mundo sensorial, honrando nossa personalidade, precisamos inicialmente estabelecer a necessária pureza da lei na escolha das máximas morais, ou seja, a inviabilidade de contar com o amor-próprio como máxima moral. A vontade deve ser pura, pois como razão prática pura, deve ser determinada pelo respeito à lei, a lei por si só, e não sofrer influência de móbil sensorial algum. Em inúmeras passagens ao longo de toda sua obra, como nesta da Crítica da razão prática, Kant indica claramente que

O valor moral das ações depende em sua essência do fato de que a lei moral determine imediatamente a vontade. ${ }^{38}$

Da lei moral como determinante da vontade

Ou seja, a vontade deve ser determinada direta e exclusivamente pela lei, não sofrendo influência de sentimento patológico algum ou ainda qualquer espécie de incentivo, inclusive racional a serviço de algum interesse das inclinações. Se assim o fosse, a vontade estaria no máximo conforme a lei, tendo legalidade, mas não moralidade. O motor (elater animi) da vontade humana não pode ser outro senão a lei moral. A lei, enquanto fundamento objetivo, deve bastar também como fundamento subjetivo, ou seja, a máxima subjetiva deve ser universalizável, passível de se objetivar.

[...] o fundamento objetivo de determinação tem que ser sempre e por si apenas, ao mesmo tempo, o fundamento subjetivo suficiente de determinação da ação, porque esta responde perante o espírito da lei, não encerrando somente a sua letra. ${ }^{39}$

Ainda na Crítica da razão prática, Kant deixa bem claro e evidente que não há outra maneira de agir moralmente senão por dever, tendo por princípio a lei moral, opondo-se ao amor-próprio.

\footnotetext{
${ }^{38} \mathrm{KpV} 126$

${ }^{39} \mathrm{KpV} 126$
} 
Os limites da moralidade e do amor-próprio estão assinalados com tal clareza e precisão que até a visão mais vulgar não pode deixar de distinguir se uma coisa pertence a um ou a outro. ${ }^{40}$

Kant adverte inclusive aos perigos de se utilizar outros móbiles

Para a finalidade da lei moral e para proporcionar-lhe um influxo sobre a vontade, não há necessidade de buscar qualquer motor estranho que substituísse o da lei moral, pois isso tudo resultaria em pura e inconsistente hipocrisia, sendo até perigoso (bedenklich) deixar que alguns outros motores (como o do proveito) cooperem com a lei moral, ainda que seja apenas paralelo a ela $[\ldots]^{41}$

\section{Da lei moral como valor interior}

Ressaltemos desta citação o termo paralelo, que evidencia a incompatibilidade da concomitância dos motores sensíveis do amor de si com a lei moral, que na Religion é indicado como impureza do coração ${ }^{42}$, uma das três fontes do mau. Veremos esta e as demais com mais precisão adiante. Todavia, isto não impede a subordinação dos diferentes móbiles ante a lei moral, que deve ser soberana como princípio e assim limita os demais móbiles à obediência da lei. Assim a lei moral converge as diferentes forças dos interesses empíricos à realização da ação moral a partir da virtude, força moral interior que consiste na intenção (Gesinnung) ${ }^{43}$ moral e é autodomínio e superação ${ }^{44}$. A lei moral representa assim nosso verdadeiro valor interior ${ }^{45}$ ao subjugar e canalizar as inclinações, elevando nossa existência ao sublime, a infinita grandeza da existência racional humana acima de nossa natureza sensível. $O$ entendimento da citação retrocitada é fundamental para estabelecer a importância da pureza do móbil moral, ressaltando tratar-se da determinação da vontade em função da lei moral. Como vontade livre, ela é compreendida sem a cooperação dos impulsos sensíveis causando dano a todas as inclinações, quando contrárias à lei, sendo exclusivamente determinada pela lei ${ }^{46}$.

\footnotetext{
${ }^{40} \mathrm{KpV} 63$

${ }^{41} \mathrm{KpV} 127$

42 Religion B21

${ }^{43}$ Ethica - Teil B - p.84

${ }^{44}$ Ethica - Teil B - p.85

${ }^{45}$ Ethica - Teil B - p.149

${ }^{46} \mathrm{KpV} 128$
} 
Da lei moral como motor

A certeza da razão pura prática, ou seja, da vontade de coincidir com a lei é o princípio de valor de toda pessoa ${ }^{47}$, que necessita da convergência da intenção para que possa não apenas ser princípio objetivo universal, mas também tornar-se fundamento subjetivo de respeito. Isso é possível ao humilharmos a consciência de nosso valor pessoa, excitando em nós o respeito próprio por conseguirmos resistir e superar a tendência sensível da natureza. Por ser motivo positivo e determinante do respeito próprio dos princípios a lei é em si o motor moral enquanto respeito à lei em si mesmo.

Da lei moral como princípio regente do sumo bem

Temos que manter em mente que o princípio da lei moral é um princípio objetivo universal. Ele rege o sistema que progride em relação ao sumo bem, o reino dos fins que une a "felicidade, enquanto ideal da imaginação empírica"48 e que visa a satisfação dos pendores sensíveis, com a virtude, que é o que nos torna dignos de ser feliz. O sumo bem é o objeto da razão pura prática, da vontade pura, mas não seu princípio decisório. ${ }^{49} \mathrm{O}$ sumo bem não determina a ação moral, antes é o fim que se confunde com o princípio. O princípio, ou seja, a lei moral, é um só e puro, independente de fim. O sumo bem é um resultado natural do agir moral, mas não pode ser condicionante deste agir. A ação moral se dá exclusivamente pelo respeito à lei.

Em verdade, somos membros legisladores de um reino da moralidade, possível ante a liberdade, proposto pela razão prática em relação a nós, mas, contudo, somos ao mesmo tempo, súditos e não o mandante do mesmo, sendo já o desconhecimento da nossa posição subalterna como criaturas e a rebelião da presunção contra a autoridade da santa lei um abandono da mesma consoante ao espírito, ainda quando cumpríssemos a letra à risca. ${ }^{50}$

Novamente nos deparamos com um diálogo interno que supera um possível dualismo de antagonismos entre nossa parcela legisladora (Wille) e executória (Willkür), que podemos relacionar respectivamente ao homo noumenon e ao homo phaenomenon. A consonância ao espírito representa a

\footnotetext{
${ }^{47} \mathrm{KpV} 129$

${ }^{48}$ Vocabulário Kant - p.72/73

${ }^{49} \mathrm{KpV} 141$

${ }^{50} \mathrm{KpV} 147$
} 
moralidade, enquanto o cumprimento da letra $\mathrm{a}$, mera legalidade. E o que buscamos é justamente realizar nossas ações consoantes ao espírito, é agirmos moralmente. Precisamos, para avançarmos em nossa hipótese, uma vez estabelecida a necessária pureza da lei moral como motor, compreender o que afinal é a Selbstliebe. Ora traduzida por amor-próprio, mais ligada ao termo Eigenliebe $^{51}$, e à presunção com seu termo Eigendünkel, ora por amor de si, quando se trata do si enquanto animal racional, ora por amor a si, quanto tratamos estritamente de nossa animalidade ${ }^{52}$, a Selbstliebe pode ser um caminho para a garantia da ação moral, um poderoso meio para o princípio da lei moral.

\section{1}

\section{0 que é Selbstliebe?}

É na Crítica da razão prática que Kant define pela primeira vez o termo Selbstliebe.

A união de todas as inclinações (que podem ser trazidas a um sistema tolerável, ao qual se denominaria felicidade) constitui o egoísmo (solipsismus). É este o do amor de si mesmo (Selbstliebe), de uma benevolência excessiva para consigo mesmo (philautia) ou da satisfação de si mesmo (arrogantia). Aquele denominamos particularmente amor-próprio (Eigenliebe) e este presunção (Eigendünkel). ${ }^{53}$

Kant define o amor de si mesmo (Selbstliebe) equiparando-o ao egoísmo, um sistema tolerável que visa à felicidade própria. Divide o amor de si mesmo em excessiva benevolência consigo mesmo - ao qual atribui o termo amorpróprio [Eigenliebe] - satisfação de si mesmo, ao qual chama também de presunção [Eigendünkel]. Infere-se aqui, pela primeira vez na obra do Mestre de Königsberg, uma distinção entre Selbstliebe e Eigenliebe, traduzidos por Rodolfo Schaefer respectivamente por amor de si mesmo e amor-próprio. Segundo esta passagem, Selbstliebe é composta por Eigenliebe e Eigendünkel, ou seja, o amor de si mesmo é composto pelo amor-próprio e pela presunção.

\footnotetext{
${ }^{51} \mathrm{KpV} 129$

${ }^{52}$ Religion B19

$53 \mathrm{KpV} 129$
} 
Da abertura à moral no amor de si

Ao separar aquilo que sofre apenas dano para se conformar à lei, daquilo que é aniquilado por ser contrário a esta, Kant abre espaço para o cultivo racional do amor de si mesmo (Selbstliebe). Kant prossegue argumentando como a lei moral atua sobre a Selbstliebe, o amor de si mesmo, cultivando-a, ao disciplinar a Eigenliebe, o amor-próprio, e aniquilar o Eigendünkel, a presunção. A partir desta obra, especificamente desta citação, começa a fazer sentido ficar atento ao valor de uso dos termos em questão, tanto na leitura no original, quanto nas traduções.

\begin{abstract}
A razão prática pura apenas causa dano ao amor-próprio na medida em que ela o limita - enquanto natural e ativo em nós ainda antes da lei moral - apenas à condição de concordância com esta lei, em cujo caso então ele denomina-se amor de si racional. Mas ela com certeza abate a presunção, na medida em que todas as exigências de autoestima que precedem a concordância com a lei moral são nulas e totalmente ilegítimas, na medida precisamente em que a certeza de uma disposição que concorda com essa lei é a primeira condição de todo o valor da pessoa (como logo o esclareceremos melhor), e toda impertinência ante a mesma é falsa e contrária à lei. Ora, a propensão à autoestima co-pertence às inclinações, com as quais a lei moral rompe, na medida em que a autoestima depende meramente da moralidade. Portanto, a lei moral abate a presunção. ${ }^{54}$
\end{abstract}

O amor de si mesmo recebe da razão pura prática limites justos e correspondentes à lei moral, passando a ser chamado de amor-próprio racional [vernünftige Selbstliebe]. Vemos como as traduções não auxiliam, pois traduzem os termos de forma variada até mesmo no mesmo trecho. A tradução correta, para manter a forma original proposta pelo autor, é amor de si mesmo racional [vernünftige Selbstliebe] e não amor-próprio racional, que implicaria, pelo padrão de tradução estipulado na citação anterior, no original se tratar de vernünftige Eigenliebe, o que não é o caso. Kant explicitamente não usa o termo, tornando racional a Selbstliebe e não a Eigenliebe; a hipótese é que ao racionalizar e moralizar a Selbstliebe, Kant guarda o espaço que antes era da presunção, ou seja, a arrogância da satisfação consigo mesmo, para dar vazão à verdadeira estima de si mesmo, à autoestima moral. Afinal, a lei moral só combate o que assenta na sensibilidade. Ao redigir assim esta afirmação, Kant abre espaço para a compreensão de uma estima moral do ser, pois a razão provoca dano enquanto essa estima só assenta na sensibilidade. Um caminho para, através

\footnotetext{
${ }^{54} \mathrm{KpV} 129$
} 
do cultivo da Selbstliebe, se atingir a Selbstschätzung (autoestima), pela via da Selbstzufriedenheit (autocontentamento virtuoso).

Da tendência egoísta do amor de si

Se racionalizasse apenas a Eigenliebe, moralizar-se-ia apenas o amorpróprio enquanto benevolência consigo mesmo, retirando-lhe apenas o excesso que está em desacordo com a lei e que pode abrir caminho para uma tendência egoísta.

Esta tendência (Hang) de se fazer de si mesmo, segundo os fundamentos objetivos da determinação do seu arbítrio, o fundamento objetivo da determinação da vontade em geral, pode denominar-se de amor de si mesmo [Selbstliebe], o qual, em se tornando legislador é princípio prático incondicionado, pode chamar-se presunção [Eigendünke]. ${ }^{55}$

Ressalta-se neste trecho a tendência (Hang) que temos em desenvolver o amor de si mesmo (Selbstliebe) ao tornar o si mesmo (Selbst) um princípio (fundamento objetivo) da determinação da vontade geral (razão prática) a partir do fundamento objetivo do arbítrio, subordinando a objetividade universal à objetividade de determinadas condições. Vale destaque também o fato da presunção (Eigendünkel) acontecer quando tornamos o amor de si mesmo (Selbstliebe) legislador e princípio prático incondicionado. É mister pontuar que o bem incondicionado que determina em primeiro lugar o que é absolutamente bom em si e fundamenta a máxima da vontade pura em todos os sentidos, atendendo a todos na liberdade que nos rege, só se apresenta aos objetos da vontade depois da determinação da lei moral.

Pois bem: a lei moral, que só é verdadeira (em todo o sentido) como objetiva, exclui totalmente o influxo do amor a si mesmo sobre o princípio prático supremo, inferindo à presunção, que prescreve como leis as condições subjetivas do amor a si mesmo, um dano infinito. Mas tudo o que infere dano à nossa presunção julgamos uma humilhação. Assim, portanto, a lei moral humilha inevitavelmente todo o homem quando este compara a tendência sensível da sua natureza com aquela lei. Resulta disso que aquilo cuja representação, como motivo determinante de nossa vontade, humilha a nossa consciência, é o que excita (porque é um motivo positivo e determinante) em nós o respeito próprio. Desse modo, portanto, a lei moral é também um fundamento subjetivo do respeito. ${ }^{56}$

\footnotetext{
${ }^{55} \mathrm{KpV} 130$

${ }^{56} \mathrm{KpV} 131$
} 
Do respeito como princípio de conquista sobre si mesmo

Registramos aqui como a lei moral é também fundamento subjetivo, ou seja, a máxima do respeito, bem como a lei moral necessita do amor de si para, ao retirar-Ihe sua força, conquistar para si a autoridade sobre as inclinações.

Pois bem: como tudo o que se situa, nessa objetivação, no amor de si mesmo pertence à inclinação, repousa também, como toda inclinação, nos sentimentos, e, portanto, o que infere dano no amor a si mesmo a todas as inclinações em conjunto tem, por isso mesmo, influência sobre o sentimento por isso, concebemos como é possível compreender a priori que a lei moral, ao excluir as inclinações e a tendência a fazer delas a condição prática suprema, isto é, o amor a si mesmo, de todo o acesso à legislação suprema possa exercer um efeito no sentimento, efeito que por um lado é meramente negativo, sendo por outro - isso em consideração da razão pura prática — positivo, não podendo para isso ser admitida qualquer espécie particular de sentimento com a nominação de prático ou moral, na qualidade de sentimento que precedesse ou que servisse de base à lei moral. ${ }^{57}$

Tudo indica que o fato do amor de si mesmo [Selbstliebe] sofrer dano é o que possibilita a consciência a priori da lei. Se não houvesse o sentimento de humilhação em função do dano causado pela lei moral ao amor de si mesmo, não teríamos conhecimento do poder da lei moral sobre nossas inclinações. $O$ amor de si mesmo é então uma condição da produção ou ao menos do reconhecimento do sentimento moral de respeito.

O efeito negativo sobre o sentimento (do desagrado) é, como todo o influxo sobre o mesmo, e como todo o sentimento em geral, patológico. Mas o efeito da consciência da lei moral, consequentemente correlato com uma causa inteligível, a saber, o sujeito da razão pura prática, como suprema legisladora, designamos certamente assim a esse sentimento de um ser racional afetado por inclinações, humilhações (desprezo intelectual), mas, em relação com o fundamento positivo da humilhação, com a lei, chama-se, ao mesmo tempo, respeito a essa lei; para esta lei não há lugar em qualquer sentimento, a não ser no juízo da razão, quando a lei afasta do caminho a resistência, sendo então a remoção do obstáculo tida como igual a um impulso positivo da causalidade. Por isso, pode este sentimento ser denominado agora também um sentimento de respeito para com a lei moral, embora por esses dois fundamentos em conjunto possa ser denominado um sentimento moral..$^{58}$ 
Como já vimos, o amor de si mesmo [Selbstliebe] é cultivado pela razão pura prática, ou seja, pela vontade, na medida em que passa a ter limites justos e conformes à lei e se torna em amor de si mesmo racional [vernünftige Selbstliebe] após ter sua parcela de presunção [Eigendünkel] aniquilada, em um processo que preserva as inclinações conformes à lei e aniquila as contrárias à lei. Podemos levantar a hipótese segundo a qual o sentimento moral estaria intrinsecamente ligado ao amor de si mesmo racional, sendo, portanto, a manifestação do respeito do amor de si racional para com a lei moral. O respeito, essa capacidade de tomar interesse pela lei, é criado pela razão ao inferir prejuízo ao amor de si mesmo. O sentimento moral e o amor de si racional são produtos de uma mesma ação moral, respectivamente de aniquilamento da presunção, que gera o sentimento moral, e de dano, que gera o amor de si racional. O respeito emerge de um amor de si racionalizado e é um tributo que não podemos negar o mérito, interesse designado pela lei prática da razão e que nos leva além de nós mesmos ao encontro de nossa natureza sublime.

Esse sentimento (sob a designação de sentimento moral) é, portanto, produzido somente pela razão. Não serve para julgar as ações nem para fundamentar a própria lei moral objetiva, mas apenas de motor para desta lei, em si mesma, erigir a máxima. ${ }^{59}$

\section{Da relação entre o respeito e o amor de si mesmo}

O respeito e o amor de si racional, nascidos do mesmo movimento da razão, quando a vontade, razão pura prática, humilha a presunção excitando à consciência moral, servem respectivamente de motor e combustível para erigirmos nossa máxima a partir da lei. O respeito, enquanto motor, cujo termo em latim elater animi pode ser compreendido como elevador mental ou ainda elevador do ânimo, eleva nosso interesse ao seu ápice que é a lei; o respeito é a moralidade em si, motor da lei. O amor de si racional, enquanto combustível, é um incentivo prático-moral, pois tem seus limites justos e correspondentes à lei, visando portanto conjugar sua felicidade sob a obrigação do dever, como possível resultante da virtude. Devemos pontuar que a ação virtuosa não garante a felicidade, apenas nos torna dignos desta. A ação deve, portanto, se focar nos princípios morais, sem temer ou esperar resultados, pois isto seria deixar a influência sensível macular a pureza da ação. A lei moral da razão pura

\footnotetext{
${ }^{59} \mathrm{KpV} 135$
} 
prática aniquila a presunção e suas pretensões de estima de si mesmo baseadas na sensibilidade e passa a ser objeto de respeito e princípio desse sentimento positivo conhecido a priori e causado intelectualmente: o respeito. $O$ respeito, mesmo sendo um sentimento puro, pressupõe a sensibilidade, que é também afetada por sentimentos não puros, ou seja, sentimentos de origem empírica, que têm a ver com as inclinações, algumas conformes, como a compaixão, outras contrárias à lei, como a ganância. Limita-se as primeiras, aniquila-se as segundas e tem-se o amor de si racional através do respeito que emerge da lei moral enquanto sentimento moral causado intelectualmente. Quanto às inclinações, são boas por si sós, mas não pertencem de fato à moral, não precisam ser aniquiladas por inteiro, mas domadas e cultivadas para convergirem juntas em um todo chamado felicidade ${ }^{60}$. Há uma aparente contradição desta referência trazida do livro Religion com a citação oriunda da $\mathrm{KpV}$, que ocorre talvez devido à distância no tempo em que foram concebidas por Kant. Todavia, não é nosso intento problematizar esta aparente contradição, mas fazer uso desta dentro do interesse desta dissertação. Afinal, se não houvesse mais inclinações, teríamos uma vontade santa e não haveria mais nada que devesse respeito à lei. O que ocorre é que todos os impulsos sensíveis são excluídos do princípio determinante, mas apenas os contrários à lei sofrem dano, ou seja, são aniquilados. Se não houvesse espaço para os demais impulsos dentro de um modo de ação moral não seriam os impulsos em conformidade com a lei também passíveis de dano? A vontade determinada pela lei moral aniquila as inclinações e máximas contrárias, mas poupa os demais impulsos em conformidade com a lei, sendo estes possíveis de serem usados nos estritos limites da lei não como princípio determinante das máximas, mas como sustentadores da ação moral. Sustentadores da ação moral no sentido de reforçarem a força da lei ao respeitarem seus limites e servirem de motivo de felicidade consequente da ação moral oriunda da virtude de fazer da lei seu princípio e meio de realização, sendo tanto princípio objetivo (lei), quanto princípio subjetivo (máxima).

A lei moral, assim como ela mediante a razão pura prática é fundamento determinante formal da ação e, assim como ela, em verdade, é também fundamento determinante material, mas somente objetivo, dos objetos da ação sob o nome de bom e mau, do mesmo modo ela também é fundamento determinante subjetivo, isto é, motivo para essa ação, na medida em que ela tem influência sobre a moralidade do sujeito e provoca um sentimento que é favorável à influência da lei sobre a vontade. Não há aqui no sujeito nenhum

\footnotetext{
${ }^{60}$ Religion B109
} 
sentimento antecedente que tendesse à moralidade. Pois isto é impossível, uma vez que todo o sentimento é sensível; o motivo da disposição moral, porém, tem que ser livre de toda condição sensível. Muito antes, o sentimento sensorial que funda todas as nossas inclinações é, na verdade, a condição daquela sensação que chamamos de respeito, mas a causa da determinação desse sentimento encontra-se na razão prática pura e por isso esta sensação não pode, em virtude de sua origem, chamar-se de patologicamente produzida e sim de praticamente produzida; $[\ldots]^{61}$

Registremos que o motivo da disposição moral tem que ser livre de toda condição sensível, característica na qual o amor de si racional se encaixa plenamente, o que confere plausibilidade à nossa hipótese de que o amor de si racional dispõe ao progresso moral. Outro ponto importante a ser ressaltado para respaldar nossa abordagem é o fato de o sentimento sensorial, que funda as inclinações, ser condição para o sentimento de respeito. Afinal, afirmamos que é graças ao amor de si, para o qual todas as inclinações convergem, que somos capazes de sentirmos o respeito à lei na medida em que este amor de si sofre dano e torna-se amor de si racional. Ademais, elucidemos alguns termoschave para a compreensão desta passagem: fundamento formal é a lei que determina as diretrizes do dever a partir da razão. O fundamento formal se aplica sem interferência dos objetos do mundo sensível, sendo assim também fundamento material. Ou seja, ao trazer os princípios puros à prática, a razão estabelece objetivos para o empírico, relativizando segundo a moral determinada, os valores de bom e mau, sendo assim fundamento subjetivo da determinação, ou seja, a máxima que determina a ação. A justificativa da moralidade do sentimento moral se encontra em sua origem. Ao ser produzido pela aplicação da razão pura prática a partir da lei, configura-se como uma sensação praticamente efetuada e não patológica. O sentimento moral é criado pela vontade suprassensível e não emerge como uma reação sensível.

[...] como a representação da lei moral usurpa ao amor de si mesmo o influxo e à presunção a ilusão, é diminuto o obstáculo que se depara à razão pura prática, produzindo-se no juízo da razão a representação da superioridade de sua lei objetiva, acima dos impulsos da sensibilidade, resultando, portanto, no aumento do peso da lei de um modo relativo (em consideração de uma vontade afetada pelos impulsos sensíveis) mediante a supressão do contrapeso. ${ }^{62}$

Vimos nesta passagem a gênese do amor de si racional e do respeito à lei. A lei no ser humano se encontra com a necessidade do amor de si mesmo e, a partir deste, afirma seu peso e estatura, apossando-se da influência do amor

\footnotetext{
${ }^{61} \mathrm{KpV} 133 / 134$

${ }^{62} \mathrm{KpV} 133 / 134$
} 
de si, como combustível, e da ilusão da presunção, como motor. A lei reduz, através da concomitante geração do respeito e conversão do amor de si mesmo em racional, o obstáculo à razão pura prática, impulsionando-a mediante a mudança de representação que impacta na vontade afetada pelos impulsos sensíveis.

Desse modo, o respeito para com a lei não constitui motor para a moralidade, mas sim a própria moralidade, considerada subjetivamente qual motor, porque a razão pura prática, ao deitar por terra todas as pretensões do amor a si mesmo em oposição a ela, proporciona autoridade (Ansehen) à lei, que só agora tem influência. Deve-se notar agora nisso que, assim como o respeito é um efeito sobre o sentimento, portanto também sobre a sensibilidade de um ser racional, tal respeito presume essa sensibilidade e, assim, também o caráter finito daqueles seres a quem a lei moral impõe respeito, não podendo atribuir respeito para com a lei a um ser supremo ou também a um ser livre de toda a sensibilidade, para o qual, não pode, todavia, esta constituir qualquer obstáculo da razão prática. ${ }^{63}$

Registra-se que "é o sentimento sensível (sinnliche Gefühl) o que se encontra como fundamento de todas as nossas inclinações e a condição de todo o sentimento a que denominamos respeito"64 ou seja, é no âmbito do sentimento fenomênico que a lei inscreve seu respeito. E qual o maior representante do sentimento fenomênico que o ego, cujo amor de si é a convergência de suas inclinações a um plano imediatista-fenomênico de felicidade, comumente obstáculo à felicidade moral-virtuosa do sumo bem?

Pretendemos assim ter evidenciado a Selbstliebe, o amor de si, ser a condição do reconhecimento da lei moral enquanto ela têm seus objetivos fenomênicos humilhados, suas pretensões terraplanadas para abrir caminho à autoridade da lei, justamente por que "toda diminuição de obstáculos de uma atividade age como fomento dessa mesma atividade" ${ }^{65}$. Vemos então que a relação entre a Selbstliebe e a moral não é tão óbvia assim como uma rápida ou tendenciosa leitura pode indicar e não deve ser entendida de outra maneira senão sob a perspectiva crítica de contraposição de opostos em busca da "porta estreita que conduz à doutrina da sabedoria"66. A perspectiva crítica de contraposição de opostos é uma abordagem que elucidaremos no terceiro capítulo, após termos entendido a aparente contradição que o termo Selbstliebe

\footnotetext{
${ }^{63} \mathrm{KpV} 133 / 134$

${ }^{64} \mathrm{KpV} 133 / 134$

${ }^{65} \mathrm{KpV} 140$

${ }^{66} \mathrm{KpV} 292$
} 
traz consigo, sendo ora colocado como fonte de todo mau, ora como disposição originária para o bem.

\section{2 \\ Fonte de todo mau}

O mau não é a felicidade, à qual todos os seres almejam, mas o meio pelo qual se busca realizar a felicidade, a hierarquia da subordinação das máximas. A maior de todas as reflexões deveria então ser a de que a verdadeira felicidade só é possível na liberdade da razão que atende todos os anseios por felicidade e gera assim, a partir de uma lei, a ordem que a todos atende. Isto garante a possibilidade do sumo bem, onde a felicidade é lastreada pela virtude. Eis o preceito do pensar moral: a consonância de todas as máximas com a lei moral, única condição objetiva da felicidade. A liberdade impõe as próprias garantias para esta consonância, servindo como um princípio regulador que cultiva a felicidade pela virtude: não se deve agir de maneira a impedir sua própria continuidade ou a co-existência de outras ações morais oriundas de outros anseios. Isto gera um sistema de cultivo racional dos anseios com vistas ao sumo bem, abdicando-se de seguir a cegueira de toda e qualquer inclinação irracional que não observa o tempo certo e as condições propícias para realizarse felicidade. A liberdade fornece a razão que orquestra tempo e espaço, ou seja, organiza as intuições internas e externas para que a ação moral seja possível e se possa progredir ao sumo bem, colocando-se como princípio a lei e como meio a virtude, abrindo-se mão da felicidade como resultado almejado, relegando-a como expectativa de consequência desejada e plausível, mas que, sob hipótese alguma, pode influenciar a ação. A lei é o princípio da razão que torna possível o diálogo e entendimento das e entre as inclinações, fazendo da turba cega um interlocutor razoável tanto no âmbito do indivíduo, cuja razão pura prática determina a subordinação e hierarquia de suas inclinações, quanto no coletivo, onde a razão possibilita, a partir de sua comunicabilidade, o entendimento dos indivíduos. É como se víssemos no exterior refletido a relação fenômeno-noumeno do interior de cada indivíduo. Como potencializar a interação de máximas e inclinações à moralidade? Como unir em si máximas e inclinações imediatamente com a consciência de sua existência no mundo externo dos sentidos e no mundo interno de sua personalidade? O que faz a ponte da consciência unir as margens externas e internas de cada um, 
conferindo-lhe unidade e coerência? A resposta é a pureza da lei moral, a concepção teórica de uma ideia sustentável que idealizamos na prática e aplicamos em nossas ações empíricas como um princípio determinante de nossas máximas à moralidade. Kant reforça incessantemente que devemos agir por dever:

\begin{abstract}
Edificante é praticar o bem para com os homens, por amor dos mesmos e por benevolência compassiva, ou ser justo por amor à ordem, mas esta, todavia, não é a genuína máxima da moral de nossa conduta, adequada à nossa situação entre seres racionais, como homens, se não tivermos a pretensão, como se fôssemos soldados voluntários, de elevarmo-nos acima do sentido do dever com a mais orgulhosa das ilusões, pretendendo fazer, independente do mandato, só por uma satisfação pessoal, aquilo para o qual nenhum mandato seria necessário. ${ }^{67}$
\end{abstract}

Do mau como orgulho, arrogância e presunção

Kant adverte contra o orgulho que emerge em pessoas que se julgam acima do dever por não ser este o caminho moral. Se alguém se julga acima da lei e age apenas de acordo com a satisfação pessoal, não utiliza a máxima da moral em sua conduta e está assim inadequado ao convívio humano em sociedade enquanto ser racional que compartilha da comunicabilidade da razão. Podemos imaginar que, se ancorado apenas na satisfação pessoal, facilmente pode haver mudança de postura variando conforme o ânimo e temperamento ou ainda sucumbir-se à arrogância [Eigendünkel] por considerar-se superior. Justamente por isto, é necessário a consciência de que

Encontramo-nos debaixo de uma disciplina da razão e em todas as nossas máximas da subordinação sob a mesma devemos não esquecer que não podemos subtrair-lhe nada, nem diminuir no mais leve que seja a autoridade da lei, ainda que lhe seja esta propiciada pela nossa própria razão com uma ilusão egoísta, colocando o fundamento de determinação da nossa vontade, embora conforme à lei, contudo em lugar diverso da mesma lei e no respeito para com esta lei. Dever e obrigação (Schuldigkeit) são as denominações exclusivas que devemos dar à nossa relação com a lei moral. ${ }^{68}$

De outra maneira, podemos perder-nos em meio à ilusão provocada pela excessiva benevolência para conosco. Daí a importância de estabelecermos

\footnotetext{
${ }^{67} \mathrm{KpV} 146$

${ }^{68} \mathrm{KpV} 147$
} 
como princípio a lei e mantermos fielmente o respeito à mesma, pois em nossa fraqueza reside a ameaça de nos corrompermos e cedermos às inclinações, orquestrando a razão para justifica-las.

\begin{abstract}
A lei moral ia à frente como proibição (Moisés II, 16, 17), como deve ser num homem enquanto ser ainda não puro, mas tentado por inclinações. Ora em vez de seguir sinceramente esta lei como móbil suficiente (o único incondicionalmente bom e em que não tem lugar qualquer escrúpulo), o homem foi em busca de outros motivos (III, 6) que só condicionalmente (a saber, enquanto por eles nenhum dano acontece à lei) podem ser bons e, se se pensar a ação como derivada conscientemente da liberdade, tomou por máxima sua seguir a lei do dever não por dever, mas sempre também em vista de outros propósitos. Por conseguinte, começou a pôr em dúvida o rigor do mandamento que exclui a influência de todo o outro motivo, após com sutilezas rebaixar a obediência a ele a uma obediência meramente condicionada (sob o princípio do amor de si [Selbstliebe] ${ }^{69}$ ) de um meio; a partir de então foi, por último, acolhida na máxima da ação a preponderância dos impulsos sensíveis sobre o móbil derivado da lei, e assim se cometeu o pecado (III, 6). ${ }^{70}$
\end{abstract}

Kant retrata aqui a queda humana por deixar-se seduzir por outros motivos que não o princípio de lei sob o argumento de servirem de impulso e auxílio à lei, mas que desta tiraram o foco e a atenção, portanto, o respeito. Até que, sob o princípio do amor de si condicionou-se a obediência à lei à felicidade pessoal, tornando-nos escravos das inclinações e a própria felicidade refém de si mesma, inviabilizando-a, uma vez que não há felicidade possível sem liberdade, pois há em ambos, felicidade e liberdade, uma noção de progresso, de mudança, até porque:

ressoa sem diminuição na nossa alma o mandamento: devemos tornar-nos homens melhores; devemos, portanto, também poder fazê-lo, inclusive se o que conseguimos fazer houvesse de por si só ser insuficiente e nos tornássemos assim apenas susceptíveis de uma assistência superior para nós imperscrutável. - Importa, sem dúvida, pressupor aqui que um gérmen do bem, que persistiu na sua total pureza, não pôde ser extirpado ou corrompido, gérmen que não pode certamente ser o amor de si; tal amor, aceite como princípio das nossas máximas, é precisamente a fonte de todo o mau. ${ }^{71}$

Do mau como má hierarquia das máximas

O amor de si não é o gérmen do bem, o que não nega o amor de si como disposição para o bem, apenas reafirma a coerência de Kant de não incluí-lo

\footnotetext{
${ }^{69}$ Religion B44

${ }^{70}$ Religion B44

${ }^{71}$ Religion B50
} 
como princípio de nossas máximas. É a má colocação da hierarquia de subordinação das máximas que torna o amor de si fonte de todo mau. Pois vejamos:

\begin{abstract}
Como o amor em geral, assim também o amor de si mesmo se pode dividir em amor de benevolência e amor de complacência (benevolentiae et complacentiae), e ambos devem (como é evidente) ser racionais. Acolher o primeiro na sua máxima é natural (pois quem não quererá que as coisas the corram sempre bem?). Mas este amor só é racional na medida em que, por um lado, no tocante ao fim, se escolhe apenas o que pode coexistir com o maior e mais duradouro bem-estar e, por outro, se escolhem os meios mais aptos em ordem a cada uma das partes constitutivas da felicidade. A razão ocupa aqui unicamente o lugar de uma serva da inclinação natural; mas a máxima que por isso se adota não tem qualquer referência à moralidade. Se, porém, dela se fizer o princípio incondicionado do arbítrio, então é a fonte de um conflito imensamente grande face à moralidade. ${ }^{72}$
\end{abstract}

É neste contexto que Kant reapresenta a divisão do amor de si, idêntica ao do amor em geral. Como na Crítica da razão prática, também na Religion Kant divide o amor de si em amor de benevolência e amor de complacência. Mais do que lhes atribuir os termos de philautia e amor-próprio para a benevolência e arrogância e presunção para a complacência, exatamente como na Crítica, Kant expõe as condições de sua proposta de moralidade e revela que o acolhimento na sua máxima do amor de si benevolente é compatível com o argumento de que todos querem que as coisas the corram sempre bem. A condição de sua proposta de racionalidade é que a escolha de fins ocorra de modo que possa coexistir com o maior e mais duradouro bem-estar e com a escolha dos meios adequados a cada parte constitutiva da felicidade. A racionalidade do amor de si benevolente (philautia/amor-próprio) é uma razão serva da inclinação natural, não tendo a máxima adotada nenhum fundamento moral. Kant adverte que se cria um conflito gigantesco com a moralidade ao fazer do amor benevolente de si o princípio incondicionado de seu arbítrio. Caso isto ocorra, contemplamos a face do mau radicado em nosso coração, tornando mau este primeiro fundamento subjetivo de nossas máximas. Tal qual na Crítica da razão prática, quando a benevolência se torna legisladora, entra em cena a arrogância. Mas há um caminho, mesmo que circular, para a viabilidade do amor de si racional, o amor de si enquanto sujeito moral.

\footnotetext{
${ }^{72}$ Religion B51 nota de rodapé
} 
Do amor de si racional como filtro moral

Primeiro, Kant expõe a armadilha de fazermos das máximas princípios de satisfação da inclinação natural, fazendo assim a razão refém e serva das inclinações, tendo nossas ações no máximo legalidade, mas nunca moralidade.

Ora um amor racional de complacência em si mesmo pode entender-se de modo que nos comprazamos nas máximas, já mencionadas, orientadas para a satisfação da inclinação natural (enquanto aquele fim é alcançado graças ao seu seguimento); e então é o mesmo que o amor de benevolência para consigo próprio; alguém se compraz em si mesmo como um comerciante para o qual foram bem sucedidas as suas especulações mercantis e que, por causa das máximas nelas adotadas, se regozija com o seu bom discernimento. ${ }^{73}$

Em seguida, prossegue demonstrando a possibilidade de um amor de si racional, diretamente ligado ao princípio interno do contentamento que na Crítica da razão prática chamou de Selbstzufriedenheit ${ }^{74}$, o contentamento de si a partir da consciência de sua virtude.

\begin{abstract}
Mas só a máxima do amor a si de complacência incondicionada (não dependente do ganho ou perda como consequências da ação) seria o princípio interno de um contentamento que unicamente nos é possível sob a condição da subordinação das nossas máximas à lei moral. Não pode comprazer-se em si, nem estar sequer sem um amargo desgosto em si próprio um homem, ao qual a moralidade não é indiferente, que é consciente de tais máximas não serem nele consonantes com a lei moral. ${ }^{75}$
\end{abstract}

Kant ressalta que é justamente o amor de si mesmo racional que impede, tal qual filtro de combustível, a mescla de causas do contentamento, garantindo a pureza da autoestima moral a partir da distinção das consequências de suas ações com os motivos impulsores do arbítrio, garantindo assim a pureza destes. Ou seja, focando nos princípios sem se prender aos fins, resultados almejados ou conseguidos.

Este amor poderia chamar-se o amor de si racional que impede toda mescla de outras causas de contentamento, derivadas das consequências das suas ações (sob o nome de uma felicidade por este meio para si conseguida), com os motivos impulsores do arbítrio. ${ }^{76}$

Eis que Kant equipara a ação do amor de si racional ao respeito, o que comprova a emergência concomitante de ambos no ato da razão subjugar o amor de si.

\footnotetext{
${ }^{73}$ Religion B50

${ }^{74} \mathrm{KpV} 212$

${ }^{75}$ Religion B50

${ }^{76}$ Religion B50
} 
Ora bem, visto que tal significa o respeito incondicionado pela lei, porque se quererá, mediante a expressão amor a si mesmo racional, mas moral só sob a última condição, dificultar desnecessariamente a compreensão clara do princípio, andando às voltas num círculo (pois só é possível alguém amar-se a si mesmo de modo moral enquanto é consciente da sua máxima de fazer do respeito pela lei o supremo motivo impulsor do seu arbítrio)? ? $^{77}$

Eis a comprovação da moralidade em meio à divisão do amor de si, mesmo que criticada por Kant por dar voltas em uma lógica circular e não ir direto ao ponto da questão moral. Dentro de seu interesse de ressaltar a pureza do princípio moral tal crítica é necessária por não ir direto ao ponto. Mas para nossa proposta esta argumentação de Kant é fundamental, pois tal círculo é a consciência de si nos estritos limites da lei. Afinal, só é possível alguém amar-se a si mesmo de modo moral enquanto consciente da sua máxima de fazer do respeito pela lei o supremo motivo impulsor de seu arbítrio, tendo sua presunção já sido aniquilada. A consciência desta virtude gera o contentamento moral e a vontade de neste estado permanecer. Em suma, só é possível amar a sua personalidade enquanto esta é exemplo de ideia intelectual de humanidade, ou seja, só é possível amar-se racionalmente de modo moral enquanto se ama o verdadeiro eu, o eu noumênico. O sujeito moral, homo noumenon, que se dispõe as leis e que garante assim a possibilidade de ser digno da felicidade é o que em nós é, também, digno de estima e assim merecedor do amor de si que é racional, posto que consciente de sua moralidade. O amor de si racional traz a reflexão consciente da forma que devemos ter para nos tornarmos exemplos práticos da lei, auxiliando indiretamente na escolha moral das máximas, tendo como limitação a dignidade de ser feliz.

\begin{abstract}
A felicidade, segundo a nossa natureza, é para nós, como seres dependentes de objetos da sensibilidade, o primeiro e o que incondicionalmente desejamos. De acordo com a nossa natureza (se assim se pretender em geral denominar o que nos é inato), enquanto seres dotados de razão e de liberdade, a felicidade não é de longe o primeiro, nem sequer é incondicionalmente um objeto das nossas máximas; mas tal é a dignidade de ser feliz, a saber, a consonância de todas as nossas máximas com a lei moral. Que esta consonância seja objetivamente a condição sob a qual o desejo da felicidade se pode coadunar com a razão legisladora, eis em que consiste toda a prescrição moral; e somente na intenção de desejar com esta condição é que consiste o modo de pensar moral. ${ }^{78}$
\end{abstract}

Se o amor de si sofre a mesma divisão que o amor geral, podemos pensar na definição de amor de Kant como base para uma abordagem do próprio amor de si. Kant define o amor como a livre adoção da vontade alheia

\footnotetext{
${ }^{77}$ Religion B50

${ }^{78}$ Religion B50 - B52 - nota de rodapé
} 
sob sua máxima ${ }^{79}$, um complemento indispensável à imperfeição da natureza humana de ter de ser necessitada para aquilo que a razão prescreve pela lei. Seguindo e aplicando esta lógica do amor ao si mesmo, isto poderia reforçar a compreensão de que nos tornamos dignos de sermos felizes pela maneira racional segundo a qual organizamos nossas máximas de acordo com a lei moral. Isto traz esclarecimento à intenção de desejar, fundando assim um modo de pensar moral baseado no caráter inteligível, que é o modo prático e coerente de pensar segundo máximas imutáveis ${ }^{80}$. O pensar moral a partir de nosso caráter inteligível ocorre a partir da livre adoção, por nossa parcela fenomênica (homo phaenomenon), da lei apresentada por nossa personalidade noumênica (homo noumenon) àquela parcela fenomênica.

Donde se segue que a formação moral do homem não deve começar pela melhoria dos costumes, mas pela conversão do modo de pensar e pela fundação de um caráter; embora habitualmente se proceda de outro modo, e se combata contra vícios em particular, deixando, porém, intacta a sua raiz universal. Ora até o homem mais limitado é susceptível da impressão de um respeito tanto maior por uma ação conforme ao dever quanto mais lhe subtrai no pensamento outros motivos que, mediante o amor de si, pudessem ter influência sobre a máxima da ação; e inclusive as crianças são capazes de encontrar o mais pequeno vestígio de mescla de motivos espúrios, perdendo então para elas a ação instantaneamente todo o valor moral. Esta disposição para o bem é cultivada de modo incomparável e implanta-se paulatinamente no modo de pensar, se se aduzir o exemplo de homens bons (no tocante à sua conformidade com a lei) e se permitir aos aprendizes morais julgar a impureza de algumas máximas a partir dos móbiles das suas ações; de maneira que o dever começa, simplesmente por si mesmo, a adquirir um peso notável nos seus corações. ${ }^{81}$

Mais uma vez podemos ver que é através do amor de si que outros motivos poderiam ter influência sobre as máximas da ação. Contudo, podemos ler também que é justamente através do amor de si que podemos nos tornar conscientes tanto da existência de outros motivos, quanto do valor moral: pretendemos ter comprovado que o amor de si serve de interface para 0 reconhecimento a priori da lei através do sentimento de respeito.

\section{Da importância do caráter}

É justamente na fundação do caráter inteligível através do qual o dever adquire progressivamente consideração em nossos corações - nossa natureza

\footnotetext{
${ }^{79} \mathrm{O}$ fim de todas as coisas - p.13

${ }^{80} \mathrm{KpV} 271$

81 Religion B56
} 
humana, o fundamento primeiro subjetivo das suas máximas -, onde ocorre a verdadeira revolução no modo de pensar: a escolha radical, por amor, de livremente subordinar suas máximas à lei e subordinar a vontade alheia conscientemente a suas máximas. Pensamos por nós mesmos a partir das diretrizes da lei para em seguida pensar no lugar do outro e com satisfação adotar sua vontade que está em alinho com a lei e, enfim, refletimos sobre os distintos pontos de vista do pensamento para, sob os auspícios da lei, pensar em concordância com esta, procedimentos que garantem a autonomia do processo do pensamento moral frente às inclinações. Age-se como um novo homem, um homem moral, a partir da fundação de um bom caráter ${ }^{82}$, um modo prático e coerente de pensar segundo máximas imutáveis que tendenciam ao bem, e de um novo coração ${ }^{83}$, o novo motivo de adoção das máximas sob a lei. Já não se pensa no saciamento imediato, mas inclui-se o saciamento das inclinações conformes à lei em uma perspectiva mais ampla e sustentável através do progresso contínuo.

Ora visto que isto leva somente a uma progressão, que se continua até ao infinito, do mau para o melhor, segue-se que a transformação da disposição de ânimo do homem mau na de um homem melhor se deve colocar na mudança do supremo fundamento interior da adoção de todas as suas máximas segundo a lei moral, na medida em que este novo fundamento (o coração novo) é agora ele próprio imutável. ${ }^{84}$

A mudança do homem é uma reforma progressiva e gradual, como ser finito preso ao espaço-tempo determinado por sua compreensão fracionada. Mas a mudança ocorre de fato de forma revolucionária e radical no momento em que se determina a adoção do princípio moral como fundamento interior da hierarquização das máximas segundo a lei moral. A mudança é fazer o coração pensar com a razão. ${ }^{85}$

Da ordenação no coração

Kant deixa claro que a fonte de todo mau se encontra precisamente no coração. Kant compara o coração à natureza humana ${ }^{86}$ e o conceitua como

\footnotetext{
${ }^{82}$ Religion B54

${ }^{83}$ Religion B61

${ }^{84}$ Religion B61

${ }^{85}$ Ethica Teil B

${ }^{86}$ Religion B21
} 
princípio subjetivo de nossas máximas ${ }^{87}$, o local onde a razão inscreveu a lei ${ }^{88}$. É, portanto, no coração que há a propensão ao mau na a) fragilidade da natureza humana que quer e admite o bem nas suas máximas, mas não as cumpre; na b) impureza do coração, que faz com que a máxima moral seja insuficiente e necessite de outros móbiles para se amparar, fazendo com que a máxima adotada não seja puramente moral; na c) malignidade da natureza humana, que inverte a ordem de subordinação das máximas de um livre arbítrio. Esta inversão advém de outro interesse que não o moral, sendo legal, mas não moral, apenas conforme a lei, o que torna o ser humano, no tocante à sua intenção moral, mau. O mal radical, versão laica do pecado original, turva nossa capacidade de julgar por estar radicado no coração, no princípio subjetivo do qual emergem as máximas, resultando na inversão da ordem das máximas e consequentemente no uso da razão para saciar suas inclinações. Em suma, o mal radical é fazer do amor-próprio [Eigenliebe] seu princípio legislador que se manifesta tanto em a) como permissividade ao desejo das inclinações, cedendo ao prazer, em b) como inconsistência que busca no saciamento das inclinações condições de cumprir a lei e em c) como proveito próprio consciente por inverter a ordem das máximas de seu arbítrio para que se beneficie primeiro.

Aqueles a quem o fundamento de determinação somente formal (da legalidade) em geral no conceito do dever não satisfaz como tal fundamento, admitem, todavia, que este não se pode encontrar no amor a si mesmo, o qual se rege pelo próprio bem-estar. Restam, pois, então apenas dois fundamentos de determinação; um, que é racional, a própria perfeição, e outro, que é empírico, a felicidade alheia. - Ora se pela primeira não entendem já a perfeição moral, que só pode ser uma (a saber, uma vontade que obedece incondicionalmente à lei), caso em que explicariam em círculo, deveriam referir-se à perfeição natural do homem, enquanto ela é susceptível de uma elevação, e da qual muito pode haver [...]. Mas isto é bom sempre de modo condicionado, ou seja, apenas sob a condição de que o seu uso não esteja em conflito com a lei moral (a única que incondicionalmente ordena); por conseguinte, esta perfeição, posta como fim, não pode ser princípio dos conceitos de dever. O mesmo se aplica igualmente ao fim dirigido à felicidade de outros homens. De fato, uma ação deve primeiro ponderar-se em si mesma segundo a lei moral, antes de se dirigir à felicidade de outros. Fomentar esta felicidade é, pois, dever só de modo condicionado e não pode servir de princípio supremo de máximas morais. ${ }^{89}$

Mais uma vez, Kant estabelece claramente que a Selbstliebe não pode ser fundamento moral, por esta reger o próprio bem-estar. Todo bem-estar pressupõe a importância da segurança, necessária para assegurar a existência e assim um possível decorrente bem-estar -, bem como para o estabelecimento da moral, pois onde há fome, medo e insegurança dificilmente se contemplará

\footnotetext{
${ }^{87}$ Religion B61

${ }^{88}$ Religion B116

${ }^{89}$ Religion B IV - nota de rodapé ao prólogo da primeira edição
} 
sua natureza sublime suprassensível que se eleva de sua animalidade e descobre-se livre. Dois pensamentos afloram ao ler a citação acima: 1) a elevação à perfeição moral do homem, apesar de fim, não pode ser princípio ordenador, pois somente a lei moral ordena incondicionalmente; 2) a ação de ponderar-se segundo a lei moral antes de dirigir-se à felicidade alheia revela um caminho lógico importante para a garantia da ação moral, perfazendo o caminho das máximas do senso comum de primeiro pensar por si próprio (a partir da lei), depois de pensar no lugar do próximo e, por fim, de pensar em concordância consigo mesmo e assim em alinho à lei: determina assim a medida da lei como parâmetro prático para lidar com o empírico - algo parecido com o uso do lado (prato) do amor-próprio como medida da balança para ampliação do entendimento humano universal.

O juízo daquele que refuta minhas razões é meu juízo, depois de tê-lo pesado contra o prato do amor-próprio e em seguida [dentro do mesmo prato] ${ }^{90}$ contra minhas supostas razões e de ter encontrado nele uma maior consistência. Antes eu considerava o entendimento humano universal apenas do ponto de vista do meu entendimento: agora ponho-me no lugar de uma razão alheia e externa e observo meus juízos, junto com seus mais secretos motivos, do ponto de vista dos outros. Por certo a comparação de ambas as observações resulta em fortes deslocamentos de posição, mas ela é também o único meio de evitar a ilusão ótica e de pôr os conceitos em seu devido lugar, nos quais se encontram em vista das capacidades cognitivas da natureza humana. ${ }^{91}$

A citação tem como objetivo evitar a ilusão de ótica provocada pela rigidez de pontos de referência parciais que possam vir a se julgar universais, ou seja, ela antecipa as máximas do senso comum e revela uma maneira de ampliar o ponto de vista do ser humano e alargar sua mentalidade, condições fundamentais para a moralidade de toda ação quanto à constituição das máximas universalizáveis. Impossível não lembrar da citação do Conflito das faculdades, publicado por Kant em 1798:

Talvez o fato de o curso das coisas humanas nos parecer tão absurdo também dependa de nossa má escolha do ponto de vista a partir do qual o consideramos. Os planetas, vistos da Terra, ora seguem um curso retrógrado, ora param, ora prosseguem. Porém, se o ponto de vista é tomado a partir do Sol, o que apenas a razão pode fazer, os planetas seguem continuamente, de acordo com a hipótese de Copérnico, seus percursos regulares. [...] Mas é infelicidade nossa não sermos capazes de nos colocar desse ponto de vista, quando se trata de

\footnotetext{
${ }^{90}$ Sugestão de complemento de tradução para contemplar o termo in derselben, referente ao prato da balança, em alemão chamado no texto como Schale e deixado de fora na tradução brasileira.

${ }^{91}$ Escritos pré-críticos p.185/186
} 
predizer ações livres. Pois seria o ponto de vista da Providência, situado fora de toda sabedoria humana, que se estende às ações livres do homem, ações essas que obviamente podem ser vistas por ele, mas não previstas com certezas. ${ }^{92}$

De certo, vale ressaltar que já se busca nos Sonhos, de 1766, a revolução copernicana considerada na perspectiva da filosofia prática: sair-se, em sua jornada de esclarecimento, de seu falso centro - a Terra - sua natureza fenomênica, lugar das inclinações, para alcançar o centro próximo - o Sol nossa razão, natureza noumênica. $O$ deslocamento de perspectiva gera ampliação da consciência, principalmente sobre seus juízos e motivos secretos, possibilitando-nos através da comunicabilidade de nossas sublimes intenções, tornarmos belas nossas ações. Ou seja, através daquilo que conseguimos compreender de nossas intenções, dinâmicas e imensamente grandes, tornar racionais e, portanto, comunicáveis nossas ações. Kant utiliza como lado referencial da balança o amor-próprio sendo o julgamento alheio primeiro contra meu amor-próprio, depois em concordância com este, alargando o mesmo quanto à sua consistência e entendimento da universalidade, indo além de mim mesmo. Por se tratar da ampliação do entendimento universal fica claro que não se trata aqui do alargamento do amor-próprio enquanto amor às suas inclinações, mas antes do aumento de consistência das razões do meu amorpróprio. Coloca-se, assim, os conceitos em seus devidos lugares e agrega-se valor ao entendimento pelo grau de universalidade que adquire meu ponto-devista ao qual minha estima está diretamente atrelada. Kant sugere esta troca de posição para elucidar as perspectivas como uma maneira de evitar ou ao menos revelar partidarismos. Ao colocar em oposição o amor-próprio e a visão alheia, não somente os reduz, mas também busca inserir ambos em um mesmo contexto ao medir o julgamento alheio a partir do lado do mesmo amor-próprio. Podemos entender o amor-próprio como medida inicial do entendimento humano universal a ser superado, confirmado, suspenso ou determinado no diálogo com as demais perspectivas do mesmo entendimento, rumando progressivamente à universalidade desse entendimento. Parece tratar-se do mesmo movimento que realizam as máximas do senso comum e que nos oferecem um caminho para superar a preguiça e a covardia que ajudam no estabelecimento do mau: pensar por si mesmo, pensar no lugar do outro, pensar em concordância consigo

\footnotetext{
${ }^{92}$ Conflito das faculdades, p.102
} 
mesmo. ${ }^{93}$ Movimento similar ao que Kant nos apresenta no texto "Disposição Originária para o bem na Natureza Humana"94 da Religion. Há, portanto, uma possibilidade de sair da menoridade, que é responsabilizar-se por si mesmo partir de seu pensamento, tendo como senhor a lei. E a garantia desta possibilidade da superação do mau é que o mesmo amor de si que é responsável pelo mau ao ser utilizado como princípio determinante, é também disposição originária para o bem - por um lado, pela natureza humana estar determinada a poder aspirar ao sumo bem ${ }^{95}$, por outro, pelo amor de si racional estar natural e vivo em nós ainda antes de manifestar-se ${ }^{96}$.

\section{3 \\ Disposição original para o bem}

Disposição [Anlage] em Kant, significa, como lemos na Religion

Por disposições de um ser entendemos tanto as partes constituintes para ele requeridas como ainda as formas da sua conexão para ser semelhante ser. São originárias, se pertencem necessariamente à possibilidade de um tal ser; e contingentes, se o ser for possível também sem elas. Importa ainda observar que aqui não se fala de nenhumas outras disposições exceto das que imediatamente se referem à faculdade de desejar e ao uso do arbítrio. ${ }^{97}$

E como o próprio título "Disposição Originária para o bem na Natureza Humana" dispõe e o texto confirma, Kant atrela o amor de si [Selbstliebe] às disposições originárias para o bem na natureza humana, tripartindo tal disposição quanto ao seu fim em três elementos da determinação do humano: animalidade, humanidade e personalidade. Veremos a seguir cada uma delas, buscando compreender por que tal disposição originária do amor de si ao bem pode voltar-se ao mau e em que medida alarga o entendimento humano, servindo de passagem ${ }^{98}$ para o progresso da natureza humana.

\footnotetext{
93 KU B158

${ }^{94}$ Religion B16

${ }^{95} \mathrm{KpV} 264$

${ }^{96} \mathrm{KpV} 129$

${ }^{97}$ Religion B19

98 Passagem é uma noção central nos escritos dos últimos anos da vida de Kant e trata da passagem da natureza para a liberdade, que ocorre pela "autoafecção do sujeito constituindo o objeto [...] entendida como autodeterminação" - Vocabulário Kant.
} 


\title{
Por amor a si
}

\section{A começar pela}

I) disposição para a animalidade do homem como ser vivo;

\begin{abstract}
A disposição para a animalidade no homem pode pôr-se sob o título geral de amor a si mesmo físico e simplesmente mecânico, i.e., de um amor a si mesmo para o qual não se requer a razão. É tríplice: primeiro, em vista da conservação de si próprio; em segundo lugar, em ordem à propagação da sua espécie por meio do impulso ao sexo e à conservação do que é gerado pela mescla com o mesmo; em terceiro lugar, em vista da comunidade com outros homens, i.e., o impulso à sociedade. - Em tal disposição podem enxertar-se vícios de todo o tipo (os quais, porém, não brotam por si mesmos daquela disposição como raiz). Podem chamar-se vícios da brutalidade da natureza e denominam-se, no seu mais intenso desvio do fim natural, vícios bestiais: os vícios da gula, da luxúria e da selvagem ausência de lei (na relação a outros homens). ${ }^{99}$
\end{abstract}

$\mathrm{Na}$ disposição à animalidade, trata-se de um amor a si mesmo físico e simplesmente mecânico para o qual não se requer uso de razão alguma. Kant Ihe atribui três qualidades fundamentais à nossa existência - sem as quais não seria possível pensar nossa moralidade por esta necessitar de uma existência segura e que podem ser compreendidos como degraus que elevam o indivíduo à sociedade: a) autoconservação; b) conservação da espécie pelo impulso sexual; c) impulso à sociedade. Há, se observarmos atentamente, uma noção de progresso a partir da segurança: primeiro se garante a conservação da unidade, do indivíduo, em seguida expande-se o indivíduo através da união com outro, resultando em uma propriedade que emerge em um terceiro, o que, todavia, é uma ação de segurança para a espécie; por fim, garante-se tanto a segurança do indivíduo, quanto da espécie pelo impulso do amor de si à sociedade. O que temos é que o amor de si mesmo enquanto animalidade garante tanto a existência, quanto a comunicabilidade desta mesmo que unida no nível da sobrevivência e sem racionalidade alguma. Lança assim, todavia, as condições necessárias para a emergência da humanidade através da conscientização que ocorre necessariamente a partir dos impulsos mecânicos. Ganha-se consciência através do movimento, do deslocamento de perspectiva e da reflexão sobre suas consequências; o que vimos quando tratamos do movimento do pensamento nas máximas do senso comum. Há, contudo, a possibilidade de se adquirir vícios. Kant explicita a impossibilidade de tais vícios brotarem por si mesmos da disposição como raiz: os vícios da gula, da luxúria e da selvagem ausência da lei na relação com outros humanos, chamados de vícios bestiais por seu mais

\footnotetext{
${ }^{99}$ Religion B16
} 
intenso desvio do fim natural. O motivo pelo qual Kant atribui tais vícios como enxerto, não como originários na raiz da disposição, pode residir no próprio conceito apresentado: como o amor de si é a disposição à segurança individual e da espécie, conflitaria com a sua natureza de intenção e seu conceito atribuirIhe algo nocivo a si mesmo; tais vícios devem ter espaço precisamente na falta do amor a si, na medida desregrada que se perde de seu próprio fim natural e, ao invés de caminhar com a liberdade que a segurança nos promete, se prende a excessos talvez por medo da escassez ou ansiedade imediatista: age justamente de modo a criar aquilo que teme, pois age irracionalmente e sem o amor a si. A reflexão final é que enquanto não há o uso da razão, é o amor a si que conduz nosso progresso do individual ao coletivo, da autoconservação à sociedade humana, indo para além do animal, levando-nos para além de nossa animalidade rumo à concepção do uso de nossa razão. Da animalidade à paz perpétua, um progresso constante que nos afasta de nossa animalidade e aproxima da ideia que, mesmo que não seja realizável, nos impulsiona à excelência do uso de nossa razão e auxilia na edificação moral.

Por amor a nós

\section{O segundo estágio no progresso da natureza humana é}

2) A sua disposição para a humanidade enquanto ser vivo e racional,

As disposições para a humanidade podem referir-se ao título geral do amor de si, sem dúvida, físico, mas que compara (para o que se exige a razão), a saber: julgar-se ditoso ou desditado só em comparação com outros. Do amor de si promana a inclinação para obter para si um valor na opinião dos outros; e originalmente, claro está, apenas o da igualdade: não conceder a ninguém superioridade sobre si, juntamente com um constante receio de que os outros possam a tal aspirar; daí surge gradualmente um desejo injusto de adquirir para si essa superioridade sobre outros. - Aqui, a saber, na inveja e na rivalidade podem implantar-se os maiores vícios de hostilidades secretas ou abertas contra todos os que para nós consideramos estranhos, vícios que, no entanto, não despontam por si mesmos da natureza como de sua raiz, mas, na competição apreensiva de outros em vista de uma superioridade que nos é odiosa, são inclinações para alguém, por mor da segurança, a si mesmo a proporcionar sobre outros, como meio de precaução: já que a natureza só queria utilizar a ideia de semelhante emulação (que em si não exclui o amor recíproco) como móbil para a cultura. Os vícios que se enxertam nesta propensão podem, pois, denominar-se também vícios da cultura; e no mais alto grau da sua malignidade (pois então são simplesmente a ideia de um máximo de mau, que ultrapassa a humanidade), por exemplo, na inveja, na ingratidão, na alegria malvada, etc., chamam-se vícios diabólicos. ${ }^{100}$ 
Nas disposições à humanidade, o amor de si, além de físico como o da animalidade, é também racional na medida em que usa a razão para a comparação: ser feliz ou infeliz em comparação com outros. Desse amor de si emerge a inclinação para obter para si um valor na opinião dos outros e pode haver a tendência de se ficar refém da necessidade imediata de felicidade, sensação fragilizada na comparação com a felicidade alheia. Kant insiste em que, originalmente, este valor seja o da igualdade: não conceder a ninguém superioridade sobre si, pois há um valor absoluto do ser humano, sua dignidade, a humanidade presente em si, em suma, sua liberdade de se colocar fins ${ }^{101}$. Há aqui, contudo, também armadilhas, apontadas por Kant: ao recear que outros possam aspirar a uma superioridade sobre nós, surge gradualmente o injusto desejo de adquirir para si tal superioridade sobre outros. Mais uma vez, vemos o medo provocado pela insegurança levar a um vício e ação nociva de inveja e rivalidade que produzem hostilidades secretas ou abertas contra todos os que para nós consideramos estranhos e que, registre-se, são implantadas, e não, originárias da disposição, são vícios da cultura, chamados em seu mais alto grau de vícios diabólicos, pois fazem uso da razão para justificar qualquer distorção. Emergem de uma competição apreensiva por superioridade, inclinação que surge por motivo de segurança, buscando-se ser superior como meio de precaução. Kant ressalta que a competição emulada pela natureza não exclui o amor recíproco, que Kant infere à amizade na Doutrina da Virtude, apenas utiliza a noção de competição como móbil para o cultivo humano. Trata-se de uma maneira racional de autoconservação já não mais meramente física e animal, mas também psicossocial. Talvez possa se afirmar aqui um elo de ligação entre o amor de si e o amor à honra, outro nome que Kant dá à virtude ${ }^{102}$. Kant afirma inclusive que todas as ações virtuosas emanam do amor à honra, compreendido a partir deste ponto como amor à honra pela humanidade que igualmente representamos em nossos atos.

Por amor à honra de representarmos a humanidade em nossos atos

Agir por amor à honra pode-nos levar à próxima disposição, a da personalidade, ao tomarmos como medida a lei moral que nos eleva, enquanto que se agirmos meramente por amor de si, podemos ficar presos na

${ }^{101}$ Dieter Schönecker proferiu uma palestra sobre o tema Valor (Wert) e Dignidade (Würde) na PUC-Rio, em setembro de 2014.

${ }_{102}$ TL 420 
comparação horizontal com o outro, ficando ambos reféns de nossos dados fenomênicos. Observa-se aqui também uma noção de progresso: uma vez estabelecida a sociedade humana pela disposição animal, avança-se à humanidade pelo entendimento da igualdade que nos une, a saber, a razão e sua comunicabilidade, não conflitantes, antes reforços do amor recíproco. Voltaremos a tratar do amor recíproco no terceiro capítulo. Por enquanto, é necessário estabelecer o entendimento do terceiro estágio da natureza humana, aquele que nos possibilita inclusive a amizade moral na qual floresce o amor recíproco lastreado pelo amor de si racional, como veremos mais adiante. Tratase da

3) disposição para a sua personalidade, como ser racional e, simultaneamente, susceptível de imputação

A disposição para a personalidade é a susceptibilidade da reverência pela lei moral como de um móbil, por si mesmo suficiente, do arbítrio. A susceptibilidade da mera reverência pela lei moral em nós seria o sentimento moral, que, no entanto, não constitui por si ainda um fim da disposição natural, mas só enquanto é móbil do arbítrio. Ora visto que tal é possível unicamente porque o livre arbítrio o admite na sua máxima, é propriedade de semelhante arbítrio o caráter bom; o qual, como em geral todo o caráter do livre arbítrio, é algo que unicamente se pode adquirir, mas para cuja possibilidade deve, no entanto, estar presente na nossa natureza uma disposição em que absolutamente nada de mau se pode enxertar. A mera ideia da lei moral, com o respeito dela inseparável, não pode em justiça denominar-se uma disposição para a personalidade; é a própria personalidade (a ideia da humanidade considerada de modo plenamente intelectual). Mas o fundamento subjetivo para admitirmos nas nossas máximas esta reverência como móbil parece ser um aditamento à personalidade e merecer, por isso, o nome de uma disposição em vista dela.

Ao observar as disposições da natureza humana como se em progresso contínuo, retomamos a lógica do pensamento de Kant cunhado em escritos como Religion e Paz Perpétua. Vemos assim que a disposição à personalidade (que Kant define como a ideia da humanidade considerada de modo plenamente intelectual) é um passo além, dado pela razão em relação à disposição à humanidade comparação do ser humano com o próximo. É a disposição que admite em sua máxima, através do livre arbítrio - livre de qualquer inclinação animal ou comparação racional de fenômenos -, a lei moral. Kant afirma que é propriedade do caráter (modo prático e coerente de pensar segundo máximas imutáveis ${ }^{103}$ ) o livre arbítrio bom, que admite a lei moral em sua máxima, algo que de fato se adquire, mas para o qual é necessária a pré-disposição livre de todo mau, que é o que ocorre justamente na disposição à personalidade. A receptividade, pelo respeito à lei moral em nós, é o sentimento moral, fim da 
disposição natural enquanto móbil do arbítrio e sentido, como vimos, pelo dano causado no amor de si pela razão pura prática. A ideia da lei moral e o respeito dela inseparável constituem a personalidade em si. A disposição à personalidade é fazer do respeito à lei nosso móbil e adotá-lo em nossa máxima. $\mathrm{E}$ como vimos anteriormente, tal sentimento moral ocorre justamente pela aniquilação, por parte da razão pura prática, do amor de si, tornando-o racional e, portanto, não apenas conforme à lei, mas também incentivador desta.

\title{
Da passagem do amor a si irracional à moralidade do amor de si racional
}

\begin{abstract}
Se considerarmos as três disposições mencionadas segundo as condições da sua possibilidade, descobrimos que a primeira não tem por raiz razão alguma, a segunda tem decerto por raiz a razão prática, mas ao serviço apenas de outros móbiles; só a terceira tem como raiz a razão por si mesma prática, a saber, a razão incondicionalmente legisladora: todas estas disposições no homem são não só (negativamente) boas (não são contrárias à lei moral), mas são igualmente disposições para 0 bem (fomentam o seu seguimento). ${ }^{104}$ São originárias, porque pertencem à possibilidade da natureza humana. $\mathrm{O}$ homem pode, sem dúvida, servir-se das duas primeiras contrariamente ao seu fim, mas a nenhuma delas pode extirpar. Por disposições de um ser entendemos tanto as partes constituintes para ele requeridas como ainda as formas da sua conexão para ser semelhante ser. São originárias, se pertencem necessariamente à possibilidade de um tal ser; e contingentes, se o ser for possível também sem elas. Importa ainda observar que aqui não se fala de nenhumas outras disposições exceto das que imediatamente se referem à faculdade de desejar e ao uso do arbítrio. ${ }^{105}$
\end{abstract}

Kant evidencia, nesta sequência final do trecho sobre as disposições, ao qual já me referi, a distribuição delas quanto ao uso da razão, evidenciando assim um natural progresso, coroando a disposição à personalidade como sendo a que instaura em nós a razão incondicionalmente legisladora ao nos elevarmos do medo animal e da insegurança racional da comparação fenomênica em sociedade e, em respeito, nos voltamos à lei moral (que nós mesmos nos damos face à ideia de humanidade considerada intelectualmente) - que é como Kant define a personalidade erigida sobre um caráter inteligível. A razão evolui com as suas disposições como não existentes na animalidade para a existência condicionada por inclinações e refém do jogo de comparações na humanidade para, por fim, libertar-se por si própria na ideia que concebe de si como legisladora absoluta e da qual somos exemplos práticos. Devemos ressaltar desta citação também que tais disposições: a) são originárias porque pertencem à possibilidade da natureza humana; b) são (negativamente) boas (sendo não contraditórias à lei moral) e também fomentam seu seguimento, sendo assim o

\footnotetext{
${ }^{104}$ Religion B18

105 Religion B19
} 
amor de si considerado disposição para o bem; c) pode-se fazer mau uso das disposições animal e humana, mas não da disposição à personalidade, porquanto nesta o respeito à lei the garante o uso em alinho ao seu fim e coerência com seus princípios. Nas disposições à animalidade e à humanidade a razão, ausente ou à serviço de outros móbiles, pode agir contrariamente ao seu fim, a saber, contra o bem. Kant usa para as duas primeiras disposições o termo Selbstliebe, traduzido como amor a si para a animalidade e amor de si na humanidade; já na disposição à personalidade deixa de usar o termo. A hipótese que levantamos é a de que, em se tratando de um progresso, a Selbstliebe passando de irracional para racional, ainda servindo às inclinações, se transforme finalmente em autoestima baseada no amor à honra, onde a razão é soberana na legislação do si mesmo. Afinal, toda ação humana deve ser exercida a partir do amor à honra ${ }^{106}$, chamada também de virtude ${ }^{107}$, nosso verdadeiro valor interno ${ }^{108}$. Isto, porque na disposição à humanidade Kant trata do valor ainda em relação na comparação com outros. Na disposição à personalidade, temos a ideia de humanidade servindo-nos de lastro para a ideia de lei moral, nosso valor absoluto, a dignidade humana. Ou seja, nossa personalidade é o respeito pela lei e a própria lei moral é nosso valor oriundo das ações que realizamos ${ }^{109}$. É

a ideia da personalidade que faz surgir em nós o respeito e põe-nos diante dos olhos a sublimidade da nossa natureza (segundo a sua determinação), e nos faz notar ao mesmo tempo, a falta de conformidade da nossa conduta relativamente a ela, aniquilando, assim, a nossa presunção, é uma ideia fácil de perceber para a razão humana, mesmo a mais comum. ${ }^{110}$

Kant ressalta aqui que a personalidade é nossa parcela sublime, enquanto que na $K p V$ atribui o sublime à nossa parcela suprassensível, o homo noumenon, a liberdade que temos de nos colocar fins e seguir a lei que estabelece nossos princípios. Eis o valor de nossa grandeza e nos confere o dinamismo de nosso progresso enquanto espécie, ideia presente em cada um de nós e que buscamos honrar através de nossas ações.

\footnotetext{
${ }^{106}$ Ethica - Teil B - p.206

107 TL420:26

${ }^{108}$ Ethica - Teil B - p.149

${ }^{109}$ Ethica - Teil B - p.174

${ }^{110}$ KpV 155
} 
Da segurança necessária para se acessar o sublime

Reforcemos aqui a necessidade de segurança que o humano tem para poder contemplar o sublime de sua personalidade, a sua liberdade e independência em relação a toda sua natureza sensível, a origem digna de sua nobre ascendência que repele todo parentesco com as inclinações, condição necessária para o ser humano se dar valor. Como vemos na Crítica da faculdade do juízo,

Quem teme a si não pode absolutamente julgar sobre o sublime da natureza, tampouco sobre o belo quem é tomado de inclinação e apetite. ${ }^{111}$

A condição para o sublime que eleva a fortaleza de nossa alma acima de seu nível médio é que nos encontremos em segurança ${ }^{112}$. Parece que enquanto o belo necessita do desinteresse, o sublime necessita do destemor, do sentimento de segurança, daquele que confia no poder de sua razão pura. E isto, por sua vez, parece ser determinado por uma disposição para a ação moral que honra a humanidade em nossa pessoa ${ }^{113}$ e que resulta e é resultante de uma estima correta de si mesmo, um ciclo de retroalimentação da autoestima moral baseada na justeza da ação.

De fato não se pode muito bem pensar um sentimento para com o sublime da natureza sem ligar a isso uma disposição do ânimo que é semelhante à disposição para o sentimento moral [...]. ${ }^{114}$

\section{Da função do sublime destemor no progresso ao amor de si racional}

O sublime não está contido na natureza, mas em nosso ânimo em função da consciência de que somos superiores à natureza, tanto à natureza interna e suas inclinações, quanto à natureza externa, na medida em que ela nos impacta. Conceber a ideia desse poder da natureza que desafia nossas forças e assim exercita nossa virtude de perseverar, de ajuizar sem medo esse poder e pensar

\footnotetext{
${ }^{111} \mathrm{KU} \mathrm{B} 103$

112 KU B104

${ }^{113}$ Ethica - Teil B - p.137

114 KU B116
} 
nossa destinação como sublime para além da natureza ${ }^{115}$, funda em nós o sentimento sublime que esteticamente é o entusiasmo ${ }^{116}$.

O sublime sempre tem de referir-se à maneira de pensar, isto é, a máximas para conseguir o domínio intelectual e das ideias da razão sobre a sensibilidade. ${ }^{17}$

Ao descobrirmo-nos independentes e acima da natureza, fundamos uma autoconservação de nossa espécie totalmente diversa da que pode ser atacada pela natureza, de tal modo que a humanidade em nós nunca seja rebaixada. Isso ressalta a força de nossa personalidade que assegura o valor da humanidade em nossos atos virtuosos. Tal autoestima não perde seu valor pelo fato de sentirmo-nos seguros para poder vivenciar a complacência entusiasmante ${ }^{118}$.

Pois que é isto que, mesmo para um selvagem, é um objeto da máxima admiração? Um homem que não se apavora, que não teme a si, portanto, que não cede ao perigo, mas ao mesmo tempo procede energicamente com inteira reflexão. Até no estado maximamente civilizado prevalece o apreço pelo guerreiro; só que ainda exige, além disso, que ele ao mesmo tempo comprove possuir todas as virtudes da paz, mansidão, compaixão e mesmo o devido cuidado por sua própria pessoa; justamente porque nisso é conhecida a invencibilidade de seu ânimo pelo perigo. ${ }^{119}$

Se entendermos nesta leitura que a invencibilidade do ânimo pelo perigo se encontra justamente no devido cuidado com sua própria pessoa, podemos atribuir a isto o conceito de amor de si racional, uma vez que este zela por sua existência nos justos limites morais e conformes à lei. Se adicionarmos a isto a combatividade e as virtudes da paz, ressaltando-se a compaixão, resultando em uma imagem de guerreiro da paz, podemos sem medo de errar pensar na figura de Cristo, que com seu Evangelho demonstrou a necessidade de submeter toda boa conduta do homem à disciplina de um dever posto ante os seus olhos. Isto impede que se caia na armadilha de imaginárias perfeições morais, impondo à presunção do amor-próprio as limitações do desconhecimento de si mesmo. ${ }^{120}$

\footnotetext{
${ }^{115} \mathrm{KU} \mathrm{B} 109$

${ }^{116} \mathrm{KU} \mathrm{B} 121$

117 KU B124

${ }^{118} \mathrm{KU} \mathrm{B} 105$

${ }^{119} \mathrm{KU}$ B106

$120 \mathrm{KpV} 154-155$
} 
Da relação do dever com o sublime

Mais uma vez, fica clara a necessidade da pureza do princípio moral, realizado na pureza da representação das máximas e no esmero da escolha dos exemplos, para impor à presunção [Eigendünkel], bem como ao amor-próprio [Eigenliebe], em suma, ao amor de si mesmo [Selbstliebe], o limite imposto pela humanidade, ou seja, o limite de seu autoconhecimento. O que indica ser imperativo a busca pelo autoconhecimento, na ampliação do conhecimento de si mesmo, no mínimo do que se deve fazer.

Dever! - Nome sublime e grande, tu que não encerras nada amável que leve consigo alguma insinuante lisonja, mas que pedes submissão, sem contudo ameaçar com algo que desperte natural aversão no ânimo, atemorizando-o para mover a vontade, tu que só exiges uma lei que por si mesmo encontra acesso ao ânimo e que, não obstante, conquista, ainda mesmo contra a nossa vontade, veneração por si mesma (embora nem sempre a observemos); tu, ante quem emudecem todas as inclinações, mesmo quando agem secretamente contra ti qual é a origem digna de ti? Onde se encontra a razão de tua nobre ascendência, que repele orgulhosamente todo o parentesco com as inclinações, essa raiz da qual é condição necessária que proceda aquele valor que só os homens podem dar a si mesmos? ${ }^{121}$

A indagação que fica é a que concerne à possibilidade de se amar justamente o valor que se dá a si mesmo a partir de sua nobre ascendência noumênica. Devemos nos amar e às nossas ações enquanto exemplos de moralidade, para assim cuidar destas e realiza-las com satisfação. Devemos amar nossa personalidade por assim amar e livremente adotar a ideia de humanidade presente em nós, concebendo a possibilidade de amarmos universalmente a humanidade, o que, como veremos adiante, é de suma importância para nossa empreitada.

Não pode ser nada menos do que o que eleva o homem acima de si mesmo (como uma parte do mundo dos sentidos), o que o conjuga com uma ordem de coisas, que só o entendimento pode pensar e que, ao mesmo tempo, tem debaixo de si todo o mundo dos sentidos e com ele a existência empiricamente determinável do homem no tempo e em todos os fins (conformando-se unicamente a leis práticas incondicionadas, como seja, entre elas, a moral). Não é nada mais do que a personalidade, isto é, a liberdade e independência do mecanismo de toda a natureza, considerada essa liberdade, apesar de tudo, ao mesmo tempo como uma faculdade de um ser que está submetido a leis puras práticas correlatas, isto é, facultadas pela sua própria razão; por conseguinte, a pessoa, como pertencente ao mundo sensível, está sujeita a sua própria personalidade, ao mesmo tempo que pertence ao mundo inteligível. Não é portanto de admirar que o homem, como pertencente a ambos os mundos, tenha que considerar o seu próprio ser em relação com a sua segunda e mais elevada

${ }^{121} \mathrm{KpV} 154$ 
determinação, devendo, também, considerar com o máximo respeito as leis dessa determinação. ${ }^{122}$

Amar nossa personalidade é amar a liberdade que nos confere todo valor, é colocar nossa autoestima além do sensível. A autoestima moral ocorre em dois sentidos: em termos absolutos, por ter a liberdade em si enquanto homo noumenon, e em termos relativos, pelo grau em que superamos nossas inclinações enquanto homo phaenomenon. Kant, mais uma vez, recorre à unidade humana $^{123}$, pertencente tanto ao mundo sensível enquanto pessoa, e pertencente ao mundo inteligível enquanto personalidade. Devemos considerar nosso próprio ser em relação a nossa mais elevada determinação e às leis dela oriunda. Tudo indica que somos nós, em função de nossa razão prática, nossa vontade que quer se (a)firmar, que determinamos nossos limites e, assim, nossos caminhos.

Se introduzíssemos em nossa ação algo de lisonjeiro acerca da ideia do mérito, então o móvel ficaria confundido com o amor próprio; há portanto um apoio por parte da sensibilidade. Por outro lado, tudo subordinar à ideia da santidade do dever e nutrir a consciência de que se pode por reconhecê-lo a nossa própria razão como mandato seu, proclamando que se deve fazê-lo, significaria elevarse, por assim dizer, muito acima do mundo sensível. É nessa consciência da lei que se situa, inseparavelmente da mesma, o móvel de uma faculdade que domina a sensibilidade, embora nem sempre com o efeito desejado; mas a realização exata desse efeito nos é dado esperar quando, mediante frequentes ensaios e exercícios de seu uso, inicialmente escassos, faculta-nos a esperança de sua realização, produzindo pouco a pouco em nós um interesse maior, embora puramente moral. ${ }^{124}$

Kant reforça a importância do desinteresse no efeito da ação moral, mas não na determinação da ação. $O$ interesse pelo fim deixa de lado o valor moral da ação, pois toda expectativa de mérito levaria o móbil a se confundir com o amor-próprio. O interesse pela lei da razão remete à questão supracitada do belo e ao conceito de desinteresse ligado ao belo: agir pela necessidade da ação, sem interesse direto no ganho, mas na pureza da ação, independente da inclinação ou apetite. O belo que se pauta pela forma da lei: devemos, portanto, aspirar que nossa ação se torne exemplo desta. Mais uma vez, Kant antecipa a noção de numero idem e a nossa dupla personalidade: homo noumenon, que é a consciência da lei e homo phaenomenon, que é o fenômeno a ser dominado através do interesse maior, puramente moral. $O$ interesse maior de nossa

\footnotetext{
$122 \mathrm{KpV} 155$

${ }^{123}$ Numero idem é o termo em latim que Kant utiliza para esclarecer que - apesar da dupla disposição da personalidade retratada como noumenon-phaenomenon, juiz-réu e professor-aluno - trata-se sempre da mesma pessoa

${ }^{124} \mathrm{KpV} 283$
} 
personalidade noumênica se apresenta como respeito e se sente no ânimo como o entusiasmo proveniente do sentimento moral ao se contemplar a grandeza da humanidade que nos habita e nos conduz a um novo horizonte que confirma nossa disposição para o bem: do amor a si progride mecanicamente ao amor de si, que, pela via racional, evolui à autoestima que se configura na valorização da humanidade em cada ação. Neste contexto, a máxima do amor de si mesmo, a prudência, é determinante para assegurar nossa segurança física do homo phaenomenon, fundamental para a contemplação do sublime de nossa natureza moral do homo noumenon como pretendemos ter comprovado. $E$ contemplar a natureza moral somente é possível após termos, primeiro assegurado nossa segurança para, em seguida, por respeito à lei, ter concebido o amor de si racional. Logicamente, conceber a lei é o princípio de toda ação moral, mas para tal é necessário a garantia da existência, senão não há espaço para intenções morais, apenas reflexos e instintos de sobrevivência no contexto da disposição para o bem do amor a si. Todavia, como atuamos na liberdade exigida pela lei que nos impomos, já não há necessidade de medo, já que a lei nos inclui e assegura o necessário enquanto fim. Eis o marco da consciência que viabiliza a união da busca pela felicidade por parte do homo phaenomenon e da atuação virtuosa que emana do homo noumenon. Se não há mais preocupação com a sobrevivência, resta apenas a necessidade de valorização da vivência, cessando o conflito de nossa natureza dual e focando no progresso contínuo: o valor moral se estabelece na obediência à lei que garante não somente a sobrevivência, mas a vivência.

Com efeito, se para determinar o arbítrio a ações conformes à lei, são necessários outros móbiles diferentes da própria lei (e.g. ânsia de honras, amor de si em geral, ou inclusive um instinto benévolo, como é a compaixão), então é simplesmente casual que eles concordem com a lei; pois poderiam igualmente impelir à sua transgressão. A máxima, segundo cuja bondade se deve apreciar todo o valor moral da pessoa, é, no entanto, contrária à lei, e o homem, embora faça só ações boas, é, contudo, mau. ${ }^{125}$

Kant reforça a importância do princípio de toda ação moral ser a lei pura da razão e, por mais que se aja em conformidade com a lei, o valor da ação não pode ser considerado moral, sendo mau quem age apenas por conformidade. A bondade está então diretamente ligada ao interesse na lei da razão que garante a pureza dos princípios.

${ }^{125}$ Religion B24 


\title{
Da compreensão da proposta
}

Ressaltemos da citação acima, a título de clareza de nossa proposta, a casualidade de concordância segundo a qual concordam à lei a ânsia de honras, o amor de si geral e inclusive o instinto benévolo. Faz-se necessário reforçar que não tratamos em nossa proposta da ânsia de honras [Ehrbegierde], mas do amor à honra. Tampouco do amor de si em geral, mas especificamente do amor de si racional, cuja gênese moral já explicitamos através da humilhação da consciência de nosso valor, que só se sustenta se baseado na moral. Consciência que se exalta justamente por pensar segundo as três máximas do senso comum cuja segunda máxima, a de pensar no lugar do outro em alinho com o pensar consigo próprio e em concordância consigo mesmo e com a lei, não só indicam a adoção consciente da vontade alheia sob sua máxima, como a necessidade de subordinar sua máxima à lei. Isto nos possibilita abrir mão do instinto benévolo, praticando assim o que podemos chamar de compaixão racional ou ainda inteligência emocional racional, estando assim livres das oscilações das inclinações dos instintos. Extrairemos da citação a seguir alguns entendimentos:

\begin{abstract}
O homem (inclusive o pior), seja em que máximas for, não renuncia à lei moral, por assim dizer, rebelando-se (com recusa da obediência). Pelo contrário, a lei moral impõe-se-lhe irresistivelmente por força da sua disposição moral; e, se nenhum outro móbil atuasse em sentido contrário, ele admiti-la-ia na sua máxima suprema como motivo determinante suficiente do arbítrio, i.e., seria moralmente bom. Mas ele depende também, em virtude da sua disposição natural igualmente inocente, de móbiles da sensibilidade e acolhe-os outrossim na sua máxima (de acordo com o princípio subjetivo do amor de si). ${ }^{126}$
\end{abstract}

a) móbiles da sensibilidade são acolhidos de acordo com o princípio subjetivo do amor de si; o que torna o amor de si o princípio subjetivo organizador das inclinações. Podemos imaginar que, ao invés de superar uma a uma as inclinações, basta racionalizar o princípio subjetivo para subjugar todas as inclinações de uma vez à lei.

Se, porém, admitisse tais móbiles na sua máxima como suficientes por si sós para a determinação do arbítrio, sem se virar para a lei moral (que, no entanto, em si tem), então seria moralmente mau. Ora uma vez que ele acolhe de modo natural ambas as coisas na sua máxima, uma vez que acharia também cada uma por si, se estivesse só, suficiente para a determinação da vontade, assim, se a diferença das máximas dependesse simplesmente da diferença dos motivos (da matéria das máximas), a saber, de se é a lei, ou o impulso dos sentidos, o que proporciona tal móbil, então o homem seria ao mesmo tempo moralmente

${ }^{126}$ Religion B33-B34 
bom e moralmente mau - o que (segundo a introdução) se contradiz. Portanto, a diferença de se o homem é bom ou mau deve residir, não na diferença dos móbiles, que ele acolhe na sua máxima (não na sua matéria), mas na subordinação (forma da máxima): de qual dos dois (móbiles) ele transforma em condição do outro. ${ }^{127}$

b) a bondade/maldade não está na materialidade de seus móbiles, mas na hierarquia de suas máximas; o que reforça a proposta de leitura do item a) de se focar na racionalização do amor de si como meio de garantir a obediência das inclinações à lei.

Por conseguinte, o homem (inclusive o melhor) só é mau em virtude de inverter a ordem moral dos motivos, ao perfilhá-los nas suas máximas: acolhe decerto nelas a lei moral juntamente com a do amor de si; porém, em virtude de perceber que uma não pode subsistir ao lado da outra, mas uma deve estar subordinada à outra como à sua condição suprema, o homem faz dos móbiles do amor de si e das inclinações deste a condição do seguimento da lei moral, quando, pelo contrário, é a última que, enquanto condição suprema da satisfação do primeiro, se deveria admitir como motivo único na máxima universal do arbítrio. ${ }^{128}$

c) não se pode fazer concessões, não se pode estabelecer condições para se seguir a lei moral que deve, por sua vez, ser a condição suprema para a satisfação do amor de si e suas inclinações, sendo a lei moral o único motivo na máxima universal do arbítrio. Isto seria um bom argumento para a conversão dos espíritos não educados moralmente. Kant indica assim que há uma plausibilidade em nossa proposta, ao aceitar o argumento de coexistência do benefício próprio quando em concordância à lei. $E$ mais, que é necessário demonstrar àqueles não educados moralmente que a lei também os inclui e beneficia, bastando para tal compreenderem sua viabilidade dentro dos caminhos propostos pela razão, uma vez que devem ser possíveis, porque de outra maneira teriam sido aniquilados.

Na verdade, não se pode negar que, para trazer para o caminho do bem moral um espírito ainda inculto ou degradado, seja necessário prepara-lo, atraindo-o com a perspectiva da vantagem pessoal ou intimidando-o mediante a ameaça de um dano; mas apenas esse mecanismo, esse recurso, tenha produzido algum efeito, há necessidade de mostrar à alma o puro princípio moral de determinação, que não somente por ser o único que pode fundar um caráter (modo prático e coerente de pensar segundo máximas imutáveis), mas ainda porque ensina o homem a sentir a sua própria dignidade, dá à alma uma força que ele mesmo não esperava, a fim de desfazer-se de toda dependência sensível, enquanto ela quer ser predominante e encontrar na independência de

\footnotetext{
${ }^{127}$ Religion B33-B34

128 Religion B33-B34
} 
sua natureza inteligível e na grandeza de alma, a que é destinada, uma grande compensação pelo sacrifício. ${ }^{129}$

O que vemos até aqui, portanto, é que o problema não é o amor de si em si mesmo, pois ele pode ser visto como sendo positivo até por trazer consigo uma disposição para o bem e ser o princípio subjetivo que converge as inclinações à felicidade. O que tem de ser afastado é o mau uso que se faz do amor de si por falta de esclarecimento do correto processo de hierarquização ao tornar o amor de si princípio legislador. Pois é a correta hierarquização das máximas sob o princípio da lei que garante a supremacia da lei moral. Para sairse do conflito que o amor de si traz consigo é necessário, em função do papel da razão pura prática, tornar-se soberano de si mesmo, senhor de sua vontade. Sem esse esforço, poderíamos dizer que tanto o amor de si, quanto a razão, sofrem da preguiça e covardia ${ }^{130}$, oriundos do medo de se pensar por si mesmo, e, portanto, sucumbem ao vício da alienação das máximas em relação às inclinações. O que a citação a seguir comprova:

\begin{abstract}
Nesta inversão dos motivos, graças à sua máxima, contra a ordem moral, as ações podem, apesar de tudo, ocorrer de modo tão conforme a lei como se tivessem promanado de princípios legítimos: quando a razão se serve da unidade das máximas em geral, que é peculiar à lei moral, simplesmente para introduzir nos móbiles da inclinação, sob o nome de felicidade, uma unidade das máximas que, aliás, não lhes pode caber (por exemplo, que a veracidade, se se adotar como princípio, nos dispensa da inquietude de manter a consonância das nossas mentiras e de não nos enredarmos a nós mesmos nas sinuosidades das mesmas), já que então o caráter empírico é bom, mas o inteligível é, porém, sempre mau. ${ }^{13}$
\end{abstract}

Parece que só nos resta conclamar o amor à consciência do si mesmo, racionalizando-se o que se deve e, portanto, como se deve hierarquizar suas máximas. Aude sapere, Amor!

\footnotetext{
${ }^{129} \mathrm{KpV} 271$

${ }^{130} \mathrm{O}$ que é esclarecimento? p.5

131 Religion B35
} 


\section{4}

\section{O Amor de si racional enquanto amor à lei - do progresso moral de si ao conceito de humanidade}

Até aqui falamos ao longo desta dissertação da máxima do amor-próprio (prudência), dos princípios do amor-próprio (satisfação das inclinações), do sistema do amor-próprio (felicidade pessoal), mas ainda não abordamos os deveres do amor de si mesmo, obrigando-nos a pensar em nós mesmos, bem como em todo ser humano, como um fim. O que claramente parece ser o dever do amor de si mesmo que se tornou racional, pois nesse caso, se está sob um dever, está nos justos limites da lei. Neste terceiro capítulo, veremos se podemos confirmar o amor de si racional como amor à lei e se, na prática, isto pode ser compreendido como amor recíproco que sustenta uma humanidade fraterna em constante progresso moral ${ }^{132}$.

A benevolência pode ser ilimitada, pois neste caso não se exige que algo seja feito. Contudo, com relação à beneficência, sobretudo se deve ocorrer não por afeição (amor) pelos outros, mas antes por dever, com sacrifício e mortificação de várias concupiscências, a questão é mais difícil. Que essa beneficência seja um dever resulta do seguinte: uma vez que nosso amor de nós mesmos (Selbstliebe) não pode ser separado da carência de também sermos amados por outros (em casos de necessidade, ajudados), tomamos nós mesmos como fim para outros, e como esta máxima não pode obrigar de outra maneira senão meramente por meio de sua qualificação para uma lei universal, consequentemente, por meio de uma vontade de propor também para nós os outros como fins, a felicidade alheia é um fim que é ao mesmo tempo dever. ${ }^{133}$

Do amor de si ao amor ao próximo: o amor recíproco à moralidade

Kant atrela o amor-próprio à nossa necessidade de sermos amados e, por obrigação lógica da universalidade, ao fazermos de nós fim para outros, devemos fazer dos outros fins para nós, sendo assim a felicidade alheia um fim que ao mesmo tempo é dever. Há aqui então uma clara correspondência entre o amor de si e o amor ao próximo, sendo o primeiro lastro para o segundo e este, como veremos, regulador do primeiro. Não à toa, o texto da Doutrina da virtude, mais que uma doutrina do dever em geral, deve ser compreendido como doutrina dos fins, já que a virtude é a força moral que busca realizar-se.

\footnotetext{
${ }^{132}$ Ao qual podemos atribuir os conceitos de sumo bem e paz perpétua, mas que, por motivos de tempo apenas indicamos sem poder nos debruçar sobre uma explicação mais detalhada. ${ }^{133} \mathrm{TL} 393$
} 
[...] no tocante ao elemento material, ela [doutrina da virtude] tem de ser estabelecida não apenas como doutrina do dever em geral, mas também como doutrina dos fins; de modo que o ser humano esteja obrigado a pensar tanto em si mesmo quanto em todo outro ser humano como fim seu (que se costuma denominar deveres de amor de si mesmo [Selbstliebe] e de amor ao próximo [Nächstenliebe]), expressões que são aqui tomadas em um sentido impróprio; pois não pode haver nenhum dever direto para amar, mas antes para realizar ações por meio das quais o ser humano propõe a si mesmo e aos outros como fim. $^{134}$

Ou seja, não se impõe o amor, antes se dispõe das condições para se amar, agindo-se de maneira a propor a si mesmo e aos outros como fins. Em outras palavras de Kant em sua conceituação de amor em O Fim de todas as coisas $^{135}$ : o amor como o livre acolhimento da vontade alheia sob nossas máximas. Sem esquecermos de subordinar nossa máxima à lei, conforme nos lembra esta passagem da Doutrina da virtude:

No que concerne, entretanto, ao dever do homem para consigo mesmo unicamente enquanto ser moral (sem considerar sua animalidade), ele consiste no elemento formal da concordância das máximas de sua vontade com a dignidade da humanidade em sua pessoa; [...] $]^{136}$

É justamente a subordinação consciente de nossas máximas à lei, o que nos confere valor moral. A dignidade da humanidade em nós é precisamente a representação da lei por nossa personalidade, a terceira disposição originária para o bem, com a qual as máximas de nossa vontade devem concordar.

\section{Do amor de si racional como lastro da virtude}

No que concerne, entretanto, ao dever do homem para consigo mesmo unicamente enquanto ser moral [...] consiste, portanto, na proibição de privar-se do privilégio de um ser moral, a saber, agir segundo princípios, isto é, na proibição de privar-se da liberdade interna e de transformar-se, assim, em um jogo de meras inclinações, portanto, em uma coisa. [...] A virtude [...] poderia ser denominada amor à honra (honestas interna, iustum sui aestimium), um modo de pensar diametralmente oposto à ambição (ambitio) [...]. ${ }^{137}$

Podemos então relacionar o dever do amor de si racional, que é ser fim para si mesmo, com o dever do homem para consigo mesmo unicamente enquanto ser moral, uma vez que o fim deste é a liberdade que o obriga a honrar o privilégio de um ser moral de justamente colocar-se fins. E qual o maior fim do

\footnotetext{
${ }^{134} \mathrm{TL} 410$

${ }^{135} \mathrm{O}$ fim de todas as coisas - p.13 - 8:338

${ }^{136}$ TL 420

137 TL 420
} 
que o ser fim para si mesmo? Ou seja, a liberdade nos obriga ao dever do amor de si racional. Ao ter como dever ser fim para si mesmo, o amor de si racional abre o caminho para o dever do homem moral qualificar seu fim, colocando-se fins pelo princípio da liberdade assegurado pelo dever do amor de si racional. Kant denomina a virtude, nossa força moral, também de amor à honra, cujo termo latim significa honestidade interna, em função de uma estima justa de si, o que diz muito sobre a proposta que faz: a força moral (virtude) é uma honestidade interna e tanto gera como se baseia em uma estima justa de si. Isto motiva a honra a qual aspiramos realizar com satisfação através da ação moral, o único meio de sermos dignos de valor moral e representarmos a dignidade humana em ato.

A máxima da benevolência (o amor prático aos homens) é um dever de todos os homens, considerem-se estes dignos de amor ou não, segundo a lei ética da perfeição: ame o próximo como a você mesmo. ${ }^{138}$

Parece que a medida de amor ao próximo é a medida do amor de si racional, dentro dos limites da lei ética da perfeição, ou seja, observando-se a si mesmo sob o mais alto e elevado grau para a partir disto cumprir com satisfação os deveres para com o próximo (amor prático) em uma relação lastreada pelo que há de mais elevado em si.

Pois toda relação prático-moral entre homens é uma relação dos mesmos na representação da razão pura, isto é, das ações livres segundo máximas que se qualificam a uma legislação universal e que, portanto, não podem ser egoístas (ex solipsismo prodeuntes). ${ }^{139}$

Pode-se compreender melhor esta passagem sob a luz do conceito de "eu verdadeiro", homo noumenon ${ }^{140}$. O homo noumenon é a parte de nossa personalidade que se dá as leis e, que, portanto, na relação com o próximo, lida com igualdade. $O$ que remete à disposição originária para o bem enquanto personalidade. Baseado na comunicabilidade da razão, o homo noumenon é livre do egoísmo prático-empírico do homo phaenomenon (nosso eu patologicamente determinado e que assim age motivado pelo medo e insegurança) o que remete à disposição originária para o bem enquanto humanidade. Ressaltamos também a elevação da comparação, de fenomênica e 
refém da insegurança psicossocial na comparação empírica entre pessoas, para a comparação do indivíduo com a lei. O que reforça a noção de passagem à moralidade a partir da evolução do amor a si ao amor de si racional. Isto ocorre quando nos centramos e, seguros em relação às nossas necessidades básicas de sobrevivência, agimos a partir de nossa personalidade podendo então agregar valor na interação com o mundo.

\title{
Da ampliação do amor à universalidade pela razão
}

\begin{abstract}
Quero que outros tenham benevolência (benevolentiam) por mim; portanto, devo também ser benevolente com todos os outros. Mas, posto que todos os outros exceto eu não são todos e, assim, a máxima não conteria em si a universalidade de uma lei, universalidade essa que, entretanto, é necessária para a obrigação, então, no comando da razão prática pura, a lei do dever de benevolência compreenderá a mim como seu objeto; não como se, por isso, eu estivesse obrigado a amar a mim mesmo (pois isso ocorre sem este dever, inevitavelmente, e para tanto não existe obrigação), mas sim porque a razão legisladora, não o homem, em sua ideia de humanidade em geral, inclui toda espécie (portanto, também a mim), isto é, porque a razão legisladora, segundo o princípio da igualdade, inclui a mim, enquanto universalmente legislador, bem como todos próximos a mim, no dever de benevolência recíproca, o que permite você querer bem a você mesmo, sob a condição de que também queira bem a todos, pois apenas assim sua máxima (da beneficência) se qualifica a uma legislação universal, como aquilo sobre o que se fundam todos os outros deveres. ${ }^{141}$
\end{abstract}

É permitido querer o bem para si mesmo, amar-se, se isto não excluir o outro de seu bem querer, pois ao amar a si e ao outro como a si mesmo, qualifica-se sua máxima de benevolência a uma legislação universal como aquilo sobre o que se fundam todos os deveres. Aquele que transgride a humanidade em si não é capaz de honrar a humanidade no outro, sendo que os deveres para consigo mesmo são fundamentos para o dever para com os outros. Por fim, como posso amar o outro, no amor prático que é realizar com satisfação os deveres para com o outro, se não sou capaz de me amar? E assim, sem amor, como tornar necessário aquilo que a razão prescreveu mediante a lei ${ }^{142}$ ?

No amor universal aos homens, a benevolência é, de fato, a maior quanto à extensão, mas a menor quanto ao grau, e quando digo que participo do bemestar deste homem apenas segundo o amor universal aos homens, o interesse que tomo aqui é o menor que pode haver. Apenas não sou indiferente em relação a este homem. Entretanto, um está mais próximo de mim que o outro e, na benevolência, sou o mais próximo de mim mesmo. Mas como isto concorda com a fórmula: ame a seu próximo (seus semelhantes) como a você mesmo? Se um me é mais próximo (no dever de benevolência) do que o outro, se, portanto,

\footnotetext{
${ }^{141}$ TL 451

${ }^{142} \mathrm{O}$ fim de todas as coisas - p.13
} 
estou obrigado a uma maior beneficência perante um do que perante outro, mas, se obviamente estou mais próximo de mim mesmo (inclusive segundo o dever) do que de todos os outros, então, ao que parece, não posso afirmar, sem me contradizer, que devo amar a todos os homens como a mim mesmo; pois o critério do amor de si [Selbstliebe] mesmo não daria lugar a nenhuma distinção de grau. Vê-se logo que aqui não se pensa meramente na benevolência do desejo, que, de fato, é uma mera complacência no bem-estar de todos outros, sem que se tenha de contribuir para isso (cada um por si; Deus por todos), mas sim em uma benevolência ativa, prática, a saber, propor-me como fim o bem estar e a saúde do outro (a beneficência). Pois, no desejar, posso querer bem a todos igualmente, mas, no fazer, o grau pode ser muito variado, segundo a diversidade daqueles a quem se ama (dentre os quais um me é mais próximo do que outro), sem violar a universalidade da máxima. ${ }^{143}$

Mais que definir melhor a relação entre benevolência e beneficência, que viabiliza a não contradição da máxima em sua universalidade diante da diversidade de proximidades, vale ressaltar o que Kant pontua quanto ao critério do amor de si: a medida do amor de si não dá lugar a nenhuma distinção de grau. Que o aparente paradoxo se resolve na distinção entre benevolência e beneficência é algo que não é nosso objetivo aqui esmiuçar. O que nos importa muito mais é entender que, uma vez que o amor de si tenha se tornado amor de si racional ao sofrer o dano provocado pela razão pura prática e está em conformidade com a lei a partir dos princípios morais, pode se tornar medida para a igualdade nas relações e aliado da ação moral na medida de sua conformidade com a lei e seu interesse moral. Quando o amor de si racional atua como aliado da ação moral, se torna motivo de valorização da autoestima moral a partir da dignidade que tais ações morais nos conferem.

Benevolência é a satisfação na felicidade (no bem-estar) do outro; mas a beneficência é a máxima de propor-se isso como fim, e o dever que the corresponde é a necessitação do sujeito, exercida pela razão, a admitir essa máxima como lei universal. ${ }^{144}$

A benevolência repousa sobre a dignidade intrínseca ao valor humano enquanto sujeito moral. Já a beneficência se pauta pela ação relativa à virtude e se relativiza pela proximidade, que afirma ser um dever de todo homem ajudar o próximo. Tratamos aqui do progresso moral movido pela virtude, cujo lastro é a inabalável humanidade intrínseca a cada sujeito moral, que age por amor à lei e se confunde com o amor de si racional. Apesar de termos esta infinita grandeza em nós, turvamos nossa visão destes valores elevados por causa de nossa presunção. E na medida em que aniquilamos virtuosamente a presunção, damos espaço para o valor que emerge da ação moral em um constante progresso que

143 TL 452
144 TL 452 
pode ser medido pelo grau de evolução do amor de si: do puramente animal amor a si ao amor de si racional que cultiva a autoestima lastreada no sentimento moral de respeito à lei. Em suma, admitir a máxima da beneficência, de se colocar a felicidade alheia como fim, como lei universal, é o mais alto grau do dever de amor para com o próximo e do dever de amor para consigo. Dever este ao qual nos obriga a liberdade e ao qual nos conduz a virtude.

\section{Do caminho entre o respeito e o amor}

Ser beneficente, isto é, ajudar outros homens em necessidade com vistas à sua felicidade, é um dever de todo homem. Pois todo homem que se encontra em necessidade deseja ser ajudado por outros homens. Mas se ele manifestasse em voz alta sua máxima de não querer, por seu turno, prestar assistência aos outros em suas necessidades, isto é, convertesse a máxima em uma lei permissiva universal, então, qualquer outro lhe negaria igualmente assistência quando ele se encontrasse em necessidade, ou ao menos estaria autorizado a negá-la. Portanto, a máxima do interesse próprio contradiria a si mesma se fosse convertida em lei universal, isto é, ela é contrária ao dever, por consequência, a máxima do interesse comum relativo à beneficência perante os necessitados é um dever universal dos homens, e precisamente porque eles têm de ser considerados semelhantes, isto é, seres racionais carentes, unidos pela natureza em um habitat para auxílio mútuo. ${ }^{145}$

Kant reforça a contradição em que se encontra o interesse próprio ao buscar a universalidade, evidenciando sua contradição em relação ao dever e utiliza como lógica a inconsistência e a incoerência do querer para si algo que não quer para o semelhante, o que torna a máxima contrária ao dever. Todavia, não há objeção em ter a máxima do interesse comum relativo à beneficência como dever e utilizar como máxima subordinada, a máxima do interesse próprio, uma vez que na universalidade existente no dever eu também esteja incluído e deva agir para que este se realize. Registra-se que Kant mesmo afirma que amor e respeito são os sentimentos que acompanham o cumprimento desses deveres $^{146}$. Enquanto, na fase da animalidade, o amor provoca a aproximação para constituir a sociedade, o respeito garante o necessário distanciamento para a edificação da humanidade. É a personalidade, a ideia meramente intelectual de humanidade em nós, que regula o distanciamento e a proximidade dos indivíduos de acordo com os preceitos da lei moral, cultivando assim o florescimento das disposições para o bem.

O fundamento da vontade pode ser remetido, em vistas do amor, ao fim em relações morais de seres racionais que contêm um princípio de concordância

\footnotetext{
${ }^{145}$ TL 453

146 TL 448
} 
da vontade de um com outro, balizado pela articulação das forças do amor e do respeito $^{147}$. Quanto a sermos unidos pela natureza em um habitat para auxílio mútuo, isto remete à disposição à animalidade, nosso impulso à sociedade, mas também à comunicabilidade da razão que perfaz nossa humanidade e configura nossa personalidade. $\mathrm{O}$ amor, que começa por si e serve de medida ao próximo ao adotar a vontade - e necessidade - deste sob sua própria máxima, deve subordinar-se à lei autolegislada a partir do alto da liberdade que tanto estimamos e que nos obriga justamente ao dever do amor de si racional de ser fim para si mesmo e ter o outro como fim em si.

\section{Do primeiro comando do amor de si racional - ama a lei como a si mesmo}

Este comando (o primeiro comando de todos os deveres para consigo mesmo) é: conheça (examine, sonde) a si mesmo não segundo sua perfeição física (aptidão ou inaptidão para quaisquer fins, arbitrários ou mesmo ordenados), mas antes segundo a perfeição moral em relação ao seu dever; conheça seu coração - se ele é bom ou mau, se a fonte de suas ações é pura ou impura, e o que pode ser atribuído ao próprio homem ou como originariamente pertencente à sua substância ou como derivado (adquirido ou contraído) e o que pode pertencer ao estado moral. ${ }^{148}$

Se o dever do homem para consigo mesmo enquanto ser moral é agir segundo princípios e se o primeiro comando é conhecer seu coração, infere-se que se garante a liberdade interna (que obriga ao amor de si racional, o ser fim para si mesmo) ao conhecer-se seu coração. Ou seja, quanto mais se conhece seu coração, o princípio subjetivo de nossas máximas, maior nossa liberdade interna e, portanto, maior nossa moralidade e obrigação de cumprir com o dever do amor de si racional de sermos fins para nós mesmos. Isso que leva o coração a ser elemento-chave de nosso esclarecimento e fundamental para o exercício da razão e execução da ação moral. Como Kant já havia indicado na Religion, é no coração humano que as prescrições do dever foram originariamente escritas pela razão ${ }^{149}$ e que

O autoconhecimento moral que exige penetrar nas profundezas do coração mais difíceis de sondar (o abismo) é o início de toda sabedoria humana. Com efeito, esta sabedoria, que consiste na concordância da vontade de um ser com um fim terminal, demanda do homem, em primeiro lugar, a remoção dos obstáculos internos (de uma vontade má aninhada nele) e, em seguida, o desenvolvimento

\footnotetext{
${ }^{147} \mathrm{TL} 488$

${ }^{148}$ TL 441

149 Religion B116
} 
da disposição originária inalienável de uma boa vontade (somente a descida aos infernos do autoconhecimento constrói o caminho da glorificação). ${ }^{150}$

Segundo Kant é possível à razão sondar seus princípios e esclarecer, por meio da reflexão os motivos das ações humanas. Através da remoção dos obstáculos internos fomentamos a boa vontade em um processo como o já visto na Critica da razão prática ${ }^{151}$, gerando assim as condições para o sentimento moral, a capacidade de tomar interesse pela lei a partir da aniquilação da presunção e do cultivo do amor de si racional. Tal consciência de livre submissão da vontade à lei autoexercida a partir de uma autolegislação moral gera um efeito subjetivo de elevação do sentimento: um sublime sentimento de respeito pela grandeza humana de não apenas se colocar fins morais, mas também encontrar os meios possíveis para realiza-los. Tal movimento interno pode gerar, se não estiver solidamente amparado no respeito à lei, a inversão da hierarquia e consequente subordinação das máximas ao amor-próprio, corrompendo radicalmente toda boa vontade. Essa inversão condiciona a obediência da lei à satisfação pessoal; mas é necessário cultivar o desinteresse pelas inclinações para poder utilizar as máximas do amor-próprio como apoio à moral na qual felicidade do ser humano também está contida. Caso contrário, pode-se cair na armadilha da presunção, já indicada anteriormente neste trabalho. O caminho rumo à moralidade passa pelo mergulho da razão nas profundezas do coração e consequente esclarecimento de nossos princípios subjetivos.

Este autoconhecimento moral banirá primeiramente o desprezo fanático de si mesmo como homem em geral (o desprezo de toda sua espécie); pois este contradiz a si mesmo. Somente graças à nobre disposição para o bem, presente em nós, que torna o homem digno de respeito, pode ocorrer que ele considere desprezível o homem que age contra tal disposição (considere ele próprio desprezível, mas não a humanidade nele). Mas, em seguida, este autoconhecimento também se contrapõe à autoestima fundada no amor próprio de considerar como provas de um bom coração meros desejos que, mesmo ocorrendo com muito mais ardor, são e permanecem destituídos de efeito [...]. Imparcialidade no julgamento de nós mesmos em comparação com a lei e sinceridade na autoconfissão de seu valor ou não valor moral interno são deveres para consigo mesmo que se seguem imediatamente daquele primeiro comando do autoconhecimento. ${ }^{52}$

\footnotetext{
150 TL 441

${ }^{151} \mathrm{KpV} 139$

152 TL 441
} 
Ao citar a nobre disposição para o bem que torna o homem digno de respeito, podemos compreender que Kant nos remete à disposição para o bem citada na Religion. Precisamente, a disposição à personalidade, pois: a) bane o desprezo pela humanidade; b) ressalta a importância da nobre disposição para o bem presente no ser humano; c) torna o homem digno de respeito. Ao banir o desprezo pela humanidade, valoriza essa mesma humanidade, sendo a remoção do obstáculo o estímulo positivo à ação que se segue. A nobreza da disposição se garante pela qualidade moral presente somente na disposição à personalidade e ausente nas duas outras. A dignidade resultante do respeito reside no cumprimento da lei e toma forma na personalidade. Kant prossegue indicando que o processo de autoconhecimento nos leva a confrontar a desprezível benevolência moral ${ }^{153}$ e a dar fim à presunção, abrindo espaço para o verdadeiro valor que reside na autoestima ancorada na virtude e que emerge da imparcialidade no julgamento de si perante a lei e da sinceridade da autoconfissão de seu valor moral.

Do respeito ao amor

Chama-se modéstia à moderação nas pretensões em geral, isto é, a limitação voluntária do amor de si mesmo [Selbstliebe] de um homem em vistas do amor por si mesmo [Selbstliebe] de um outro; a falta desta moderação (imodéstia) em relação ao merecimento de ser amado por outros chama-se amor-próprio [Eigenliebe] (philautia). A imodéstia da exigência de ser respeitado por outros é a arrogância [Eigendünkel] (arrogantia). Portanto, o respeito que tenho pelos outros, ou que um outro pode exigir de mim (observantia aliis praestanda), é também o reconhecimento de uma dignidade (dignitas) em outros homens, isto é, de um valor que não tem preço, que não tem equivalente pelo qual o objeto da estima (aestimii) pudesse ser trocado. A avaliação de uma coisa como algo que não tem valor é o desprezo [Verachtung]. ${ }^{154}$

Retomando o que fora conceituado já na Crítica da razão prática, Kant mais uma vez trata da relação entre amor de si [Selbstliebe], amor-próprio [Eigenliebe] e arrogância. Explicita ele a conotação pejorativa do termo Eigenliebe (amor-próprio), como uma Selbstliebe (amor de si) que não se limitou voluntariamente através da modéstia, processo que lembra a definição de amor no texto $O$ fim de todas das coisas como a livre adoção da vontade alheia sob minhas máximas. E de certo retomamos, enquanto modéstia, a humilhação provocada pela razão pura prática. Novamente, Kant retoma o tema da dignidade, da estima e do valor: respeitamos o sujeito moral no outro, bem como valorizamos em nós nosso sujeito moral. Por fim, vale registrar que a palavra alemã Verachtung (desprezo) é a negação do respeito (Achtung) ou seja, ao não

\footnotetext{
${ }^{153}$ Ethica - Teil B - p.150
}

154 TL 462 
reconhecer o valor de algo, não se está respeitando, dando atenção a este algo deixando de se prezar pelo mesmo. Porque, como encontramos na Ethica, "quem procurar em um humano o que neste seja digno de amor, certamente encontrará nele, algo que seja digno de seu amor"155|156. Quanto ao respeito, então, nem se precisaria procurar, pois o respeito ocorre diante da razão que habita em todos os seres racionais. Basta então dar atenção à racionalidade intrínseca de cada ser.

Todo homem tem uma legítima pretensão ao respeito de seus semelhantes e, reciprocamente, ele também está obrigado a este respeito em relação a todos os outros.

Fundando-se no respeito, naturalmente desenvolve-se o amor, uma vez que no fundo, segundo a lei, ambos estão sempre ligados entre si em um dever ${ }^{157}$. Considerando o mundo moral, os homens tendem a se aproximar continuamente entre si em virtude do princípio do amor recíproco e tendem a guardar distância entre si por meio do princípio do respeito ${ }^{158}$. O respeito em sentido prático é conseguido a partir da máxima da limitação de nossa autoestima por meio da dignidade humana em outra pessoa ${ }^{159}$ em um processo que remete a uma espécie de natural auto-regulamentação da liberdade.

\section{Da ideia do humano enquanto ser moral como lastro para o amor de si racional}

A humanidade é ela própria uma dignidade, pois o homem não pode ser usado por nenhum homem (nem pelos outros nem sequer por si mesmo) apenas como meio, mas tem sempre de ser ao mesmo tempo usado como fim, e nisto (a personalidade) consiste propriamente sua dignidade, por meio da qual ele se eleva sobre todos os seres do mundo que não são humanos e que podem certamente ser usados; e eleva-se, portanto, sobre todas as coisas. Logo, assim como ele não pode alienar-se a si próprio por preço algum (o que seria contrário ao dever de autoestima), do mesmo modo ele não pode agir contra a autoestima igualmente necessária dos outros enquanto humanos, isto é, o humano é obrigado a reconhecer praticamente a dignidade da humanidade em todos os outros homens, portanto, radica nele um dever que se refere ao respeito que se tem necessariamente de mostrar por todo outro humano. ${ }^{160}$

E este respeito vale para todo ser humano, independente da situação, pois até o vicioso pode melhorar e o que incorre em erros reconhecê-los e se

\footnotetext{
${ }^{155}$ Ethica - Teil B - p.215

${ }^{156}$ Und ein solcher, der an dem Menschen sucht, ob nicht etwas an ihm ist, was der Liebe würdig wäre, der wird auch gewiss was an ihm finden, was seiner Liebe würdig ist [...].

157 TL 448

158 TL 449

159 TL 449

160 TL 449
} 
endireitar. Afinal, desprezo e negação são incompatíveis com a ideia de um humano que enquanto ser moral, jamais pode perder toda disposição para o bem $^{161}$.

O respeito pela lei, que é designado subjetivamente como sentimento moral, é idêntico à consciência de seu dever. Precisamente por isso também a manifestação de respeito pelo homem enquanto ser moral (que estima seu dever acima de qualquer coisa) é, ela mesma, um dever que os outros têm perante ele e um direito a cuja pretensão ele não pode renunciar. Esta pretensão é chamada de amor à honra, e seu fenômeno na conduta exterior, honorabilidade (honestas externas). ${ }^{162}$

Ou, como lemos na Ethica: "nossas ações devem fluir a partir do amor à honra. [....] A honradez é a dignidade do comportamento de tornar-se digno de honra, quer dizer, não ser objeto de desprezo."163|164 Ou seja, devemos desenvolver uma estima de nós mesmos [Selbstschätzung] ligada à humildade ${ }^{165}$, amando ao próximo como a si mesmo. Amando a dignidade dos atos que o tornam, em alinho com o sumo bem, naturalmente a medida de relação que se estabelece na humanidade, passa a ser, ele mesmo enquanto ser moral, uma medida moral. ${ }^{166} \mathrm{E}$ isto, nada mais é do que o amor de si, que, humilhado, torna-se amor de si racional e exalta sua natureza sublime enquanto sujeito moral acima de toda natureza sensível.

\section{Da estima do amor de si racional}

A estima [Schätzung] é distinta do amor-próprio [Eigenliebe]. A estima recai sobre o valor interior, o amor sobre a proporção de meu valor em relação ao bem-estar. Estimamos aquilo que tem valor intrínseco e amamos aquilo que proporcionalmente tem valor; i.e. o entendimento [Verstand] tem um valor intrínseco, sem considerar aquilo a que é aplicado. Quem observa seus deveres, quem não desonra sua pessoa, é estimável, quem é sociável, é adorável [liebenswert]. O juízo pode nos imaginar ou adorável ou estimável. ${ }^{167 \mid 168}$

\footnotetext{
161 TL 464

162 TL 464

${ }^{163}$ Ethica - Teil B - p.206

164 Unsere Handlungen müssen aus der Ehrliebe fliessen. [...] Ehrbarkeit ist die Würdigkeit des Verhaltens, geehrt zu werden, d.h. kein Gegenstand der Verachtung zu sein.

${ }^{165} \mathrm{KpV} 231$

$166 \mathrm{KpV} 233$

167 Ethica - Teil B - p.148

${ }^{168}$ Von der Eigenliebe ist die Schätzung unterschieden. Diese geht auf den inneren Wert, die Liebe aber auf das Verhältnis meines Wertes in Beziehung auf das Wohlergehen. Wir schätzen das, was einen inneren Wert hat, und lieben das, was verhältnisweise einen Wert hat; z.E. Verstand hat einen inneren Wert, ohne zu erwägen, worauf er angewandt wird. Der seine Pflicht beobachtet, der seine Person nicht entehrt, ist schätzenswert, der gesellig ist, ist liebenswert. Es kann das Urteil von uns entweder liebenswert oder achtungswert vorstellen.
} 
Apesar de distintos,

podemos ter autoestima [Selbstschätzung] do amor-próprio [Selbstliebe], que seria tomar uma atitude favorável para consigo mesmo [Selbstgewogenheit] e auto-favorecimento [Selbstgunst]. Essa autoestima pragmática a partir de regras da inteligência é apropriada e possível, enquanto procura observar a segurança. Ninguém pode exigir que eu me rebaixe ou me sinta menor que outros, todos têm o direito de exigir, que o outro não se levante. Apenas a autoestima moral, que se baseia na dignidade da humanidade, não tem que se comparar com outros, mas se fundar por si mesmo na comparação com a lei moral. ${ }^{169 \mid 170}$

Kant afirma assim o amor-próprio [Selbstliebe] como validador relativo e agente de segurança, enquanto pragmático, bem como validador absoluto na avaliação de sua coerência com a lei moral, quando se trata de autoestima moral. Assim, a partir da autoestima do amor-próprio, dividida em pragmática e moral, Kant valida a primeira quanto à necessidade de segurança de nossa existência física e social e que podemos atribuir às disposições originárias do bem da animalidade e da humanidade. Isto viabiliza a validação da segunda como acesso ao sublime a partir da grandeza da moralidade humana ancorada na lei moral - e que podemos atribuir à disposição originária da personalidade ao bem. Devemos nos lembrar, mais uma vez, que na Crítica da faculdade do juízo Kant adverte que a contemplação do sublime ocorre quando nos sentimos seguros quanto à nossa integridade física. ${ }^{171} \mathrm{E}$ é na contemplação do sublime que ganhamos confiança em nossa força de subordinar nossas inclinações à lei em um constante progresso em direção ao bem. Por mais que seja necessária a revolução da maneira de pensar que ocorre em nossos corações ${ }^{172}$, a aplicação prática é uma reforma ${ }^{173}$ dos sentidos e ações, o que viabiliza a possibilidade do progresso para o bem mesmo diante da questão do mau radical. Para isto, basta manter-se diante de si a pureza da lei como caminho para elevar-se progressivamente de um amor-próprio que não somente transgride, mas

\footnotetext{
${ }^{169}$ Ethica - Teil B - p.140

170 „Wir können Selbstschätzung der Selbstliebe haben, welches Selbstgewogenheit und Selbstgunst wäre. Diese pragmatische Selbstschätzung nach Regeln der Klugheit ist billig und möglich, insofern sie die Sicherheit zu beobachten sucht. Keiner kann verlangen, dass ich mich erniedrigen und geringer als andere halten soll, jeder aber hat Recht zu fordern, dass sich der andere nicht erhebe. Allein die moralische Selbstschätzung, die auf der Würde der Menschheit beruht, muss sich nie auf die Vergleichung mit anderen, sonder auf die Vergleichung mit dem moralischen Gesetz selbst gründen."

${ }^{171} \mathrm{KU}$ B103 "Quem teme a si não pode absolutamente julgar sobre o sublime da natureza [...] contanto somente que nos encontremos em segurança"

172 Religion B61

${ }^{173}$ Religion B54
} 
subverte e distorce a lei a seu favor, para uma autoestima lastreada pelo exercício moral da virtude e que mantém respeito constante pela lei.

\section{Do amor universal como móbil moral}

Os humanos são movidos por dois móbiles, um é tomado por si só e é o móbil do amor de si [Selbstliebe]; o outro é o móbil moral que é tomado dos outros, e é o móbil do amor humano universal [allgemeine Menschenliebe]. Esses dois móbiles estão em conflito no ser humano. [...] é uma grande conquista, quando o humano é movido pelo amor humano universal a promover a felicidade alheia. No entanto, o humano se baseia especialmente naquilo que dá valor à sua pessoa. Dessa ideia flui a amizade ${ }^{174}$. [...] Parece que o humano perde [seu valor], quando cuida da felicidade alheia; somente quando outros cuidam dele, ele nada perde. Assim sendo, todos teriam sua sorte promovida pela generosidade alheia. Essa é a ideia da amizade, onde o amor de si é engolido pela ideia do generoso amor recíproco. ${ }^{175 \mid 176}$

O amor humano universal, representado pela amizade, inclui também o eu mesmo, sem o qual não há universalidade do conceito de humanidade à qual se pertence. Daí que podemos defender inclusive lógica e racionalmente a subordinação do amor-próprio ao amor humano universal. Kant problematiza a questão, buscando ainda maior clareza da relação amizade e amor-próprio, trazendo a questão universal da relação do indivíduo com o todo da humanidade, que é muito fácil de se tornar apenas mera conjectura, para a prática da relação com o outro, que como eu também representa a humanidade e com o qual lido de maneira direta.

Se tivesse então que escolher, o que escolheríamos? Amizade ou amor de si [Selbstliebe]? Por motivos morais escolheríamos a amizade, mas por motivos práticos o amor de si, pois ninguém poderia cuidar tão bem de minha sorte como eu. Mas se eu optar por um dos dois, então haverá sempre um erro. Opto apenas pela amizade, sofre assim minha sorte, opto apenas pelo amor de si, não reside aí nenhum mérito moral e valor. [...] O máximo do amor recíproco é a

\footnotetext{
174 "Freundschaft findet nicht im Himmel statt, denn Himmel ist die grösste moralische Vollkommenheit, und diese ist allgemein; Freundschaft ist aber eine besondere Vereinigung gewisser Personen, also ist dieses in der Welt nur Zuflucht, seine Gesinnung dem anderen zu eröffnen und sich ihm zu kommunizieren, indem man hier im Misstrauen gegeneinander steht." (Ethica - Teil B - p.223)

175 Ethica, Teil B - S.216-217

176 Die Menschen werden von zwei Triebfedern bewegt, eine ist von ihnen selbst hergenommen, und das ist die Triebfeder der Selbstliebe; die andere ist die moralische Triebfeder die von anderen hergenommen ist, und das ist die Triebfeder der allgemeinen Menschenliebe. Diese zwei Triebfedern sind bei dem Menschen im Streit. [...] es ist ein grosses Verdienst, wenn der Mensch durch allgemeine Menschenliebe bewogen wird, das Glück anderer zu befördern. Nun hält aber der Mensch besonders darauf, was seiner Person einen Wert gibt. Aus dieser Idee fliesst die Freundschaft. [...] Es scheint, als wenn der Mensch verliert, wenn er für das Glück des anderen sorgt; allein wenn andere wieder für inn sorgen, so verliert er nichts. Alsdann würde jedes sein Glück durch die Grossmut des anderen befördert. Dieses ist die Idee der Freundschaft, wo die Selbstliebe verschlungen ist in der Idee der grossmütigen Wechselliebe.
} 
amizade e esta é uma ideia ${ }^{177}$, pois serve à medida de determinação da reciprocidade do amor. O maior amor para com alguém é quando eu o amo como a mim mesmo ${ }^{178}$. [...] O humano cuida de si e também da sorte alheia ${ }^{179}$. [...] A relação da amizade é a relação da igualdade. ${ }^{180 \mid 181}$

Kant chama a atenção, através da conceituação do "maior amor" para a importância prática do amor de si e de como ele pode e deve ser utilizado para a promoção moral. Isso gera um princípio auto-regulativo de equilíbrio expansivo: meu amor-próprio e meu amor ao próximo delimitam-se em seu potencial e em sua natureza, indo ao máximo de suas possibilidades de coexistência, tendo, assim, um potencial moral devido ao princípio da igualdade. A moralidade dependerá então somente do princípio adotado. Considere-se ainda a conceituação de amor que Kant dá no texto O fim de todas as coisas: o amor como a livre adoção da vontade alheia sob a minha máxima ${ }^{182}$. Chegamos a uma interessante reflexão: se amar o outro como a mim mesmo é o maior amor e se posso entender o amor como a livre adoção da vontade alheia sob minha máxima, então a livre adoção da vontade alheia sob minha máxima terá o ápice de sua expressão quando amo o outro como a mim mesmo, identificando sua vontade, sua razão pura prática como a minha, sendo assim impossível haver qualquer traço de egoísmo por se tratar da manifestação pura da lei. Nesse sentido, ao subordinar sua razão pura prática sob minha máxima, aumento o grau de universalidade de minha ação, rumo progressivamente à perfeição moral conforme mais pessoas amo. O amor é, portanto, um ampliador da razão individual rumo à efetivação da razão pura, da qual é auxiliar. Quanto maior for a minha capacidade de me amar, acolhendo minhas próprias vontades sob minha máxima moral, maior será a capacidade de acolhimento da vontade alheia, pois meu amor para com o outro será proporcional ao meu amor-próprio (amor de mim racional). Todavia, como vimos acima, não há valor moral no amor de si, mas de certo, se nossa própria máxima for subordinada à lei - e Kant não exclui

\footnotetext{
177 Die Idee ist ein Mass; sofern es ein Muster anderer ist, so ist es ein Ideal. [...] Die Idee ist aber was wahres. (Ethica, Teil B - S.218)

${ }^{178}$ Ethica, Teil B - S.218

${ }^{179}$ Wenn nun aber jeder nur allein für sich sorgte, ohne für den anderen bekümmert zu sein, so würde gar keine Freundschaft stattfinden. Also muss beides untereinander gemischt sein.

${ }_{180}$ Ethica, Teil B - S.220

181 Wenn wir nun wählen sollten, was würden wir wählen? Freundschaft oder Selbstliebe? Aus moralischen Gründen würden wir die Freundschaft wählen aus praktischen aber die Selbstliebe, denn keiner könnte doch mein Glück so gut besorgen als ich. Wenn ich aber eins von beiden nehme, so ist doch immer was Fehlerhaftes. Wähle ich blosse Freundschaft, so leidet dadurch mein Glück, wähle ich blosse Selbstliebe, so ist darin kein moralisches Verdienst und Wert. [...] Das Maximum der Wechselliebe ist die Freundschaft, und diese ist eine Idee, denn es dient zum Mass, die Wechselliebe zu bestimmen. Die grösste Liebe gegen den anderen ist die, wenn ich inn so liebe als mich selbst. [...] Der Mensch sorgt für sich und auch für das Glück anderer. [...] Das Verhältnis der Freundschaft ist Verhältnis der Gleichheit.

${ }^{182} \mathrm{O}$ fim de todas as coisas - p.13
} 
esta reflexão em momento algum - por meio da aplicação da lei meu amorpróprio se torna amor de si racional e, assim, autoestima por levar em conta meu valor intrínseco de agir por princípios. Toda função inclusiva do amor de si racional de amar o outro como a si mesmo se canaliza então também moralmente a partir do estabelecimento da segurança do ser que não necessita se preocupar mais com sua sorte. Assim, passa a se relacionar com o outro na justa medida da igualdade. O que remete à disposição originária do bem enquanto personalidade e que garante por sua vez o anseio à igualdade da disposição originária do bem enquanto humanidade. Devemos, portanto, compreender que se trata do amor de si racional, que por sua característica racional subordinada à lei reconhece e respeita o outro como amigo baseado no princípio de igualdade da lei. A amizade baseada no princípio de igualdade da lei gera assim uma humanidade igualitária baseada no amor e no respeito, sentimentos necessários ao exercício dos deveres e que estabelecem relações críticas alternando entre aproximação e afastamento de acordo com cada situação. A amizade baseada na lei e exercida com respeito e amor promove um progresso constante rumo à paz perpétua, que é a manifestação do sumo bem e a realização das disposições originárias para o bem. Dentro de todo este contexto, o que compreendemos é que o amor de si está intrinsicamente ligado à humanidade.

Da confirmação da moralidade da humanidade pelo amor de si racional

O preconceito promove a conveniência e o amor próprio [Eigenliebe], duas características que não são colocadas de lado sem abrir mão da humanidade. ${ }^{183 \mid 184}$

O amor-próprio, aqui Eigenliebe, é descrito como característica humana e um fator que, junto com a conveniência, uma espécie de adequação à zona de conforto escolhida por cada um, turvam o entendimento frente às diferenças a partir de uma aparência de total igualdade à qual se relega os demais, após terse elevado determinados homens a alturas insustentáveis. É cômodo assegurarse com preconceitos e referenciar-se por nomes e títulos; deixa-se de observar, contudo, como se é superado até por aqueles que se encontram na mediocridade. Conveniência e amor-próprio representam respectivamente

\footnotetext{
${ }^{183}$ Vorkritische Schriften I, Vorrede, Seite 17 - Suhrkamp Taschenbuch

${ }^{184}$ Das Vorurteil ist recht vor den Menschen gemacht, es tut der Bequemlichkeit und der Eigenliebe Vorschub, zweien Eigenschaften, die man nicht ohne die Menschheit ableget.
} 
preguiça e covardia, justamente aquilo que nos impede de nos esclarecermos. Preguiça de pensar além de si mesmo, covardia de pensar a partir do elevado horizonte moral que se agiganta em nossa personalidade noumênica. Agora, se são intrínsecos e necessitam de esclarecimento, parece que é justamente disto que se trata o ato de humilhação do amor de si que o torna amor de si racional ao esclarecer seus limites e apresentar-lhe o sublime horizonte do sujeito moral, configurando assim também a moralidade da humanidade a partir da subordinação de cada indivíduo à moral. Todo o progresso se inicia no ato de conversão do coração, que passa a representar as leis com a devida subordinação das máximas. O coração acolhe a vontade alheia livremente sob a correta representação da Lei, garantindo a pureza das disposições originárias, formando um caráter inteligível, modo prático e coerente de agir de acordo com máximas morais imutáveis. O coração forja assim a relação necessária entre o respeito e o amor, garantindo a justa relação entre proximidade e distância para uma humanidade em progresso moral constante. E nesta relação "o que ocorre a um humano atinge também a mim" ${ }^{185}$.

Todavia,

Os homens que procedem segundo princípios são muito poucos, coisa que até é muito conveniente, pois com facilidade estes princípios são falseados, e então o perigo que disso deriva chega tanto mais longe quanto mais geral é o princípio e mais firme a pessoa que o adotou. Os que obedecem à vontade espontânea são em maior número, o que é bom, ainda quando não possa ser contado como um mérito particular da pessoa. Estes instintos virtuosos faltam por vezes: mas, por termo médio, cumprem perfeitamente o grande propósito da natureza, igualmente como os outros instintos, mercê dos quais se move com tanta regularidade o mundo animal. Os que como único ponto de referência para os seus esforços têm fixa ante os olhos a sua adorada pessoa [allerliebstes Selbst] e procuram fazer girar tudo em torno do seu egoísmo, como eixo maior, são o maior número, e isto vem a resultar também muito benéfico; estes, de fato, são os mais inteligentes, ordenados e precavidos; dão consistência e firmeza ao todo e, sem terem essa intenção, são úteis em geral enquanto facilitam as necessidades imprescindíveis e preparam as bases sobre as quais as almas delicadas podem estender a formosura e a harmonia. ${ }^{186}$

\footnotetext{
${ }^{185}$ Vorkritische Schriften II, S.841
}

${ }^{186}$ Vorkritische Schriften II, S.849 
Este texto pré-crítico parece destoar do pensamento kantiano como um todo, quando observamos a ascendência da moral sobre o indivíduo, mas dialoga com o que vimos quanto à disposição originária para o bem na Religion e oferece um caminho para entendermos como a Selbstliebe em sua forma progressiva (amor a si, amor de si e amor de si racional) auxilia à moralidade das ações. As duas disposições originárias ao bem que carecem de moralidade, a disposição à animalidade e a disposição à humanidade, se servem, respectivamente, do amor a si e do amor de si para rumar à moralidade encontrada na disposição à personalidade. Neste contexto, forma-se a ideia de humanidade - na qual me incluo e com a qual me identifico - em um progresso constante do estado de guerra da animalidade comprometida com a sobrevivência à paz perpétua da moralidade da personalidade que se afirma além do valor obtido da opinião alheia. Na moralidade que co-emerge com a personalidade, o valor pessoal emerge a partir da reverência à lei moral, superando assim a inclinação para obter para si um valor na opinião dos outros. Esse valor relativo é necessário, de início, para constituir a humanidade, mas há de se ir além da cultura que pode viciar e esconder e incitar inclinações. Há de se ter responsabilidade pela afirmação de seu valor além da comparação com o próximo, pautando-se somente pela lei inscrita em nosso coração. O que fica da reflexão quanto à relação indivíduo-humanidade é a comunicabilidade entre iguais, superando assim tanto o medo do outro the reivindicar superioridade quanto a inclinação de querer superar os outros para evitar qualquer prejuízo - o que evidencia a necessidade de superar sua fraqueza, seu medo, superando a si mesmo para agir de acordo com a parte maior de nós mesmos: a honra de exercer o bom caráter. Para que se tenha um bom caráter, vale lembrar, é necessário se cultivar a ideia de humanidade considerada de modo plenamente intelectual. Como esta disposição originária para o bem é puramente racional e moral, podemos deduzir que se trata do caráter inteligível, que, como já vimos, é o modo prático e coerente de pensar segundo máximas imutáveis ${ }^{187}$. Se entendermos honra como reverência e coerência a seus valores propostos a si mesmo, podemos compreender a expressão 'agir por honra ao bom caráter', a ação que age por algo maior que eu mesmo, pela humanidade, que me inclui e à qual contribuo com a singularidade do exercício moral de minha personalidade, meu valor. E este exercício é alicerçado por máximas imutáveis forjadas pela pureza da lei enquanto princípio e pela imagem de humanidade que guardo em

${ }^{187} \mathrm{KpV} 271$ 
mim como valor a afirmar a cada interação que me tenta pela inclinação ex data da humanidade na qual estou inserido em oposição à vontade ex principii ${ }^{188} \mathrm{da}$ humanidade à qual aspiro e que se agiganta no jogo de minhas faculdades e enobrece minha alma de poder ser exemplo prático da pureza moral. Essa busca já serve de modelo e apoia a ação moral, mas é justamente a publicidade da máxima que garante a ação justa, como lemos no segundo tópico do apêndice do livro Rumo à paz perpétua ${ }^{189}$. Isto deveria bastar para garantir o pensamento e ação além do proveito próprio a si mesmo. Mas, para garantir a força moral, a humilhação que sofremos ao sermos expostos à grandeza da natureza, bem como à magnitude da lei, assegura a quem a este sentimento moral se expõe a inscrição de sua conduta prática em ressonância com a lei a partir da prática da virtude. E torna o amor de si, amor de si racional, retirando-nos o excesso, cultivando em nós o necessário.

\section{Da ampliação do belo e da dignidade pela comunicabilidade}

Podemos relacionar ao belo e sua comunicabilidade a proximidade do amor, bem como à publicidade da máxima que conduz às ações justas que tornam equânime as relações da humanidade em sociedade - o que daria conta dos anseios da primeira e da segunda disposição ao bem, a disposição à animalidade e a disposição à humanidade. Podemos, também, relacionar ao sublime, a distância do respeito, que evoca o sentimento moral necessário para o exercício da personalidade. Isto dimensiona o sujeito entre os sistemas sobre sistemas e toda força da natureza, revelando a força moral que o possibilita afirmar sua vontade acima de todas as inclinações a partir da lei inscrita em nossos corações.

Finalmente o amor pela honra acha-se no coração de todos os homens, ainda que em medida diferente, e presta ao conjunto uma encantadora beleza, próxima do maravilhoso. ${ }^{190}$

O efeito do sublime aniquila a presunção e deixa o amor pela honra conforme a lei, elevando a existência comum e comunicável a todos à ordem maravilhosa do sublime.

\footnotetext{
${ }^{188} \mathrm{KrV} \mathrm{B} 864$

${ }^{189}$ ZeF página 109

190 Vorkritische Schriften II, S.849
} 
Ainda que o desejo de honra [Ehrliebe ${ }^{191}$ seja uma louca quimera quando se converte em regra à qual se subordinam as outras inclinações, como impulso concomitante resulta muito útil. ${ }^{192}$

Kant evidencia neste trecho a importância do amor à honra como impulso útil, ao qual podemos relacionar as duas primeiras disposições do bem que conduzem à moralidade. Mas ressalta a ameaça que o amor à honra representa se se tornar regra à qual se subordinam as outras inclinações, justamente por ser também uma inclinação e poder determinar um erro na hierarquia das máximas, resultando no mau. É necessário aniquilar toda presunção antes e garantir a pureza da honra, não a si enquanto fenômeno, mas ao sujeito moral, ao noumeno que se confunde com a lei.

Cada qual, ao realizar os seus atos no grande cenário social, segundo as suas inclinações dominantes, vê-se movido por um impulso secreto a tomar mentalmente um ponto de vista fora de si mesmo para julgar a aparência do seu proceder, tal como se apresenta à vista do espectador. ${ }^{193}$

Mesmo em meio às inclinações dominantes que emergem da comparação empírica na e da humanidade, vemo-nos movidos por um impulso secreto que nos conduz à máxima do senso comum já abordada nesta dissertação e que visa ao alargamento da mentalidade, encaminhando à moralidade: tomar mentalmente um ponto de vista fora de si mesmo para julgar a aparência, ou seja, a estética de seu proceder, tal qual se apresenta aos olhos de um espectador, buscando assim um juízo reflexivo sobre si mesmo e que se compara com a ideia de humanidade que se projeta a partir da moral inscrita como base para as máximas imutáveis. É na figura do espectador ${ }^{194}$ que, como apontado por Hannah Arendt, se compartilha a faculdade do juízo e se faz uso da imaginação enquanto operação de reflexão ${ }^{195}$. Nesta operação, entra em questão o belo presente à minha ação e aponta-se à intersubjetividade ${ }^{196}$ do prazer desinteressado da ação ${ }^{197}$ : ter prazer na existência desta ação além de qualquer interesse próprio, onde o único interesse é aquele que se realiza em sociedade $^{198}$.

\footnotetext{
191 Sugiro tradução mais apropriada: amor à honra, posto que desejo de honra está mais para Ehrbegierde, termos que Kant diferencia claramente principalmente na Vorlesung über Ethik e na Doutrina da Virtude

192 Vorkritische Schriften II, S.849

${ }^{193}$ Vorkritische Schriften II, S.849

${ }^{194}$ Lições sobre a filosofia política de Kant, p. 64

195 Lições sobre a filosofia política de Kant, p. 65

${ }^{196}$ Lições sobre a filosofia política de Kant, p. 68

197 Lições sobre a filosofia política de Kant, p. 69

${ }^{198}$ Lições sobre a filosofia política de Kant, p. 74
} 
Os diversos grupos unem-se assim num quadro de expressão magnífica, onde a unidade transparece na grande diversidade, o conjunto da natureza moral mostra-se em si belo e digno. ${ }^{199}$

A beleza do conjunto humano e a sublime dignidade da personalidade são alcançados somente quando realizamos a manifestação do sublime em nós, ou seja, quando aniquilamos a presunção - o amor próprio - e visualizamos o valor da humanidade que emerge em nossas ações, morais por princípio, sem sofrer a ação das inclinações. Eis que o agir por honra se confunde com o amor de si mesmo racional, posto que é honra pelo sujeito moral que somos ao contribuir com o valor da nossa personalidade à moralidade. $O$ contexto em que aparece a expressão "adorada pessoa", em alemão "allerliebstes Selbst", cuja tradução mais precisa seria "seu eu mais amado", é o do debate acerca do proveito próprio (Eigennutz). O proveito próprio limita a experiência e a troca às questões mais objetivas e mundanas, ou seja, à humanidade no âmbito da comparação fenomênica, em detrimento de temas mais amplos e universais das quais a moral dá conta no exercício de valorização da humanidade pelo cultivo da personalidade. $O$ exemplo citado por Kant junto a esta passagem em seu livro ${ }^{200}$, quando o debate acerca das estrelas fixas é preterido pelo entendimento de como o arado é conduzido da maneira mais proveitosa, é preciso neste sentido. Todavia, apesar de reprovar claramente a ação em proveito próprio, Kant afirma que a preocupação de como a ação é percebida pelo público, sua comunicabilidade, leva a uma possibilidade de acordo dos diferentes grupos humanos, ressaltando em meio à diversidade a unidade, revelando a natureza moral da totalidade do todo através da beleza e da dignidade. Kant confere com este texto, portanto, um lugar - de certo não o de princípio ou máxima - ao amor de si dentro da beleza e dignidade da natureza moral, atribuindo-lhe características de constância e firmeza, através da inteligência, ordem e precaução; não à toa, veremos na Crítica da razão prática que a máxima do amor de si é a prudência ${ }^{201}$. Porquanto não é princípio moral, Kant aponta neste escrito para a importância do amor à honra e para a relevância do amor-próprio no cenário da moralidade como características sobre as quais se edifica a harmonia formosa do todo. O amor à honra estimula a comunicabilidade da ação moral e o amor de si mesmo serve como base para o sentimento moral a priori, como já evidenciado neste trabalho. Ressaltemos que quando há aniquilação da

\footnotetext{
${ }^{199}$ Vorkritische Schriften II, S.849

${ }^{200}$ Vorkritische Schriften II, S.849

${ }^{201} \mathrm{KpV} 64$
} 
presunção, o amor de si mesmo se torna racional não por adquirir algo, mas por perder excessos, ou seja, o amor de si racional é natural e anterior à humilhação oriunda do respeito à lei: o amor de si racional é a semente do sujeito moral que é cultivada pelo respeito para florescer ação moral. $O$ amor de si mesmo racional sucede o amor de si mesmo após o exercício da humilhação, mas é anterior, ou melhor interior a este processo, uma vez que a humilhação retira o excesso do amor de si mesmo, deixando apenas seu núcleo racional, que sempre esteve presente, tal qual se retira um véu ou uma casca.

Vemos pela primeira vez, em termos de cronologia das publicações de Kant, o uso muito próximo dos conceitos de amor à honra [Ehrliebe] e amor próprio, na figura do termo "eu mais amado", indicando que a preocupação com ações honrosas, que advém do amor próprio e da preocupação com a percepção alheia e seu julgamento frente às nossas ações, são muito úteis para o conjunto da natureza moral. Kant ressalta, contudo, antecipando a clareza com que define a ação moral ao longo de toda sua obra, que "nas qualidades morais só a verdadeira virtude é sublime" e que

\begin{abstract}
A verdadeira virtude, portanto, somente pode descansar em princípios que, a fazem tanto mais sublime e nobre, quanto mais gerais. Estes princípios não são regras especulativas, mas a constância de um sentimento que vive em todo o peito humano, e cujo domínio é muito mais amplo do que o campo da paixão ou da complacência. Creio recolher todo o seu conteúdo dizendo que é o sentimento da beleza e a dignidade da natureza humana. O primeiro é o sentimento da benevolência geral; o segundo, de estima geral; se este sentimento alcançasse a máxima perfeição num coração humano qualquer, este homem amaria e estimaria certamente a si próprio; mas somente como fazendo parte de todos aqueles a quem se estende o seu amplo e nobre sentimento. Somente subordinando-nos a esta inclinação tão ampla, podemos aplicar proporcionalmente os nossos bons instintos e produzir o nobre decoro que constitui a beleza da virtude. ${ }^{202}$
\end{abstract}

Kant neste escrito pré-crítico, ainda não cunhou o termo sentimento moral, mas podemos compreendê-lo a partir da relação que se estabelece na explicação da verdadeira virtude. A nobreza e sublimidade da virtude dependem diretamente da amplitude de seus princípios, ou seja, de sua universalidade. Não são especulativos, mas são princípios que se fundam na constância de um sentimento humano para além das inclinações e que se define pela beleza da

${ }^{202}$ Vorkritische Schriften II, S.836-837 
benevolência geral e a dignidade da estima geral, a beleza e dignidade da natureza humana, cuja disposição originária para o bem se ancora na evolução do amor de si. O lugar deste sentimento é o coração, sua moralidade dependente da pureza e universalidade de seus princípios ancorados na perfeição da natureza humana, atingível somente enquanto espécie. Ao alcançar a perfeição humana, tal sentimento moral nos faria amar e estimar a nós mesmos enquanto extensão do amor e da estima à humanidade da qual fazemos parte. É interessante ressaltar a menção de "inclinação tão ampla" em referência ao sentimento moral a qual devemos nos subordinar para aplicar proporcionalmente nossos bons instintos, produzindo o comportamento digno que dá forma à beleza da virtude, força interior principiada na sublime razão. Kant indica aqui a subordinação ao sentimento moral, princípio subjetivo da lei e que, como vimos neste trabalho, nasce da humilhação do amor de si, despertando o amor de si racional.

Vimos ao longo deste trabalho um aparente conflito entre a moralidade e o amor de si, resultando deste confronto o amor de si racional. Trata-se, certamente, de uma evolução crítica das disposições humanas a partir do antagonismo do qual a natureza se serve para obter o progresso moral ${ }^{203}$, ora agindo mais por respeito, ora mais por amor. A ação alternada entre respeito e amor fica evidente na sociabilidade insociável dos humanos. Vemos a força atrativa do amor que une os homens em seu impulso à sociedade, esta disposição originária do bem que é amor a si enquanto disposição à animalidade. Encontramos o respeito que guarda distância entre as pessoas ${ }^{204}$ na resistência universal que ameaça dissolver a sociedade, o que podemos remeter à disposição à humanidade, ao amor de si que se compara no nível fenomênico com o próximo (ao invés de buscar elevação na comparação noumênica com a lei, como ocorre na disposição à personalidade). $E$ como vive este conflito interno que se desdobra no externo, o ser humano precisa de um senhor $^{205}$, por tal motivo necessita tornar-se soberano de si mesmo para, a partir de sua personalidade que se dá leis, construir as condições para desenvolver integralmente todas as disposições da humanidade - a começar por si mesmo. A ideia da razão, mesmo que seja algo inexequível, deve ser algo ao qual rumamos e do qual nos aproximamos constantemente, promovendo nosso progresso e o desenvolvimento constante de nossas disposições. Diante deste

\footnotetext{
203 Idee - quarta proposição

204 TL 449

205 Idee - sexta proposição
} 
quadro de antagonismo que gera movimento e progresso moral, deve-se questionar se não é a relação entre o amor de si e a razão, algo que nos estimula a encontrar, no seu inevitável antagonismo, um estado de tranquilidade e de segurança no qual progressivamente se amplia o entendimento humano e se progride à paz perpétua do sumo bem. $O$ aparente antagonismo entre amor de si e razão desenvolve a disposição originária do bem do amor de si até que se obtenha o amor de si racional, onde amor e respeito à lei estão indissociáveis no amor à lei que garante a reciprocidade das relações e estabelece assim as bases para um progresso humano fraterno a partir do cultivo do amor pelo respeito à lei. Vamos assim da animalidade à humanidade equânime por meio do desenvolvimento da personalidade. Tal qual felicidade e virtude, que têm sua ligação a partir do sensível com a obediência à lei, se efetuam no suprassensível com a realização do sumo bem, podemos afirmar que no nível suprassensível amor e razão são um só, sendo o respeito o amor celeste espiritualizado ${ }^{206}$, como afirmou o editor da Felix Meiner Verlag para a obra Religion. Pois vejamos como pode haver uma passagem do amor de si ao amor de si racional que se equipara ao respeito. Inicialmente, o amor de si começa como fundamental para a) assegurar a segurança física; evolui para b) garantir a igualdade perante os indivíduos; tem como disposição natural c) viabilizar o entendimento a priori do sentimento moral; e atua como base para d) contemplar a natureza sublime de nosso sujeito moral, quando se torna amor de si racional e estabelece uma universalidade similar à razão. Quando estabelece a universalidade similar à razão, cumpre-a com satisfação, pois não registra diferença entre si e o outro, entre o fim e o dever, entre o necessário e o desejável: o cultivo do amor de si para o amor de si racional não visa abolir a lei, mas antes cumpri-la. Uma proposta de evolução da lei na direção do amor, da passagem de um imperativo categórico puramente moral a um imperativo categórico ligado ao sentimento de fraternidade e simpatia, alicerçado na moralidade; tal imperativo traz em si uma exigência de absoluta equidade. Reforçando que quando

não se trata só da representação do dever, mas do cumprimento do dever, quando se indaga o fundamento subjetivo das ações do qual, se for possível prevê-lo, se deve esperar primeiro o que o homem fará, e não apenas o fundamento objetivo, isto é, o que ele deve fazer, o amor será então, enquanto livre acolhimento da vontade de outrem submetido às suas máximas, um complemento indispensável da imperfeição da natureza humana (para tornar

\footnotetext{
${ }^{206}$ Religion B11 Anmerkungen des Herausgebers
} 
necessário o que a razão prescreve mediante a lei): [...] sem a participação do amor, não se poderia contar muito com este [o dever] enquanto móbil. ${ }^{207}$

Registre-se que Kant guarda um lugar fundamental ao amor, pois sem o amor não se poderia contar com o dever enquanto móbil. Ademais, se o amor é aquilo que indica o que faremos primeiro, como lemos acima, e se em termos de benevolência e de deveres sou o mais próximo de mim mesmo ${ }^{208}$, sendo os deveres para consigo mesmo condição para cumprir com os deveres para com o próximo ${ }^{209}$, então é imperativo que eu ame a mim mesmo para cumprir com satisfação os deveres para comigo mesmo e assim poder cumprir com os deveres para com os outros. E se o amor é a livre adoção da vontade alheia sob a nossa máxima, isto é um reforço da moralidade de nossa máxima, uma disposição à moralidade, pois vejamos. A vontade é compreendida como razão pura prática, sendo assim, ao adotarmos a razão pura prática alheia sob nossa máxima, automaticamente estamos progredindo em direção à moralidade, sendo o amor uma ideia da imaginação que converge à razão. Se aplicarmos isto ao processo do pensamento baseado nas três máximas do senso comum, temos um sistema de incentivo à moralidade que converge pensamento racional e amor em um confronto de esclarecimento mútuo das intenções que nos motivam. Ao amar eu me torno mais racional, pois adoto a razão pura prática sob as minhas máximas, progredindo assim à moral. O amor então é um ampliador da razão particular à razão universal em um progresso constante do cultivo moral. Todavia, é necessário que para isto a razão tenha conformado o amor de si em amor de si racional, concebendo o amor-próprio dentro dos limites da lei, uma vez que, como vimos, o amor de si racional serve de parâmetro para o amor recíproco e este espelha no singular de cada relação, o que o amor à humanidade configura no universal. Realizar, portanto, o amor de si racional pode ser comparado à supremacia sobre si mesmo, já que

A supremacia ${ }^{210}$ sobre si mesmo é o maior dever consigo mesmo. A soberania sobre si mesmo consiste em subordinar todos os princípios e capacidades ao nosso livre arbítrio [...]: de acordo com a regra da prudência e da moralidade. De fato, toda regra da prudência se baseia na regra do razão, sendo que aqui a regra da razão serve à sensibilidade, conferindo-lhe os meios pelos quais as

\footnotetext{
${ }^{207} \mathrm{O}$ fim de todas as coisas p.13

208 TL 452

209 Ethica - Teil B - p.131

${ }^{210}$ Se existe um comando nosso sobre nós mesmos, há algo superior que pode ser identificado com o homo noumenon, sendo o homo phaenomenon nossa parte sensível, inferior, a ser convergida sob a ideia da moral.
} 
inclinações serão satisfeitas, porque em consideração a seus fins, depende da sensibilidade. A verdadeira soberania sobre si é a moralidade. [...] No entanto, este domínio de si repousa na força do sentimento moral. ${ }^{211}$

Vimos anteriormente que o maior dever para consigo enquanto ser moral é agir sempre segundo princípios, sendo-nos proibido privar da liberdade interna. A liberdade, por sua vez, nos obriga, como já mencionado anteriormente, ao dever do amor de si racional, que é ser fim para si mesmo. Assim sendo, o amor de si racional abre caminho para o homem moral qualificar seu fim, colocando-se fins pelo princípio da liberdade assegurado pelo dever do amor de si racional. Ou seja, a aplicação prática da liberdade repousa no dever do amor de si racional. Tanto quanto a supremacia de si repousa na força do sentimento moral. O que remete à gênese de ambos quando da humilhação da consciência por parte da razão pura prática. Ademais, como lemos na Religion, devemos produzir uma alegre disposição de ânimo sem a qual nunca estaremos certo de amar o bem, ou seja, de ter acolhido o bem em nossa máxima.

Funda-se nesta advertência, relevante para a moral: a liberdade do arbítrio tem a qualidade inteiramente peculiar de ele não poder ser determinado a uma ação por móbil algum a não ser apenas enquanto o homem o admitiu na sua máxima (o transformou para si em regra universal de acordo com a qual se quer comportar); só assim é que um móbil, seja ele qual for, pode subsistir juntamente com a absoluta espontaneidade do arbítrio (a liberdade).

Daí que a supremacia de si mesmo é a escolha consciente de suas máximas, tendo por princípio o respeito à lei e no amor a conduta que adota o bem em suas máximas. Em suma e como vejo: a razão leva em conta as exigências de nosso coração, esclarecendo conceitos e motivações, estabelecendo limites objetivos da ação moral e confiando à fé racional a disponibilização das forças para o primeiro móbil subjetivo do sujeito moral, o amor à honra, a vontade que busca se honrar. O diálogo entre razão e coração confirma assim a humanidade (ou não) do sujeito moral em ação, estabelecendo seu valor (dignidade ou preço) - tendo como fiador os três postulados da razão: Deus, a alma imortal e o mundo. Conceitos que por delimitação da dissertação não poderei esmiuçar, mas que para nosso uso basta ser compreendidos como garantias para o correto modo de pensar moral, respectivamente sendo a garantia da possibilidade da relação recíproca entre virtude e felicidade, a garantia da possibilidade de progresso infinito e a possibilidade de pensar um

${ }^{211}$ Ethica - Teil B - p.151/153 
todo interligado, um espaço finito da aplicação relativa do valor absoluto e que serve de interface para a manifestação da virtude. O amor então é a emergência moralizada das paixões, é a convergência das inclinações à moral (sistema de todos os fins) a partir do respeito à lei; é a vitória da vontade sobre si mesma. O amor é sustentabilidade enquanto a vontade se sustenta ao reafirmar-se consciente de si - é a vitória da razão sobre todas as inclinações, o cultivo do coração alegre que dispõe o ânimo à moral. $E$ isto tudo ocorre somente porque aprendemos a nos amar: não mais enquanto animais, mas a reconhecer nosso valor enquanto legisladores de nosso mundo, cultivando a liberdade a cada ato. Realizamos o amor de si mesmo racional, um lastro moral na relação humana, caminho à interação moral que agrega valor ao mundo e desenvolve assim suas disposições para o bem. O amor de si mesmo racional é a garantia da pureza da razão pura prática ao delimitar o sentimento moral de um lado e a humilhação do outro, concebendo em si o respeito à lei. 


\section{5 \\ Conclusão}

Procurar ser virtuoso para ser digno de ser feliz e progredir em direção ao sumo bem, isto é, procurar não ceder às inclinações é o caminho que Kant aponta para a moralidade. O caminho que visa dar forma racional ao amor de si. É justamente na queda da presunção, na destruição da arrogância, que com sua ilusão, vedava nossa visão, ocupando-nos com nossa ilusória grandeza e impedindo-nos de ver o valor das pessoas e do mundo, que se abre o espaço para o cultivo de nosso verdadeiro valor: o acordo de nossa ação com os princípios morais. Se, por um lado, a valorização só é possível pelo aniquilamento da arrogância, por outro, a contemplação do valor mais sublime da natureza humana só ocorre pela segurança dos limites justos e conformes à lei que o amor de si racional nos assegura, uma vez que só se pode contemplar as forças sublimes acreditando-se estar em segurança, o que vale também para a contemplação de nossas disposições para o bem.

Neste trabalho, apresentamos o amor de si racional como sendo necessário para a filosofia prática kantiana, que ainda que não possa abrir mão do conceito de razão e de lei, no que concerne aos seus princípios, precisa do conceito de amor para que a lei possa ser efetivada dentre os seres humanos. Apresentamos no primeiro capítulo uma chave de leitura para entender o amor de si como progresso moral na relação entre dever e liberdade ao compreendermos o conceito kantiano de dupla personalidade presente na unidade humana (numero idem). A existência de dois "si mesmos", um noumênico e outro fenomênico, abre a possibilidade - que pretende ter sido confirmada - de se poder amar-se a si mesmo de suas maneiras. O amor de si mesmo fenomênico ao homo phaenomenon e o amor de si mesmo racional pelo homo noumenon. A relação constante entre estas duas naturezas humanas é o antagonismo do qual a natureza se serve para obter o progresso moral.

No segundo capítulo, vimos a importância e necessidade da pureza da lei moral como princípio de escolha das máximas, bem como avançamos no entendimento do que é a Selbstliebe, o amor de si, e como ele é uma combinação de presunção e de amor-próprio. Avançamos no entendimento de que a presunção é aniquilada pela razão pura prática e dá vazão ao amor de si racional, um amor-próprio cultivado nos limites da lei, que assegura a 
contemplação de nossa natureza sublime. O amor de si racional se coloca fins e se dá leis baseadas em princípios morais suprassensíveis que representam a máxima de nossa liberdade voltada a um bem comum duradouro. Vimos que sem o aniquilamento da presunção pela razão, o amor de si é fonte de todo mau enquanto for o princípio ordenador das máximas, passando da presunção à arrogância de fazer de sua satisfação condição para cumprimento da lei. Por sua vez, o amor de si é também disposição originária para o bem, por dispor o ser humano para, a partir da animalidade de um amor irracional, servo das inclinações, evoluir a um amor racional. Na sociedade, em função da igualdade perante a lei, e tendo esta como medida, o ser humano desenvolve, através do amor de si racional, a personalidade e com esta a autoestima por estar ciente de sua ação moral e de sua existência enquanto sujeito moral. Justamente esta ideia de humanidade em nós é que legisla a partir da razão incondicionada, desinteressada quanto aos fins mais próximos e destemida no enfrentamento das inclinações. É a personalidade que é apta, portanto, a ações belas pautadas pela comunicabilidade da razão e pela contemplação da sublime natureza suprassensível humana que nos entusiasma e impulsiona ao progresso constante. É graças ao amor de si que sentimos a priori o efeito da lei, pois ao humilharmo-nos em nossa parcela fenomênica, exaltamos nossa condição noumênica de sujeito moral livre para se colocar fins a partir de princípios. É nesta condição de numero idem, da unidade do ser humano que habita tanto a natureza fenomênica como homo phaenomenon quanto a liberdade noumênica enquanto homo noumenon, que reside a possibilidade de compreendermos o amor de si enquanto um progresso moral do si à humanidade: amamos inicialmente a nós mesmos e isto nos assegura nossa sobrevivência animal; ao que podemos relacionar a disposição originária do bem que Kant chama de animalidade. Progredimos em direção ao amor recíproco da amizade, na qual amor e respeito são igualmente recíprocos, ${ }^{212}$ na relação entre pares dentro de uma sociedade com vistas à humanidade; ao que podemos atribuir a segunda disposição para o bem, a disposição para a humanidade. Ao adotarmos a amizade na intenção, tornamo-nos dignos de sermos felizes através de uma união puramente moral ${ }^{213}$ - o que assegura o estabelecimento da humanidade em progresso constante à paz perpétua do sumo bem, ao qual podemos atribuir a terceira disposição originária do bem, a da personalidade. 
Só não podemos cair, por preguiça ou por covardia, na armadilha da presunção e da falta de coragem que surge por nos afastarmos da lei moral ${ }^{214}$, pois isto pode nos levar a fazer deste amor de si nosso princípio legislador, o que, como vimos, é a fonte de todo mau. Eis um ponto digno de esclarecimento: o amor de si deve estar contido dentro dos limites da simples razão e assim servir como disposição à ação moral enquanto medida na relação do amor recíproco, como vimos no terceiro capítulo, no qual abordamos a hipótese do amor de si racional ser o equivalente ao amor à lei. Pretendemos tê-lo comprovado por meio de um argumento amparado em citações da obra de Kant: se o amor de si racional só é possível pela aniquilação da presunção, o que possibilita o reconhecimento a priori da lei e que por sua vez é o início do sentimento moral de respeito perante a lei, nos amamos moralmente enquanto conscientes de nosso ser moral. Se, enquanto sujeito moral, somos nós que nos colocamos a lei, a amamos enquanto livremente a adotamos em nossas máximas e a cumprimos com satisfação, o que configura tanto a definição de amor prático da Crítica da razão prática, quanto a definição de amor contida em fim de todas as coisas.

O amor de si é um sistema que serve à satisfação das inclinações por uma saciedade imediatista do ego. Quando a razão pura prática aniquila a presunção, evitando a arrogância, e limita o amor-próprio à moralidade, estabelece-se o amor de si racional. Ora, se o amor de si era um sistema que visava a satisfação das inclinações, porque não imaginarmos que o amor de si racional permanece um sistema, só que agora dentro dos limites morais? Sendo inclusive melhor subjugar o ponto de convergência de todas as inclinações, o ego, porquanto se subjuga todas as inclinações à lei, do que superar as inclinações uma a uma em uma batalha sem fim e sem perspectiva de êxito. No mesmo contexto da referência 129 da Crítica da razão prática, vemos que toda autoestima baseada na sensibilidade é aniquilada junto à presunção, o que abre espaço para o cultivo da autoestima a partir do respeito à lei, já que o valor do ser humano se pauta por aquilo que se faz ${ }^{215}$. Como vimos, amor e respeito são sentimentos que acompanham o exercício dos deveres ${ }^{216}$. Vimos também que o respeito vem primeiro, por ser um sentimento decorrente do cumprimento da lei, possibilitando, por sua vez, o amor verdadeiro que, nas palavras do próprio Kant,

\footnotetext{
${ }^{214}$ Ethica - Teil B - p.141

${ }^{215}$ Ethica - Teil B - p.174

216 TL 448
} 
torna necessário o que a razão prescreve mediante a lei ${ }^{217}$. Ora, é justamente o que ocorre com o amor de si racional: primeiro o respeito impõe a humilhação ao amor de si, aniquilando toda presunção, o que abre espaço para o cultivo do amor verdadeiro, o amor à lei, desinteressado e destemido. Temos diante de nós um belo e sublime sistema do amor de si racional que pode ser chamado então de sistema da felicidade moral baseado no progresso virtuoso, em suma, um sistema de sumo bem: a) o amor de si organiza as inclinações dentro de um cenário de satisfação; b) o amor de si sofre a ação da razão pura prática, ensinando o ser humano a sentir sua própria dignidade a partir da aniquilação da presunção; c) o ser humano consegue sentir a lei moral a priori como resultado da aniquilação; e) o amor de si passa a ser chamado de racional por se enquadrar dentro dos limites da moralidade; f) o amor de si racional só é possível através da consciência de ser sujeito moral e do fato de ele agir em convergência ao sumo bem; g) o amor de si racional encontra-se no coração ${ }^{218}$, onde a razão inscreveu sua lei ${ }^{219}$ e onde a força motriz da representação pura da virtude é o móbil mais poderoso e único móbil do bem em si tratando da duração e da diligência na observância das máximas morais ${ }^{220}$; h) o amor de si racional, possível em função do aniquilamento da autoestima baseada na sensibilidade (que gera toda presunção), se baseia no sujeito moral e ama a lei por si mesmo dada; com isso ele possibilita o cultivo da autoestima, baseada na dignidade humana, presente em cada ato. Pois vejamos: tendo como lastro o amor de si racional, que traz consigo o amor à lei que representamos enquanto sujeito moral que somos, e sendo o amor de si racional uma medida para o amor ao próximo em relação recíproca, temos que o amor de si racional é a medida para o alargamento do entendimento humano. $O$ amor de si racional é também a base para a edificação da humanidade, pois tem em si tanto o amor, quanto o respeito. O amor, vale ressaltar, é a disposição originária para acolher livremente a vontade alheia sob nossa máxima e que nos (e)leva da animalidade ao impulso à sociedade sem racionalidade alguma envolvida. Já o respeito é oriundo da via racional humana, da lei, e será fundamental no estabelecimento da igualdade nas relações sociais visando uma humanidade justa e equilibrada em constante progresso. Amor e respeito constituem a base de sentimentos, necessária ao exercício dos deveres e compreendem as três disposições para o bem, elevando-nos gradativamente da animalidade irracional à personalidade. É

\footnotetext{
217 O fim de todas as coisas - p.13

218 Religion B59

${ }^{219}$ Religion B116

${ }^{220} \mathrm{KpV} 272$
} 
a personalidade forjada pelo amor e pelo respeito que converge a uma humanidade igualitária a partir da medida da lei, passando pela fase de racionalidade fenomênica na comparação entre indivíduos em sociedade, este momento do ciclo de elevação da condição humana nos torna facilmente reféns da covardia, da preguiça e do medo. A comparação entre indivíduos em sociedade é justamente um caso no qual pensar por si mesmo, visando o esclarecimento de suas intenções, vontades e motivações, auxilia no desenvolvimento e ampliação do entendimento humano. A saída da menoridade por meio do esclarecimento estabelece uma humanidade que utiliza a emulação da competitividade em harmonia com o amor recíproco para construir uma sociedade em constante progresso moral. Somente um indivíduo, tendo vivenciado a liberdade como sujeito moral, pode construir sua justa autoestima e assim ter consciência do seu poder para conceber o progresso constante da razão. Este progresso constante, alinhado e alicerçado pelo amor recíproco, permite a passagem da animalidade à personalidade a partir da aniquilação da presunção por parte da razão pura prática e do estabelecimento do amor de si racional. Ou seja, é o amor de si racional que serve de medida para o amor recíproco alicerçar o progresso da razão concebido pela justa autoestima. E é a autoestima baseada no amor de si racional que possibilita estabelecer relações de igualdade lastreadas pela lei moral.

O amor de si [Selbstliebe] é, portanto, vital para o progresso moral na medida em que viabiliza o reconhecimento da lei, servindo de base para a manifestação do sentimento moral do respeito. Quando o respeito se manifesta, concomitantemente $\mathrm{o}$ amor de si se torna racional, passando este a ser combustível para a lei tornar-se ato, sendo um incentivo prático-moral para cumprir com satisfação o dever. $O$ amor de si então não tem apenas efeito negativo, quando por sua ausência acaba por impulsionar a lei, mas também tem efeito positivo sobre a ação moral, por interagir nos estritos limites da lei em busca da felicidade cultivada pela virtude, servindo assim de lastro tanto para o amor recíproco, quanto para a autoestima, que, por sua vez, é lastro imediato para ações morais.

Concluindo, como implicação à tradução, indicamos a manutenção exclusiva do termo amor de si (mesmo) racional para a Selbstliebe, quando se trata do caráter racional; e amor a si quando a Selbstliebe se trata apenas de nossa animalidade, reservando amor-próprio para os casos de Eigenliebe. Pois quando se confere dano ao amor-próprio (Eigenliebe), à presunção 
(Eigendünkel), obtém-se o amor de si mesmo racional (vernünftige Selbstliebe). O uso do termo Selbst engloba tanto uma noção velada de propriedade que o termo "eigen" carrega consigo, quanto indica a possibilidade de se lidar com o si mesmo, "selbst", que podemos atribuir mais facilmente a uma manifestação menos fenomênica e mais racional do ser humano; não obstante, é a partir da Metafísica dos costumes que Kant delineia claramente a dupla personalidade (zwei Selbst) do ser humano em sua unidade (numero idem), talvez uma possibilidade de interpretação da motivação que o levou a optar pela preferência pelo termo Selbstliebe ao invés de Eigenliebe depois do escrito de Eine Vorlesung über Ethik, algo que no entanto se apresenta como possibilidade de pesquisa futura por não fazer parte do escopo desta.

Ouse saber: o amor vence tudo - converge todas as inclinações e tem em sua natureza a disposição à moralidade. Basta aplicar-se primeiramente o respeito que tudo mais se moralizará por amor à lei. 
6

\section{Referências Bibliográficas}

Agamben, G. O que é um dispositivo \& O amigo. Chapecó: Argos, 2014

Araújo, R. Ampliação da imagem arquitetônica como sistema na história da filosofia in Kínesis, Vol. III, $n^{\circ}$ 06, Dezembro 2011

Arendt, H. A filosofia política de Kant. Rio de Janeiro: Relume Dumará Editora, 1994.

Aristóteles. De Anima. São Paulo: ed.34, 2006

Bittner, R. Máximas in Studia Kantiana volume 5 número 1. Revista da sociedade Kant brasileira, novembro de 2003.

Borges, M. de L. Amor. Rio de Janeiro: Jorge Zahar, Ed. 2004

Clausewitz, C. von. Da Guerra. $3^{\circ}$ Ed. Trad.: Maria Teresa Ramos. São Paulo: Editora WMF Martins Fontes, 2010

Chagas, F.C. 0 fato da razão e o sentimento moral enquanto disposição moral do ânimo in Studia Kantiana volume 11. Revista da sociedade Kant brasileira, dezembro de 2011.

Cordeiro, R. A antinomia do juízo teleológico e o princípio da causalidade natural in Studia Kantiana volume 5 número 1. Revista da sociedade Kant brasileira, novembro de 2003.

Dejeanne, S. Felicidade e dignidade de ser feliz: o sumo bem como ideal dialético da razão pura prática in Studia Kantiana volume 11. Revista da sociedade Kant brasileira, dezembro de 2011.

Eisler, R. Kant Lexikon. Hildesheim: Weidmannsche Verlagsbuchhandlung, 2008.

Ferry, L. Kant, Uma leitura das três críticas. Rio de Janeiro: Difel, 2012

Do Amor. Rio de Janeiro: Difel, 2013

F i e d l e r - Fe r r a r a, N. Quando o todo é mais sagaz do que a soma de suas partes. Scientiæ studia, v. 3, n. 2, p. 323-37. São Paulo: 2005.

Folscheid, D. \& Wunenburger, J-J. Metodologia filosófica. 4 Ed. Trad.: Paulo Neves. São Paulo: Editora WMF Martins Fontes, 2013

Kant, I. Antropologie in pragmatischer Hinsicht. Hamburg: Felix Meiner Verlag, 2000. 
Eine Vorlesung über Ethik. Herausgegeben von Gerd Gerhardt. Frankfurt am Main: Fischer Taschenbuch Verlag, 1990 Verlag, 1999.

Grundlegung zur Metaphysik der Sitten. Hamburg: Felix Meiner Kritik der Urteilskraft. Hamburg: Felix Meiner Verlag, 2006. Kritik der reinen Vernunft. Hamburg: Felix Meiner Verlag, 1993.

Kritik der praktischen Verrnunft. Hamburg: Felix Meiner Verlag, 1993. 1839 Schriften zur Philosophie der Religion. Leipzig: Nodes und Baumann,

Vorkritische Schriften bis 1768 - Teil 1. Frankfurt am Main: Suhrkamp Verlag, 1977 Verlag, 1977

Vorkritische Schriften bis 1768 - Teil 2. Frankfurt am Main: Suhrkamp

Vorlesung zur Moralphilosophie. Herausgegeben von Werner Stark. Berlin: de Gruyter, 2004

Was ist Aufklärung? Ausgewählte kleine Schriften. Hamburg: Felix Meiner Verlag, 1999.

Crítica da razão pura. $3^{\circ}$ Ed. Trad.: Fernando Costa Mattos. Petrópolis: Vozes, 2013.

Crítica da razão prática. $3^{\circ}$ Ed. Trad.: Valério Rohden. São Paulo: Editora WMF Martins Fontes, 2011

Crítica da razão prática. $3^{\circ}$ Ed. Trad.: Rodolfo Schaefer. São Paulo: Martin Claret, 2011

Crítica da faculdade do juízo. $3^{\circ}$ Ed. Trad.: Valério Rohden e Antônio Marques. Rio de Janeiro: Forense Universitária, 2012.

Escritos pré-críticos. São Paulo: Editora Unesp, 2005.

Lógica. Lisboa: Edições Texto \& Gráfica, 2009.

Metafísica dos costumes. Petrópolis: Vozes, 2013.

Metaphysische Anfangsgründe der Rechtslehre. Hamburg: Felix Meiner Verlag, 2009.

Metaphysische Anfangsgründe der Tugendlehre. Hamburg: Felix Meiner Verlag, 2008. 
Zum Ewigen Frieden. Rumo à paz perpétua. Edição bilingüe. Trad.: Heloísa Sarzana Pugliesi. São Paulo: Ícone, 2010.

Kneller, J. Kant e o poder da imaginação. São Paulo: Madras, 2010

Klaudat, A. Necessary sentimento and moral sensibility in Kant in Studia Kantiana volume 8. Revista da sociedade Kant brasileira, dezembro de 2010.

Hedonismo e Sumo Bem em Kant in Studia Kantiana volume 11. Revista da sociedade Kant brasileira, dezembro de 2011.

Langthaler, R. Kants Ethik als System der Zwecke. Berlin: de Gruyter, 1991.

Leite, F.T. 10 lições sobre Kant. Petrópolis: Vozes, 2007

Louzado, G.L. (org.) Ensaios sobre Kant. Porto Alegre: Linus, 2012

Marques, U.R.A. (org.) Kant e a biologia. São Paulo: Editora Barcarolla, 2012

Kant e a música. São Paulo: Editora Barcarolla, 2010

Pascal, G. Compreender Kant.Petrópolis: Vozes, 2011

Ricken, F. Kant über Selbstliebe: Anlage zum Guten oder Quelle alles Bösen? Philosophisches Jahrbuch 108 (2001) 245-258

Schönecker, D. O amor ao ser humano como disposição moral do ânimo no pensamento de Kant in Studia Kantiana volume 8. Revista da sociedade Kant brasileira, maio de 2009.

Kant, sobre a possibilidade de deveres para consigo mesmo (Tugendlehre 1-3) Kant in Studia Kantiana volume 8. Revista da sociedade Kant brasileira, dezembro de 2010.

Scruton, R. Kant. Porto Alegre: L\&PM Pocket, 2011.

Spinelli, M. Kant leitor de Epicuro Kant in Studia Kantiana volume 11. Revista da sociedade Kant brasileira, dezembro de 2011.

Vavsse. J-M. Vocabulário de Immanuel Kant. São Paulo: Editora WMF Martins 